WSRC-TR-2002-00460

\title{
HEEL REMOVAL ANALYSIS FOR MIXING PUMPS OF TANK 8
}

Si Young Lee and Richard A. Dimenna

Westinghouse Savannah River Company Savannah River Site Aiken, SC 29808

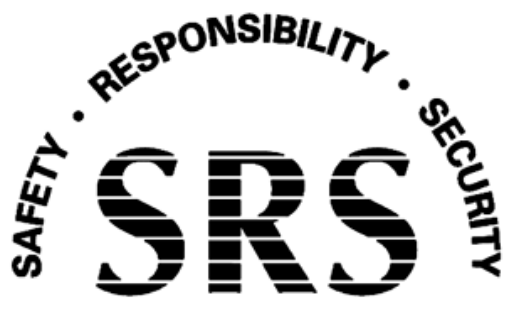




\section{HEEL REMOVAL ANALYSIS FOR MIXING PUMPS OF TANK 8}

SAVANNAH RIVER TECHNOLOGY CENTER

Si Young Lee and Richard A. Dimenna

September 2002

Westinghouse Savannah River Company

Savannah River Site

Aiken, SC 29808

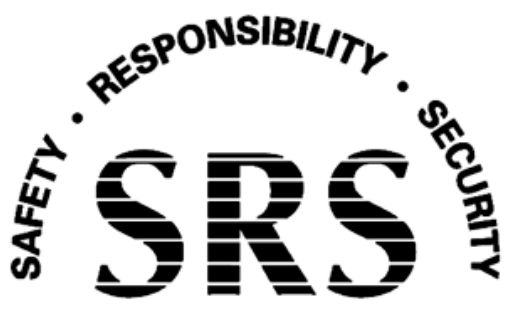

SAVANNAH RIVER SITE

Prepared for the U.S. Department of Energy under Contract No. DE-AC09-96SR18500

WSRC-TR-2002-00460 
(This Page Intentionally Left Blank) 
This document was prepared in conjunction with work accomplished under Contract No. DE-AC09-96SR18500 with the U. S. Department of Energy.

\section{DISCLAIMER}

This report was prepared as an account of work sponsored by an agency of the United States Government. Neither the United States Government nor any agency thereof, nor any of their employees, makes any warranty, express or implied, or assumes any legal liability or responsibility for the accuracy, completeness, or usefulness of any information, apparatus, product or process disclosed, or represents that its use would not infringe privately owned rights. Reference herein to any specific commercial product, process or service by trade name, trademark, manufacturer, or otherwise does not necessarily constitute or imply its endorsement, recommendation, or favoring by the United States Government or any agency thereof. The views and opinions of authors expressed herein do not necessarily state or reflect those of the United States Government or any agency thereof.

This report has been reproduced directly from the best available copy.

Available for sale to the public, in paper, from: U.S. Department of Commerce, National Technical Information Service, 5285 Port Royal Road, Springfield, VA 22161, phone: (800) 553-6847, fax: (703) 605-6900

email: orders@ntis.fedworld.gov

online ordering: http://www.ntis.gov/help/index.asp

Available electronically at http://www.osti.gov/bridge

Available for a processing fee to U.S. Department of Energy and its contractors, in paper, from: U.S. Department of Energy, Office of Scientific and Technical Information, P.O. Box 62, Oak Ridge, TN 37831-0062,

phone: (865)576-8401,

fax: (865)576-5728

email: $\underline{\text { reports@ adonis.osti.gov }}$ 
This page intentionally left blank 
WSRC-TR-2002-00460

(This Page Intentionally Left Blank) 
WSRC-TR-2002-00460

\section{Table of Contents}

List of Figures $\quad$ vii

$\begin{array}{ll}\text { List of Tables } & \text { ix }\end{array}$

Nomenclature $\quad$ xi

$\begin{array}{ll}\text { Abstract } & 1\end{array}$

1 Introduction 2

2. Modeling Approach and Analysis $\quad 7$

Characterization of the jet flow generated by a slurry pump of Tank $8 \ldots \ldots \ldots \ldots \ldots . . .7$

Assessment of Tank Flow Regime ............................................................. 8

Establishment of Flow Criterion for Quantitative Estimation of Sludge Heel

Removal

2.1 Tank 8 Model without Flow Obstructions (Model-I) ...................................... 15

2.2 Tank 8 Model with Flow Obstructions (Model-II) …....................................... 19

3. Results and Discussions 22

4. Summary and Conclusions 53

5. Recommendation $\quad 55$

$\begin{array}{ll}\text { 6. References } & 57\end{array}$ 
WSRC-TR-2002-00460

(This Page Intentionally Left Blank) 
WSRC-TR-2002-00460

\section{List of Figures}

Figure 1. Schematic of tank 8 layout with major flow obstructions of valve housing and four slurry mixing pumps.

Figure 2. Dimensions of sludge mound heels and mapping of four slurry mixing pumps.......4

Figure 3. Flow developments and evolutions of a jet flow along the discharge direction .......6

Figure 4. Schematic representation of solid concentration and velocity distributions for various flow regimes of solids-laden slurry $\left(\mathrm{V}_{\mathrm{c}}\right.$ is a minimum velocity to initiate the movement of particle from the deposit area as shown in Table 2.)...............10

Figure 5. Schematic flow boundary of a turbulent jet.

Figure 6. Three-dimensional modeling boundary for Model-I in the present analysis of the Tank 8 facility with four slurry pumps

Figure 6a. Hexahedral meshes on the $x-y$ computational domain of Model-I for a threedimensional CFD model of Tank 8 with four mixing pumps.

Figure 7. Schematic illustrations for the Model-II modeling boundary of Tank 8 with four slurry pumps including flow obstructions representing valve housing for cooling-coil flow control.

Figure 8. Three-dimensional CFD model of Tank 8 with four mixing pumps considering obstruction effects of valve housing consisting of 18 cooling pipes.

Figure 9. Flow velocity magnitudes along the centerline A'-A of Tank 8 at the dischage elevation of slurry pump for various numbers of operating pumps using the tank model with no internal flow obstructions (Model-I).

Figure 9a. Comparison of flow patterns at the nozzle exit plane between 26 in and 36 in pump elevations under the operating conditions of two slurry pumps.

Figure 10. Comparison of flow velocities at $20 \mathrm{in}$ elevation from the tank bottom between 26 in and 36 in pump elevations under the operating conditions of two slurry pumps.

Figure 11. Comparison of flow velocities at the nozzle exit plane between 26 in and 36 in pump elevations under the operating conditions of one slurry pump.

Figure 12. Comparison of flow patterns at the nozzle inlet plane between the models with and without flow obstructions under the operating conditions of two slurry pumps.

Figure 13. Comparison of flow velocities along the line A-A' between the models with and without flow obstructions under the operating conditions of two slurry pumps.

Figure 14. Comparison of flow patterns at the inlet nozzle plane between without and with flow obstructions under the operating conditions of four slurry pumps.

Figure 15. Comparison of flow velocities along the line A-A' between the models with and without flow obstructions under the operating conditions of four slurry pumps.

Figure 16. Comparison of flow patterns at the nozzle exit plane for the 130 in and 40 in tank levels under the operating conditions of two slurry pumps.

Figure 17. Comparison of flow velocities along the line A-A' at the nozzle inlet plane between the 130 in and 40 in tank levels under the operating conditions of two slurry pumps.

Figure 17a. Transient flow velocities along the line A'-A at the nozzle inlet plane using Model-I with two pumps running under the reference operating conditions.

Figure 18. Transient flow evolutions at the nozzle exit plane under the operating conditions of two slurry pumps (pump no. 5 and 8 ) 
Figure 18. Transient flow evolutions at the nozzle exit plane under the operating conditions of two slurry pumps (pump no. 5 and 8 ) (continued).

Figure 19. Flow velocity magnitude along the line A'-A and pump ECR estimation under three pump operations (pump no. 1, no. 3, and no. 5)

Figure 20. Comparison of flow patterns at the nozzle inlet plane between two different pump speeds (1800 rpm and $1600 \mathrm{rpm}$ ) using the models with flow obstructions under the operating conditions of two slurry pumps.

Figure 21. Comparison of flow velocities along the line A-A' between two different pump speeds (1800 rpm and $1600 \mathrm{rpm}$ ) using the models with flow obstructions under the operating conditions of two slurry pumps.

Figure 22. Flow patterns for the pump orientation of one pump operation in association with effectiveness of sludge removal located at the corner of valve housing (Case-A: pump no. 8 operation)

Figure 23. Flow patterns for the pump orientation of two-pump operation in association with effectiveness of sludge removal located at the corner of valve housing (Case-B: pump no. 5 and no. 8 operations)

Figure 24. Flow patterns for the pump orientation of two-pump operation in association with effectiveness of sludge removal located at the corner of valve housing (Case-C: pump no. 1 and no. 3 operations).

Figure 25. Flow patterns for the pump orientation of three-pump operation in association with effectiveness of sludge removal located at the corner of valve housing (Case-D: pump no. 1, no. 5, and no. 8 operations)

Figure 26. Velocity contour plot for the four-pump operation in association with effectiveness of sludge removal located at the corner of valve housing (CaseE: pump no. 1 , no. 3 , no. 5 , and no. 8 operations)

Figure 26a. Flow patterns for the four-pump operation in association with effectiveness of sludge removal located at the corner of valve housing (Case-E: pump no. 1, no. 3 , no. 5 , and no. 8 operations)

Figure 27. Flow velocity results along the line A-B near the sludge heel regions using selected numbers of operating pumps and aiming nozzle directions for the reference operating conditions (1800 rpm)

Figure 28. Flow velocity results along the line A-B near the sludge heel regions using selected numbers of operating pumps and aiming nozzle directions for the lower pump speed (1600 rpm)

Figure 29. Flow velocity results along the line A-B near the sludge heel regions using selected numbers of operating pumps and aiming nozzle directions for the reference operating conditions (2000 rpm) 
WSRC-TR-2002-00460

\section{List of Tables}

Table 1. Specifications of Tank 8 slurry pump used for the present analysis.

Table 2. inimum velocities of particle suspension and transport/removal for the various particle sizes in water (particle density=2.0SG)

Table 3. CFD modeling approaches taken for the present analysis.

Table 4. Reference design and operating conditions of Tank 8 used for the present analysis

Table 5. omparison of operational times to reach steady-state mixing flow patterns for three different situations

Table 6. Pump nozzle locations for efficient operation of sludge heel removal under the reference operating conditions shown in Table 4

Table 7. Sensitivity results for different fluid properties in the Tank 8 model in terms of maximum clearing distance (MCD) 
WSRC-TR-2002-00460

(This Page Intentionally Left Blank) 
WSRC-TR-2002-00460

\section{Nomenclature}

$A=\operatorname{area}\left(\mathrm{ft}^{2}\right.$ or $\left.\mathrm{m}^{2}\right)$

$\mathrm{C}=$ constant in eq. (9) (--)

$\mathrm{C}_{\mathrm{p}}=$ specific heat $(\mathrm{J} / \mathrm{kg} \mathrm{K})$

$\mathrm{d}=$ branch diameter or solid particle size in slurry (ft or $\mathrm{m}$ )

$\mathrm{D}=$ main pipe diameter ( $\mathrm{ft}$ or $\mathrm{m}$ )

$\mathrm{f}=$ empirical factor

$\mathrm{F}=$ force $(\mathrm{N})$

$\mathrm{g}=$ gravity $\left(\mathrm{m} / \mathrm{sec}^{2}\right)$

$\mathrm{H}=$ tank liquid level ( $\mathrm{ft}$ or $\mathrm{m}$ )

$\mathrm{I}=$ turbulence intensity (--)

$\mathrm{k}=$ constant in eq. (2) (--), or thermal conductivity $(\mathrm{W} / \mathrm{m} \mathrm{K})$

$\mathrm{K}=$ constant in eq. (3)

$\mathrm{m}=$ particle mass flowrate $(\mathrm{kg} / \mathrm{sec})$

$\mathrm{P}=$ pressure $(\mathrm{Pa})$

$\operatorname{Pr}=$ Prandtl number, $\mu \mathrm{C}_{\mathrm{p}} / \mathrm{k},(--)$

$r=$ radial distance perpendicular to the jet axis (ft or $\mathrm{m}$ )

$\mathrm{R}=$ curvature radius of elbow or droplet radius (ft or $\mathrm{m}$ )

$R e=$ Reynolds number, $d \rho u / \mu$ or $d \rho U / \mu$

$\mathrm{t}=$ time (second)

$\mathrm{U}=$ slurry velocity at nozzle exit (ft/sec or $\mathrm{m} / \mathrm{sec}$ )

$\mathrm{u}=$ component velocity in $\mathrm{x}$-direction (ft/sec or $\mathrm{m} / \mathrm{sec}$ )

$\mathrm{u}^{\prime}=$ local turbulent velocity fluctuation in $\mathrm{x}$-direction ( $\mathrm{ft} / \mathrm{sec}$ or $\mathrm{m} / \mathrm{sec}$ )

$\mathrm{v}=$ local flow velocity or component velocity in $\mathrm{y}$-direction (ft/sec or $\mathrm{m} / \mathrm{sec}$ )

$v^{\prime}=$ local turbulent velocity fluctuation in $\mathrm{y}$-direction $(\mathrm{ft} / \mathrm{sec}$ or $\mathrm{m} / \mathrm{sec}$ )

$\mathrm{V}=$ average velocity magnitude ( $\mathrm{ft} / \mathrm{sec}$ or $\mathrm{m} / \mathrm{sec}$ )

$\mathrm{w}=$ component velocity in z-direction ( $\mathrm{ft} / \mathrm{sec}$ or $\mathrm{m} / \mathrm{sec}$ )

$w^{\prime}=$ local turbulent velocity fluctuation in z-direction ( $\mathrm{ft} / \mathrm{sec}$ or $\mathrm{m} / \mathrm{sec}$ )

$\mathrm{x}=$ local position along the $\mathrm{x}$-direction under Cartesian coordinate system ( $\mathrm{ft}$ or $\mathrm{m}$ )

$\mathrm{y}=$ local position along the $\mathrm{y}$-direction under Cartesian coordinate system ( $\mathrm{ft}$ or $\mathrm{m}$ )

$\mathrm{z}=$ local position along the $\mathrm{y}$-direction under Cartesian coordinate system ( $\mathrm{ft}$ or $\mathrm{m}$ ) 


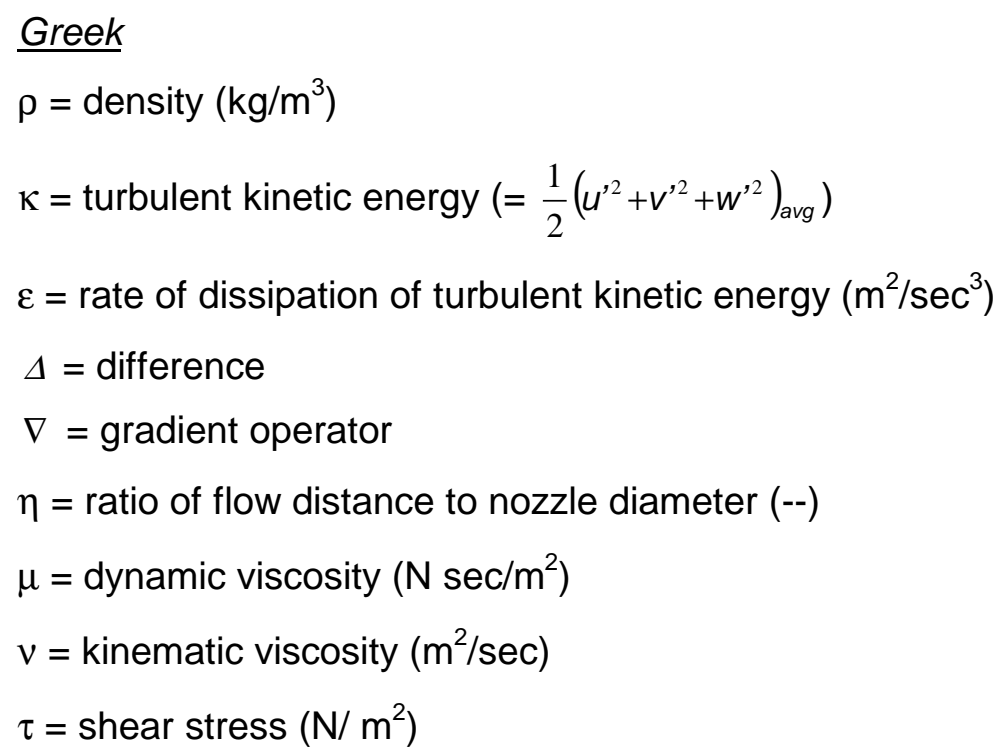




\section{Abstract}

Computational fluid dynamics methods were used to recommend a slurry pump operational strategy for sludge heel removal in Tank 8. Flow patterns calculated by the model were used to evaluate the performance of various combinations of operating pumps and their orientation. The models focused on removal of the sludge heel located at the east side of Tank 8 using the four existing slurry pumps. The models and calculations were based on prototypic tank geometry and expected normal operating conditions as defined by Waste Removal Closure (WRC) Engineering.

Computational fluid dynamics models of Tank 8 with different operating conditions were developed using the FLUENTTM code. The flow calculations were compared with previous experimental results to validate the maximum pump clearance distance for waste removal operations in Tank 8. The results were used to assess the efficiency of sludge suspension and removal operations in the $75 \mathrm{ft}$ tank. The models employed a three-dimensional approach, a two-equation turbulence model, and an approximate representation of flow obstructions. The calculated local velocity was used as a measure of sludge removal and mixing capability.

The calculated results demonstrated that for pump speeds higher than $1800 \mathrm{rpm}$ and at a 130 inch liquid level, a recommended orientation of the slurry pumps could be provided, based on a minimum sludge suspension velocity of $2.27 \mathrm{ft} / \mathrm{sec}$. Further results showed that the time to reach a steady-state flow pattern was affected by both the tank level and the pump speed. Sensitivity studies showed that for a given pump speed, a higher tank level and a lower pump nozzle elevation would result in better performance in suspending and removing the sludge. The results also showed that the presence of flow obstructions were advantageous for certain pump orientations. 
Page: $\quad 2$ of 58

\section{Introduction}

Tank 8 is a 0.75 million-gallon, single-wall, Type I waste tank located in the F-Tank Farm area. The tank was placed into service as a receiver of high heat wastes. The tank is a $75 \mathrm{ft}$ diameter, flat-bottomed, cylindrical carbon steel tank with a height of about $24.5 \mathrm{ft}$. There are cooling coils, a valve housing to control coolant flow in the cooling coils, and structural supports internal to the tank. The waste in the tank consists of salt and sludge. The salt was removed by dissolution in water and transferred to other tanks for storage. The remaining sludge mound settled near the bottom, east wall of the tank will then be hydraulically mobilized and transferred to other tanks.

To suspend and mobilize the sludge mound, water will be added to Tank 8 as a slurry medium. Tank 8 has four slurry pumps manufactured by the Lawrence Company [1] available for sludge removal operations. Each pump has a bottom suction with two opposing discharge nozzles, $1.5 \mathrm{in}$. in diameter. The pump is normally submerged to approximately the level of the sludge, allowing a recirculating mixture of sludge and water to serve as the feed flow. The pump nozzle can not be placed lower than about 26 inches above the tank bottom [1]. All pumps are located at a $16.5 \mathrm{ft}$ radial distance from the tank wall as shown schematically in Fig. 1. Each pump can rotate between 0.2 and $0.5 \mathrm{rpm}$ using a variable frequency drive. The cleaning pattern generated on the tank bottom defines the effective cleaning radius (ECR) when the pump rotates. The ECR has been one of the measures or indicators of the cleaning ability of a mixing pump. After the mixer suspends the sludge, waste transfers from Tank 8 to another tank will be performed. Detailed design information for the slurry pump is shown in Table 1.

In previous work [3], a three-dimensional computational fluid dynamics (CFD) model for a prototypic tank was developed and benchmarked against TNX test data. The test data were obtained from a mixing experiment conducted in a full tank mockup in the TNX area. The test tank was $85 \mathrm{ft}$ in diameter and $8 \mathrm{ft}$ high. The advanced mixing pump of Tank 18, which had similar design characteristics to the Tank 8 mixing pumps, was used to suspend a kaolin clay slurry in the tank. Its long shaft was enclosed in a 16 " nominal pipe diameter casing. It was located $16 \mathrm{ft}$ from the tank wall with a discharge elevation 27 in above the tank bottom. Kaolin clay slurries were used to simulate the actual sludge in the waste tanks [3].

The primary objective of the present work is to provide a recommended operational strategy for sludge heel removal. The flow patterns calculated by the model will be used to evaluate the capabilities of the slurry mixers under various combinations of number of operating pumps and their nozzle discharge orientation. A schematic layout and dimensions of the sludge mound heel located at the east corner of the tank are shown in Fig. 2. Figure 3 shows the typical flow development and evolution of a jet flow discharged by a slurry mixer obtained from previous modeling results [3] and literature information [10].

The analysis results will be used to evaluate hydraulic cleaning capabilities for waste removal. This information will also assist in the operating plan for the Tank 8 waste removal and in identifying special operation requirements for the suspension and removal of the tank sludge heel. 


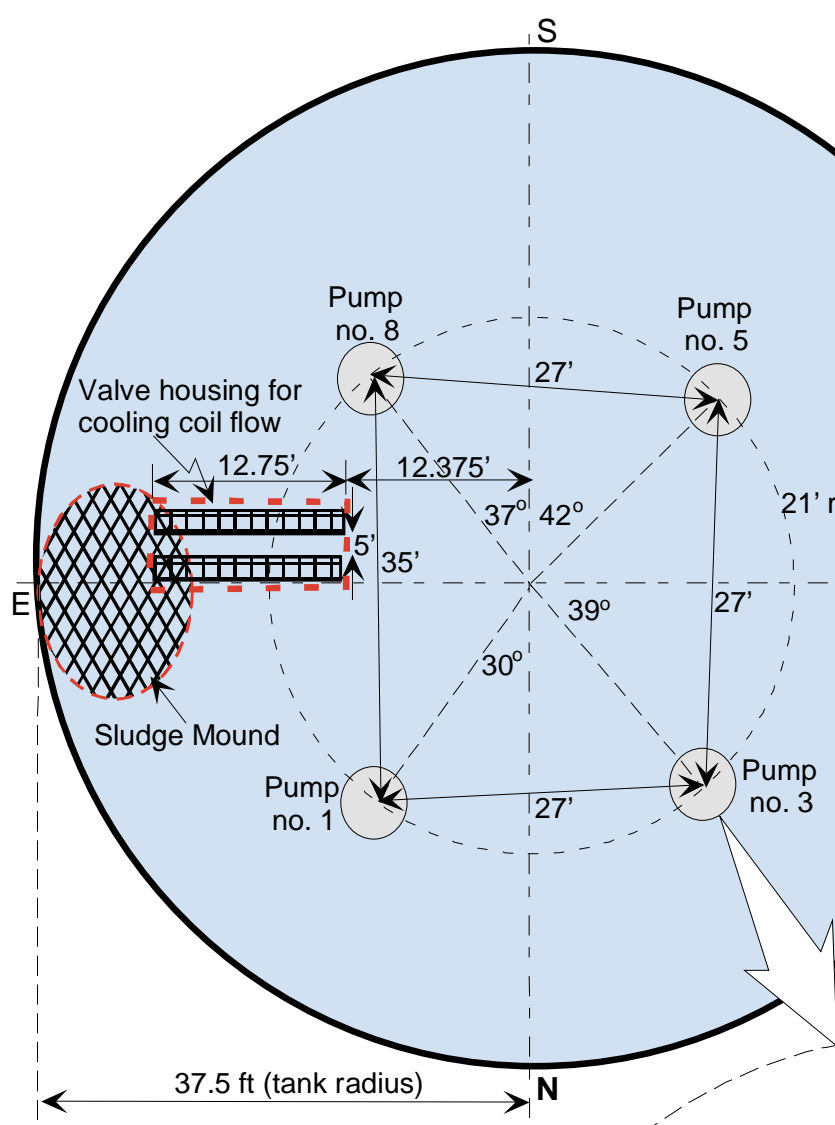

(Top view of Tank 8)

$75^{\prime}$ tank wall

poundary

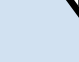

(1)

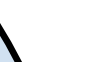

(130 in or 40in)

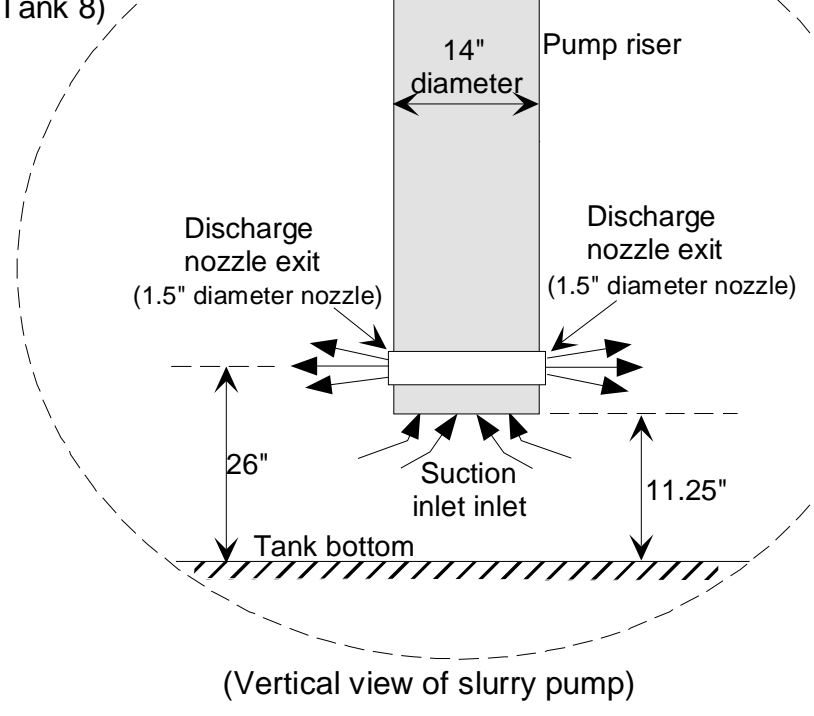

Figure 1. Schematic of tank 8 layout with major flow obstructions of valve housing and four slurry mixing pumps. 
Report: WSRC-TR-2002-00460

Date: $\quad 01 / 10 / 03$

\section{Page: $\quad 4$ of 58}

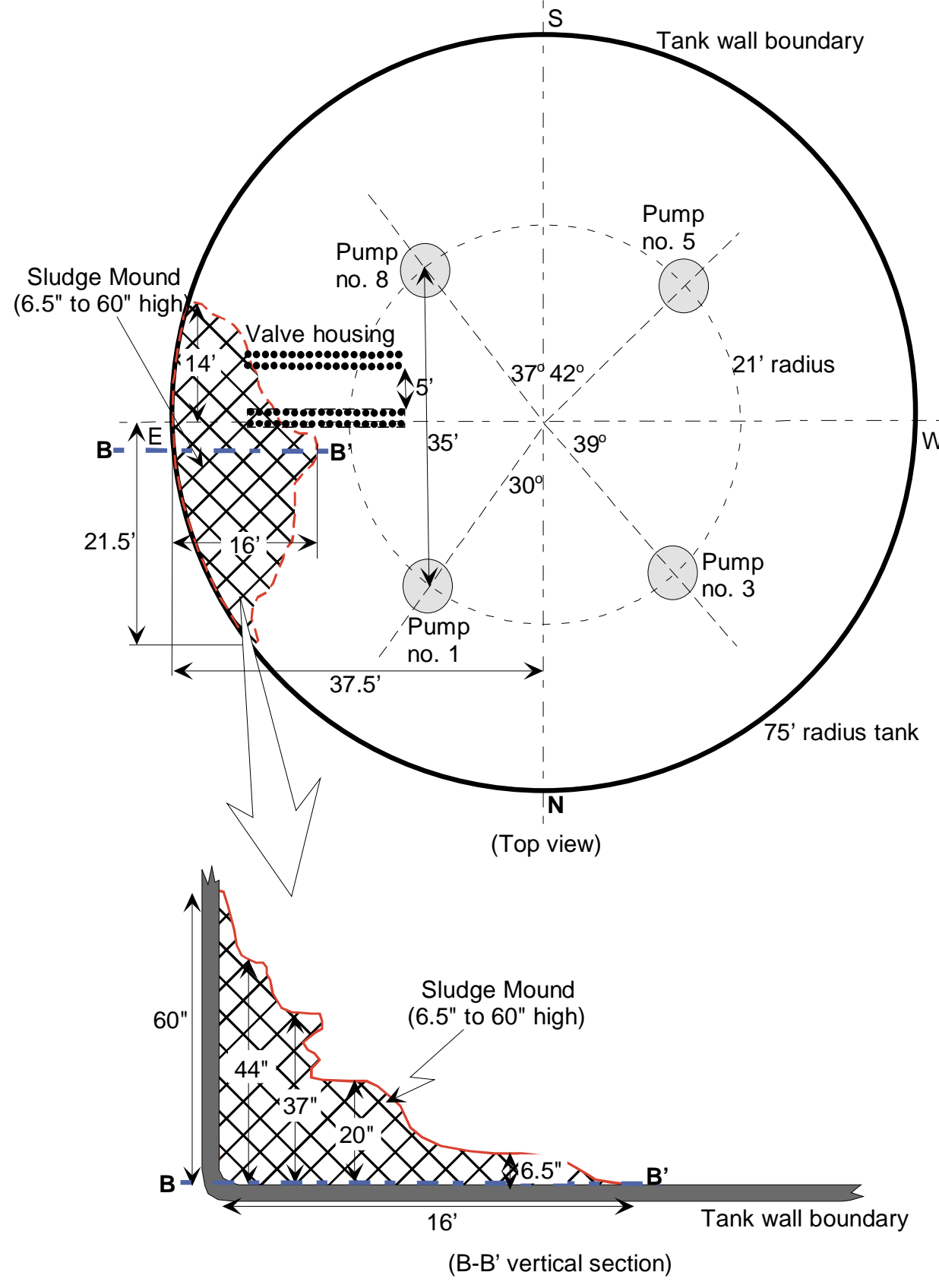

Figure 2. Dimensions of sludge mound heels and mapping of four slurry mixing pumps. 
Table 1. Specifications of Tank 8 slurry pump used for the present analysis.

\begin{tabular}{|c|c|}
\hline Design Parameters & Slurry Pump \\
\hline Horsepower, hp & 150 \\
\hline Pump casing diameter, inches & 22.5 \\
\hline Pump column diameter, inches & 14 \\
\hline $\begin{array}{c}\text { Number of discharge nozzles } \\
\text { (flow directions) }\end{array}$ & $2\left(180^{\circ}\right.$ apart and opposite flow direction) \\
\hline $\begin{array}{c}\text { Nozzle diameter, inches } \\
\text { Pump suction location }\end{array}$ & 1.5 \\
\hline Suction diameter, inches & Bottom of pump \\
\hline Flowrate per nozzle, gpm & $600^{*}$ \\
\hline $\begin{array}{c}\text { Flow velocity at pump } \\
\text { discharge nozzle, ft/sec }\end{array}$ & About 109 (1200 gpm at $1800 \mathrm{rpm})^{*}$ \\
\cline { 2 - 2 } & About $99.6(1097 \mathrm{gpm}$ at $1600 \mathrm{rpm})$ \\
\hline
\end{tabular}

Note: Reference operating conditions 


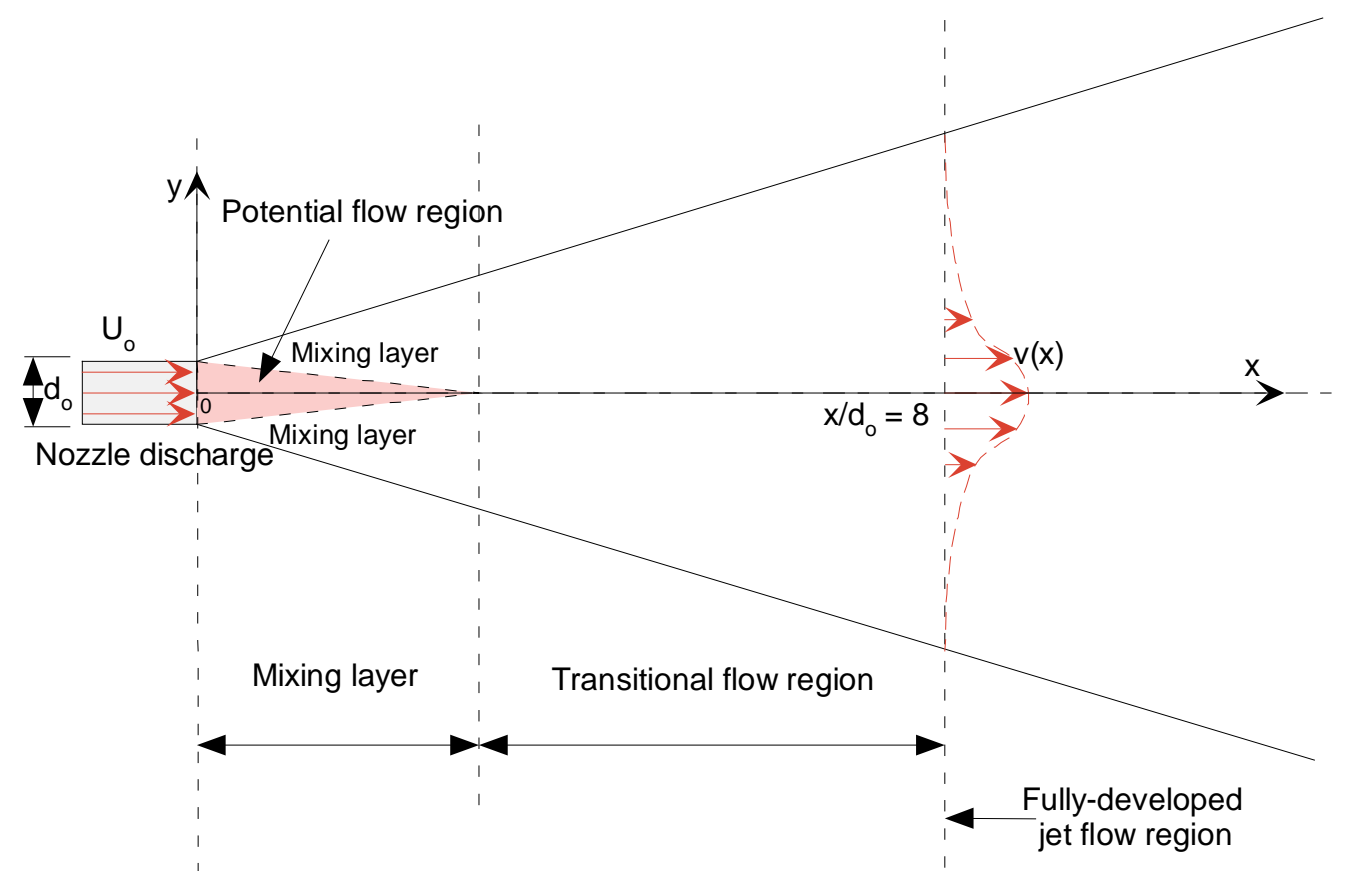

(Two-dimensional jet flow)

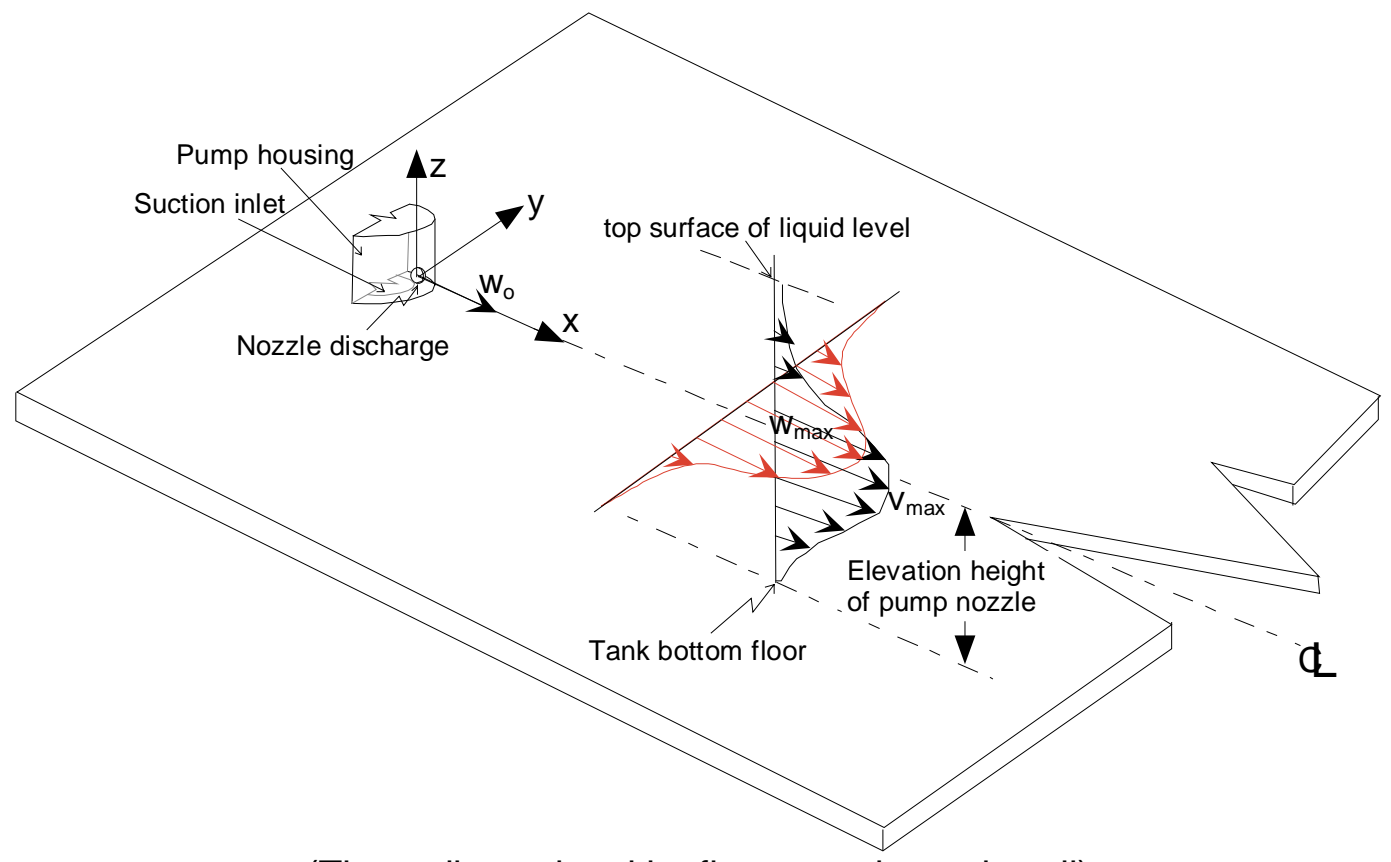

(Three-dimensional jet flow near the tank wall)

Figure 3. Flow development and evolution of a jet flow along the discharge direction 


\section{Modeling Approach and Analysis}

In previous analyses [3], a three-dimensional CFD approach was used to calculate flow velocity distributions for Tank 18 . The calculation results were benchmarked against both TNX and literature data. The model predictions were in good agreement with test data. The same finite volume CFD code, FLUENT [6], was used here to perform the Tank 8 analysis. A prototypic geometry was modeled with a non-orthogonal mesh.

The decay rate of the jet axial velocity and the evolution of flow patterns are potentially important phenomena affecting sludge suspension and removal operations. They result from the interaction of the submerged turbulent jet with the tank wall, internal solid obstructions, and free surface. The ability to shear the sludge layer is also directly related to the local velocity. Hence, flow velocity of the discharge jet is considered one of the key parameters governing the degree of sludge suspension and turbulent mixing for the present work.

The present models consider flow obstructions such as key pump support structures and the valve housing, but they do not model the presence of the sludge mound. Modeling a moving solid boundary as the sludge heel erodes is beyond the capability of the present code. Instead, the flow velocity in the vicinity of the sludge mound is used as an indicator of the ability of the flow to suspend sludge and remove the heel.

Before establishing the flow criterion for a quantitative estimation of sludge heel removal, decay characteristics of a submerged jet flow and assessment of the slurry flow regime need to be discussed briefly using literature information and our previous analyses. Detailed discussions are provided below.

\section{Characterization of the jet flow generated by a slurry pump of Tank 8}

When a turbulent jet of fluid is discharged from a nozzle with a diameter $d_{0}$, it both entrains fluid and expands as shown in Fig. 3 [7, 10,11]. Most mixing action and entrainment takes place in the region of fully-developed flow which begins at a distance of approximately eight nozzle diameters from the discharge plane. The non-dimensional velocity distribution $\varphi_{v}$ along the jet axis of this region for a homogeneous fluid jet is given by [10]

$$
\varphi_{v}=\left(\frac{v(x)}{U_{o}}\right)=C_{o}\left[\frac{x}{d_{o}}\right]^{-1}=C_{o} \eta^{-1}
$$

In eq. (1), $C_{o}$ is a constant determined by the turbulence characteristics of the jet, $U_{o}$ the nozzle exit velocity, $v(x)$ the local velocity at a point $x$, and $x$ the distance from nozzle. Abramovich (1963) correlated the experimental data for a free turbulent jet submerged in fluid using the non-dimensional form provided by eq. (1). From his work, the proportional constant $C_{o}$ in eq. (1) was determined to be 6.3158 .

Equation (1) shows that the velocity at any point in the region of established flow is directly proportional to the product, $d_{o} U_{o}$. Thus, the one-dimensional entraining distance corresponding to the minimum entrainment velocity can be estimated theoretically when nozzle size and pumping flowrate are provided. 
Page: $\quad 8$ of 58

However, the fluid region for the present work has both a solid boundary and a free surface boundary as the jet expands into the downstream region and then the flow recirculates in the tank. The spreading fluid is retarded by the frictional resistance of the wall. The inner part of the flow may be expected to show a certain structural similarity to a boundary layer, whereas entrainment of quiescent fluid occurs near the outer edge of the flow, which accordingly is likely to resemble a free jet in character.

When a solid structure or wall surface is present near the jet nozzle, the jet flow will feel a three-dimensional interaction from the wall boundary and free surface. The literature [5] has shown that the flow region of the jet up to 40 nozzle diameters, $\eta=40$ in eq. (1), is not affected by the presence or absence of a wall near the nozzle.

\section{Assessment of Tank Flow Regime}

Average flow velocity, particle size and density, and slurry flow regime are key important parameters in determining the transport patterns of particles in a slurry [13], which are closely related to the erosion phenomena. In this case, the critical velocity is defined as the minimum velocity that can initiate the movement of the solids deposited near the bottom of the tank. Graf [13] correlated the critical velocity $V_{c}$ empirically in terms of geometrical dimensions and the ratio of particle to fluid densities using data available in the literature.

$$
V_{c}=\left(\frac{d}{H}\right)^{-0.1} \sqrt{2.5 g d\left(\frac{\rho_{s}}{\rho_{f}}-1\right)}
$$

In eq. (2) $d$ and $H$ are the particle diameter and tank liquid level, respectively. As seen in Fig. 4, when the average flow velocity is much larger than the critical velocity, $V_{c}$, the literature results show that solid particles in a continuous flow field are homogeneously distributed[13]. When the flow velocity required for sludge transport and removal is exceeded, the solid-laden flow can be treated as a homogeneous fluid. Thus, once sludge particles are suspended by the continuous flow, the conditions of the first of the three typical slurry flow fields shown in Fig. 2 are satisfied. Thus, the present flow calculations are based on a homogeneous single-phase fluid flow. The flow criterion for sludge removal will be established next. 
Table 2. Minimum velocities of particle suspension and transport/removal for the various particle sizes in water (particle density=2.0SG)

\begin{tabular}{|c|c|c|c|}
\hline $\begin{array}{c}\text { Tank } \\
\text { level } \\
\text { (inches) }\end{array}$ & $\begin{array}{l}\text { Particle } \\
\text { size } \\
\text { (microns) }\end{array}$ & $\begin{array}{c}\text { Minimum velocity }\left(V_{c}\right) \text { required } \\
\text { to initiate movement of particle } \\
\text { deposited from horizontal wall } \\
\text { surface computed by eq. (2) } \\
(\mathrm{ft} / \mathrm{sec})\end{array}$ & $\begin{array}{l}\text { Typical minimum velocity } \\
\text { used for particle suspension } \\
\text { and transport for Tank } 8 \\
\text { sludge removal operations } \\
\text { (ft/sec) }\end{array}$ \\
\hline \multirow{3}{*}{130} & 1 & 0.073 & \multirow{6}{*}{$\begin{array}{c}2.27^{\star} \text { (for sludge removal) } \\
\text { [Refs. 2, 3] }\end{array}$} \\
\hline & 10 & 0.183 & \\
\hline & 20 & 0.242 & \\
\hline \multirow{3}{*}{40} & 1 & 0.065 & \\
\hline & 10 & 0.163 & \\
\hline & 20 & 0.215 & \\
\hline
\end{tabular}

Note: * The average velocity used in this analysis, $2.27 \mathrm{ft} / \mathrm{sec}$, is much larger than the minimum critical velocity $\left(V_{c}\right)$ to initiate movement of particle deposited at surface. This case corresponds to Case a in Fig. 4. 
Page: $\quad 10$ of 58

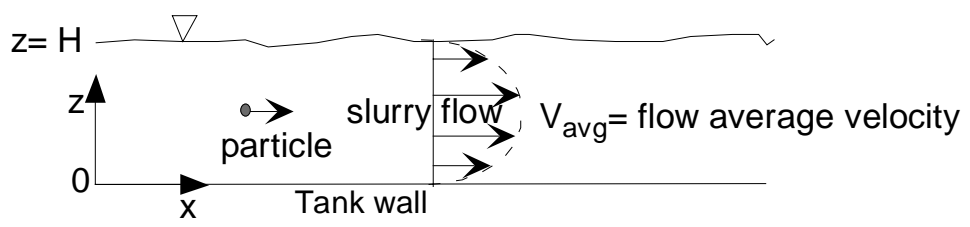

Case a: For homogeneous flow regime $\left(\mathrm{V}_{\mathrm{avg}}>>\mathrm{V}_{\mathrm{C}}\right.$ : the present case $)$
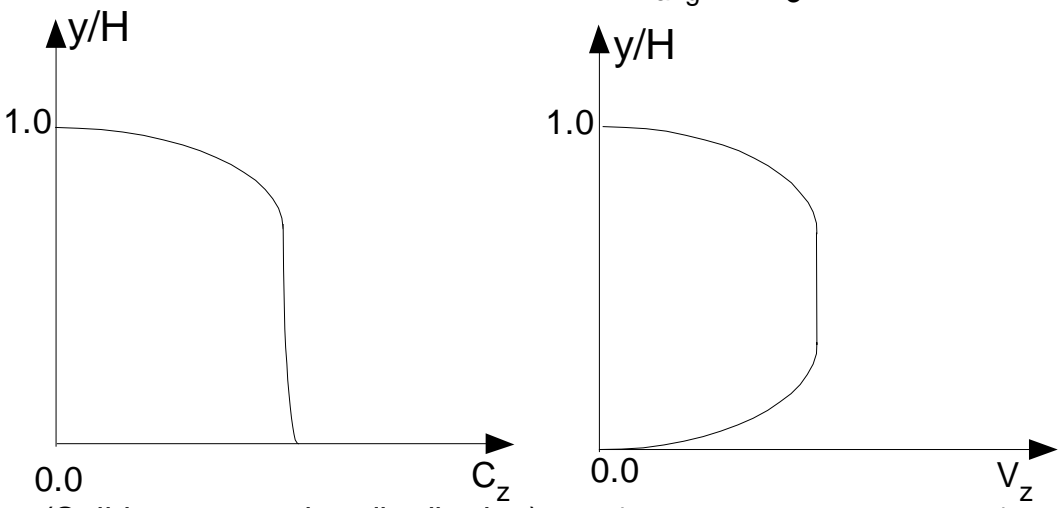

(Solid concentration distribution)

(Flow velocity distribution)

Case b: For non-homogeneous flow regime $\left(\mathrm{V}_{\mathrm{avg}} \sim \mathrm{V}_{\mathrm{C}}\right)$
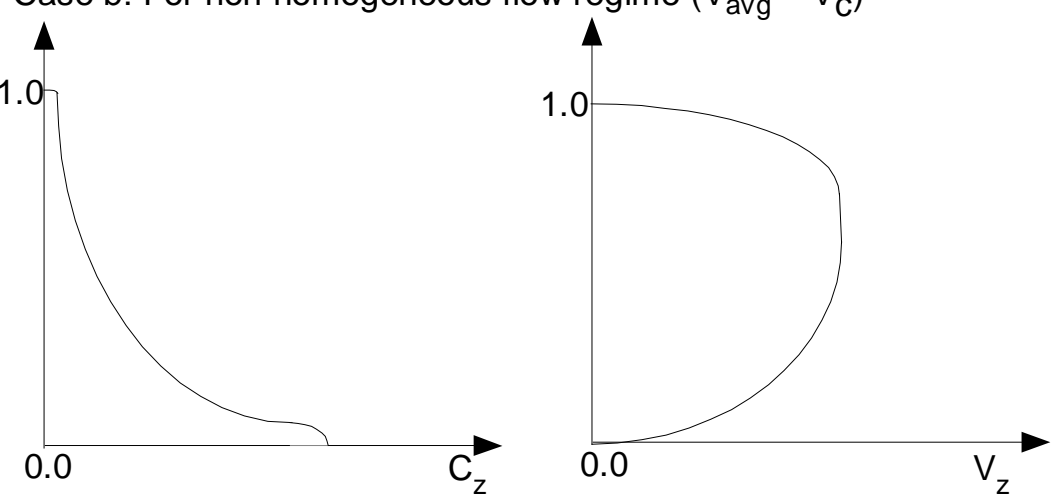

(Solid concentration distribution)

(Flow velocity distribution)

Case c: For non-homogeneous flow regime with solid particle deposit $\left(\mathrm{V}_{\mathrm{avg}}<\mathrm{V}_{\mathrm{C}}\right)$

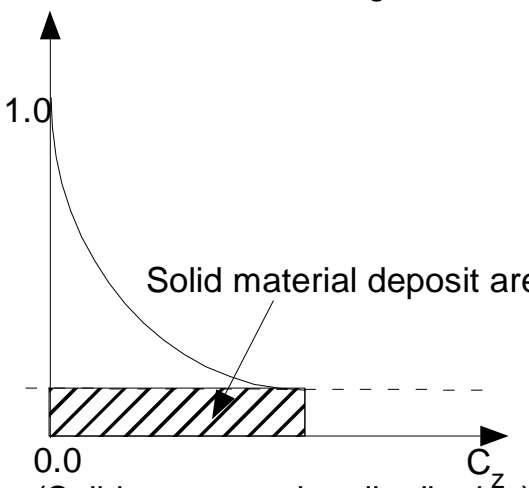

(Solid concentration distribution)

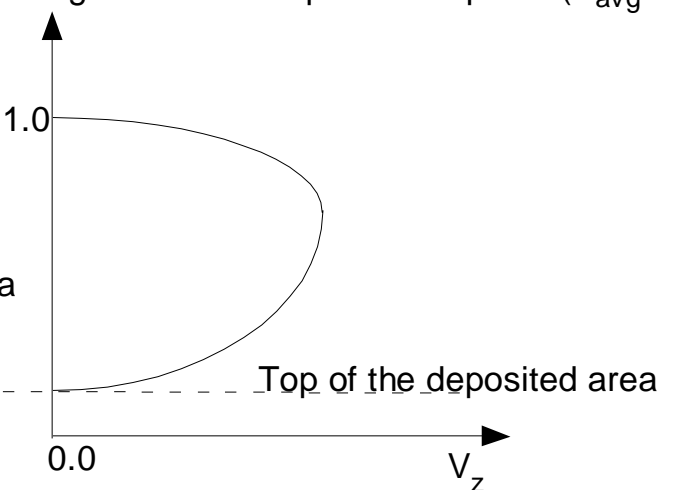

(Flow velocity distribution) $\mathrm{z}$

Figure 4. Schematic representation of solid concentration and velocity distributions for various flow regimes of solids-laden slurry $\left(\mathrm{V}_{\mathrm{c}}\right.$ is a minimum velocity to initiate the movement of particle from the deposit area as shown in Table 2.). 


\section{Establishment of Flow Criterion for Quantitative Estimation of Sludge Heel} Removal

The flow patterns calculated in the Tank 8 analysis can be used to estimate the effectiveness of sludge removal operations and the amount of the sludge mound that would be left behind. The flow calculations will be assessed for the sludge removal in terms of the ECR of the pump. Observations and measurements from Tank 8 [2] were used to quantify the ECR and to interpret the mixing performance calculations for Tank 18 [3].

The dissipation of a turbulent jet flow through a nozzle is shown schematically in Fig. 5 . Using the notation provided in the figure, the axial velocity distribution along the jet axis is described as follows:

$$
v(x, r=0)=v_{c}(x)=K\left(\frac{U_{o} d_{o}}{x}\right)
$$

Since the pump discharge flow is affected by the bottom of the tank, the constant $K$ is evaluated from the Tank 18 calculations rather than classical free jet theory. It was found to be 4.874 [3]. The maximum axial velocity at any axial position $x$ can be estimated using eq. (3). The radial flow distribution, $v_{r}$, at a given axial position, $x=x_{r}$, is given in terms of radial position $r$ perpendicular to the jet axis by [16].

$$
\log \left(\frac{v_{c r}}{v_{r}}\right)=K_{r}\left(\frac{r}{x_{r}}\right)^{2}
$$

Results from Reference 2 showed $K_{r}$ to be 9.5. Then eq. (4) becomes

$$
\log \left(\frac{v_{c r}}{v_{\text {cone }}}\right)=9.5\left(\frac{r_{c}}{x_{r}}\right)^{2}
$$

The ECR is defined as the distance from the nozzle exit to the point along the jet axis at which the local velocity is just equal to the minimum velocity needed to suspend sludge. This velocity is identified as $v_{E C R}$. This same magnitude of velocity can be found at an off-axis location and identified with $v_{\text {cone }}$ as shown in Fig. 5. Equating these two velocities and using eq. (3) gives the suspension velocity,

$$
v_{E C R}=v_{\text {cone }}=K\left(\frac{U_{o} d_{o}}{E C R}\right) .
$$

From eqs. (3) and (6), the ratio of the axial velocity $v_{c r}$ at $x=x_{r}$ to the ECR velocity $v_{E C R}$ can be found.

$$
\left(\frac{v_{c r}}{v_{E C R}}\right)=\left(\frac{v_{c r}}{v_{\text {cone }}}\right)=\left(\frac{E C R}{x_{r}}\right) .
$$

From eqs. (5) and (7), the velocity terms can be eliminated. That is,

$$
\log \left(\frac{E C R}{x_{r}}\right)=9.5\left(\frac{r_{c}}{x_{r}}\right)^{2}
$$




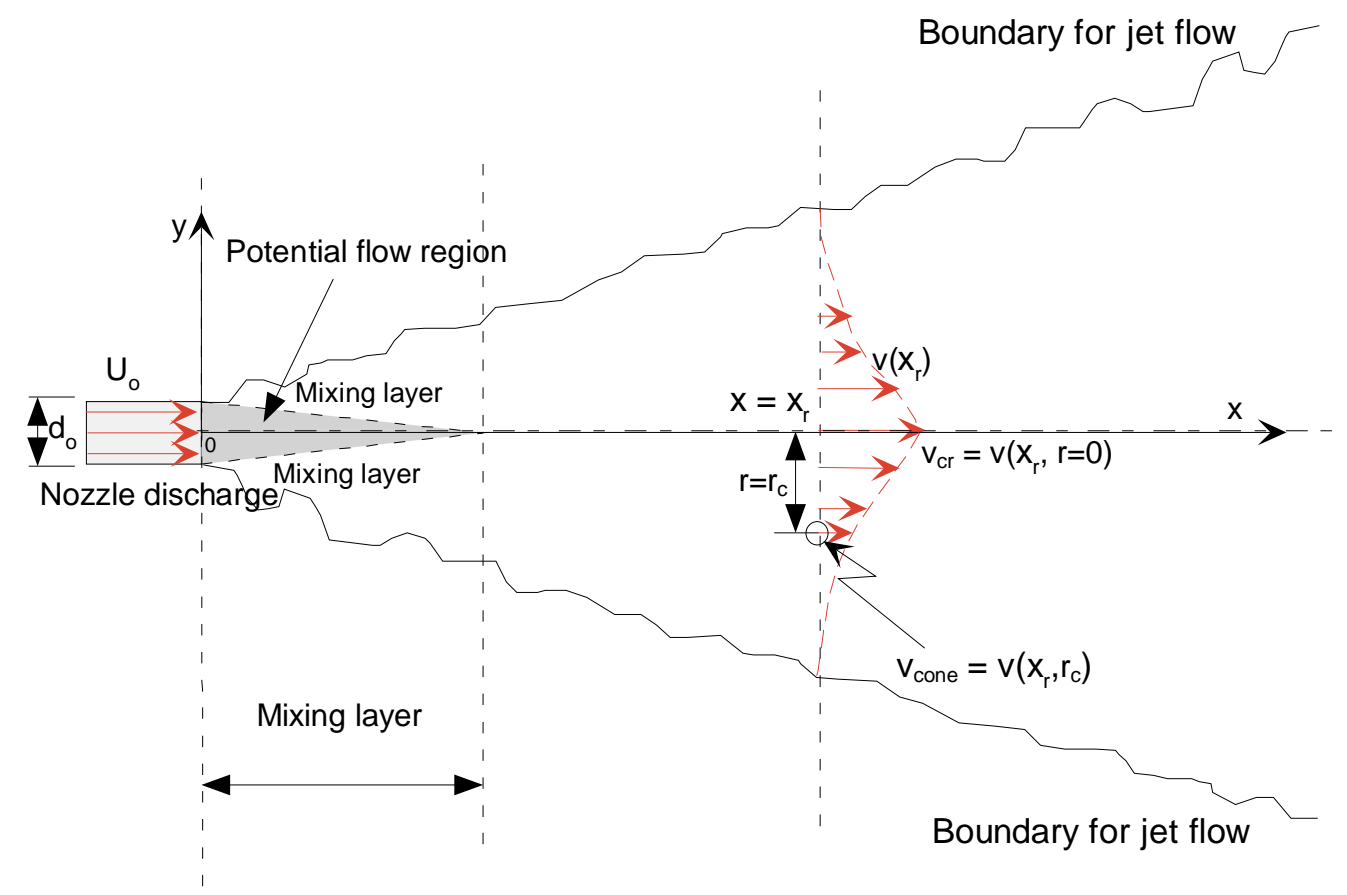

Figure 5. Schematic flow boundary of a turbulent jet

Eq. (8) can be used to relate two measured values from the Tank 8 report [2], the disturbance depth, $r_{c}$, and the ECR. The disturbance depth is the depth to which the sludge layer was eroded by the horizontal jet. When these values are inserted in eq. (8), the axial location, $x_{r}$, where the sludge is suspended and removed from the sludge hill can be calculated. The Tank 8 report lists the ECR and the disturbance depth $r_{c}$ as $26 \mathrm{ft}$ and $28 \mathrm{in}$, respectively, which gives a value of $x_{r}=18 \mathrm{ft}$.

The sludge suspension velocity can be found from eq. (7) if the axial velocity at $x_{r}$ is known. The axial velocity at the $18 \mathrm{ft}$ distance is given by eq. (3). The suspension velocity of the sludge was found to be $2.27 \mathrm{ft} / \mathrm{sec}$ [3]. This value is consistent with the experimental observations in Tank 8 [2]. Therefore, the present work will use this velocity as the flow criterion in providing a recommended operational strategy for Tank 8 heel removal.

It is important to recognize that the suspension velocity determined from the Tank 8 observations is not a precise measure, but is in reality affected by the uncertainty in evaluating the ECR. The value of $2.27 \mathrm{ft} / \mathrm{sec}$ is used in this report as a nominal criterion against which calculated flow patterns can be assessed. It should not be interpreted as having three-digit accuracy, but rather as being an appropriate evaluation criterion. The uncertainty in the flow pattern evaluations, and especially the ability of the flow to suspend sludge at large distances from the pump nozzle, is directly related to the uncertainty in the suspension velocity found from the ECR analysis.

The results presented in Table 2 show that the critical flow velocity required to pick up a micron-sized solid particle in a clear fluid is negligibly small compared with the flow criterion determined from sludge suspension observations [2, 3]. The present flow criterion for the suspension and removal operations of the sludge in Tank 8 is supported by the values estimated from previous sludge removal operations [2]. Equation (2) 
shows that fluid velocity, particle size, specific gravity of particle, and tank liquid level are key parameters associated with particle suspension.

For the present analysis, local fluid velocity at any distance from the pump nozzle is compared to the flow criterion of $2.27 \mathrm{ft} / \mathrm{sec}$ as a measure or indicator for sludge removal in Tank 8.

The FLUENT ${ }^{\mathrm{TM}}$ [6] code, which was validated against velocity measurements in the fulltank facility located in TNX [3], was used to calculate waste flow patterns for the slurry mixers of Tank 8 to estimate the ability to suspend and remove sludge under potential operating conditions illustrated in Figs. 1 and 2. The slurry pump jet flow provides circulation within the 75-ft tank. The pump suction is located at the bottom of the jet pump as shown in Fig. 1. A three-dimensional CFD analysis was used to evaluate the impact of physical parameters such as tank level, pump elevation, and internal flow obstructions on the circulation patterns within the tank. The pump was assumed to be stationary, since rotational effects were found to be small from previous work [3]. The flow circulation patterns are directly related to the suspension and removal of the sludge mound located near the edge of the tank.

In previous work [3], the ability of the Fluent code to capture important flow phenomena associated with the mixing behavior of a submerged jet was demonstrated. A mesh sensitivity analysis for the computational domain was performed to determine whether the flow patterns calculated with a two-dimensional model were reasonable representations of jet flow evolution in the tank. The results showed that twodimensional models generally overestimate the magnitude of the flow velocity by more than $40 \%$ when compared to the TNX tests. This important result stems partly from neglecting the presence of the tank bottom, and partly from the two-dimensional model not having the capability to capture vertical flow rotation. With only one degree of freedom for rotational motion, the two-dimensional model cannot dissipate the jet as rapidly as a more realistic three-dimensional representation. Detailed discussions and results were provided in the previous document [3]. Therefore, the present analysis is based on a three-dimensional modeling approach.

The present analysis considers several basic cases with different boundary conditions to investigate how sensitive the velocity profiles are to different tank levels, pump positions, and internal flow obstructions for indexed pump operations. The models consist of two fundamental cases, Model-I and Model-II. One is the baseline studies without internal obstructions to evaluate the sensitivities of flow circulation patterns due to the change of the operational conditions of the tank. The other is the best estimate model with the internal obstructions created by the valve housing. This second model was used to estimate transient times to reach steady-state operational conditions from an initial quiescent tank, and to develop an operational strategy for removal of the sludge heel located in the east corner of Tank 8. In addition, the extent of the slurry mixing zone is estimated for a slurry mixer submerged at one of the four corners of the tank for given reference design conditions. Transient simulations are considered using Models Ic and Ila to estimate operational times for two different tank levels in terms of sludge flow evolution. Detailed modeling domain and operating conditions will be provided later. The model geometry was created using body-fitted coordinates and structured multiblock grids. Reference design conditions are shown in Table 4

Detailed wave motion of the free surface at the top of the tank was neglected for computational efficiency. That behavior does not have a significant impact on the flow 
Report: WSRC-TR-2002-00460

Date: $\quad 01 / 10 / 03$

Page:

14 of 58
WESTINGHOUSE SAVANNAH RIVER COMPANY

HEEL REMOVAL ANALYSIS FOR MIXING PUMPS OF TANK 8

patterns inside the slurry region in a deep tank. The fluid properties of water were evaluated at room temperature $\left(20^{\circ} \mathrm{C}\right)$. The flow conditions were assumed to be fully turbulent since Reynolds numbers for typical operating conditions were in the range of $10^{8}$ based on the pump nozzle inlet conditions. A standard two-equation turbulence model, the $\kappa-\varepsilon$ model [6], was used, since previous work [3, 7] showed that the twoequation model predicts the flow evolution of turbulent jet in a large stagnant fluid domain with reasonable accuracy. This model specifies the turbulent or "eddy" viscosity, $\mu_{t}$, by the empirical equation,

$$
\mu_{t}=\left(\frac{C_{\mu} \rho_{f} k^{2}}{\varepsilon}\right)
$$

Table 3. CFD modeling approaches taken for the present analysis.

\begin{tabular}{|c|c|c|c|}
\hline $\begin{array}{l}\text { Analysis } \\
\text { Models }\end{array}$ & $\begin{array}{l}\text { Analysis } \\
\text { Cases }\end{array}$ & $\begin{array}{l}\text { Modeling } \\
\text { Approaches }\end{array}$ & Primary Purposes \\
\hline \multirow{3}{*}{$\begin{array}{l}\text { Model-I } \\
\text { (Tank } 8 \\
\text { model } \\
\text { without } \\
\text { internal } \\
\text { obstructions) }\end{array}$} & Case-la & $\begin{array}{c}\text { 3-D steady- } \\
\text { state }\end{array}$ & $\begin{array}{l}\text { To perform sensitivity analysis of the flow } \\
\text { patterns due to the change of pump } \\
\text { elevation for the baseline operating } \\
\text { conditions with no flow obstructions }\end{array}$ \\
\hline & Case-lb & $\begin{array}{c}\text { 3-D steady- } \\
\text { state }\end{array}$ & $\begin{array}{l}\text { To evaluate the flow patterns for no internal } \\
\text { flow obstructions inside the tank and to } \\
\text { compare the sludge-heel removal capability } \\
\text { between the models with and without } \\
\text { obstructions for the baseline operating } \\
\text { conditions }\end{array}$ \\
\hline & Case-Ic & $\begin{array}{l}\text { 3-D steady- } \\
\text { state and } \\
\text { transient }\end{array}$ & $\begin{array}{l}\text { To evaluate sensitivity analysis of the } \\
\text { sludge-heel removal capability for liquid level } \\
\text { change for the baseline operating conditions } \\
\text { with no flow obstructions and to estimate } \\
\text { transient times to reach steady-state flow } \\
\text { patterns under low and high tank levels with } \\
\text { other conditions fixed }\end{array}$ \\
\hline \multirow{2}{*}{$\begin{array}{c}\text { Model-II } \\
\text { (Tank } 8 \\
\text { model with } \\
\text { internal } \\
\text { obstructions) }\end{array}$} & Case-Ila & $\begin{array}{c}\text { 3-D } \\
\text { transient }\end{array}$ & $\begin{array}{l}\text { To estimate the transient time to reach } \\
\text { steady state flow patterns for Tank } 8 \text { with } \\
\text { the slurry mixers located at the four corner } \\
\text { and } 130 \text { in liquid level in establishing ECR }\end{array}$ \\
\hline & Case-Ilb & $\begin{array}{c}\text { 3-D steady- } \\
\text { state }\end{array}$ & $\begin{array}{l}\text { To investigate the efficient performance of } \\
\text { sludge clearance and to develop an } \\
\text { operational strategy for Tank } 8 \text { sludge heel } \\
\text { removal using the four existing slurry mixers } \\
\text { located at the four corner of the tank under } \\
\text { the reference operating conditions }\end{array}$ \\
\hline
\end{tabular}


In eq. (9) $C_{\mu}$ is an empirical constant. In the present calculations, its value is 0.09 . The turbulent viscosity is computed by solving two transport equations for $k$ (turbulent kinetic energy) and $\varepsilon$ (rate of dissipation of turbulent energy). The governing equations to be solved for the present work are composed of one continuity equation, three momentum equations for the three component directions ( $x, y$, and $z$ directions), and two constitutive equations for the turbulence descriptions. Detailed descriptions for the governing equations and computational methods are provided in previous work [7].

\subsection{Tank 8 Model without Flow Obstructions (Model-I)}

Tank 8 is cylindrical, $75 \mathrm{ft}$ in diameter, and $24.5 \mathrm{ft}$ high. For the reference conditions, the tank liquid level was kept 130 in high. The model also considered a 40 -in liquid level to investigate the impact of tank level on the circulation pattern. The tank has four, 150 hp slurry pumps to suspend and remove the sludge mound. Each pump has two horizontal discharge nozzles, each 1.5 in in diameter. A total discharge flowrate of 1200 gpm corresponds to a pump speed of $1800 \mathrm{rpm}$. There is a single suction at the bottom of the pump. The mixer is located about $16.5 \mathrm{ft}$ away from the tank wall and about 26 in above the tank bottom as shown in Fig. 1. The model is a full three-dimensional representation of the entire tank to capture significant phenomena related to the turbulent behavior of the jet flow.

Water was used to simulate the fluid in the tank. Previous sensitivity results [3] showed that flow pattern impacts due to fluid property differences were negligibly small. Detailed geometrical and operating conditions are provided in Table 4. Based on nozzle diameter and water properties, flow near the nozzle is clearly turbulent; the Reynolds number is about $1.26 \times 10^{6}$. Although flow in remote regions far away from the nozzle is probably laminar, the flow for the entire computational domain is assumed to be turbulent to give a reasonable representation of the liquid jet leaving the pump nozzle. The code cannot handle both laminar and turbulent flow in a single calculation, although they exist in real flow situations.

For the turbulence calculations, the standard $\kappa-\varepsilon$ model was used. A three-dimensional model was run in transient and steady-state modes for the operating conditions of Tank 8 as shown in Table 4. Angular position of slurry pump with two discharge jets was fixed so that one of the two jets for each pump was pointed directly to the east corner of the Tank 8 aiming at the site of the sludge mound, while the other nozzle jet was pointed to the opposite wall. Geometrical configurations and layout for the model are illustrated in Fig. 6. For transient simulations, the pump was started in a quiescent tank. The transient calculations were performed for a fixed position of the jet nozzle until a quasisteady mixing flow pattern in the tank was reached.

Geometrical simplifications and physical model assumptions are listed as follows:

- There are no solid obstructions in the tank other than the pump riser and nozzle housing.

- Two discharge nozzles are $180^{\circ}$ apart, aligned in straight and opposite directions.

- The pump nozzle is stationary, although in reality, the pump has a slight oscillation.

- The working liquid is water at room temperature $\left(20^{\circ} \mathrm{C}\right)$.

- The liquid region is bounded by a free surface with constant atmospheric pressure. 
Report: WSRC-TR-2002-00460

Date: $\quad 01 / 10 / 03$

Page: $\quad 16$ of 58
WESTINGHOUSE SAVANNAH RIVER COMPANY

HEEL REMOVAL ANALYSIS FOR MIXING PUMPS OF TANK 8

- The model is isothermal. No energy equation is calculated.

- The flow in the entire model domain is assumed to be turbulent to give a reasonable representation of the liquid jet leaving the pump nozzle.

A typical hexahedral, non-uniform mesh for Model-I is shown in Fig. 6a. About a quarter million nodes for Model-I was established as an optimum for the three-dimensional computational domain shown in Fig. 6.

Table 4. Reference design and operating conditions of Tank 8 used for the present analysis.

\begin{tabular}{|c|c|c|}
\hline \multicolumn{2}{|c|}{ Parameters } & Conditions \\
\hline \multirow{2}{*}{ Tank dimensions } & Diameter & $75 \mathrm{ft}$ \\
\hline & Tank liquid level & 130 in* or 40 in high \\
\hline \multicolumn{2}{|c|}{ Mixing pump } & Lawrence slurry pump \\
\hline \multicolumn{2}{|c|}{ Number of pumps } & 1 to 4 pumps \\
\hline \multicolumn{2}{|c|}{ Pump nozzle diameter } & $1.5 \mathrm{in}$ \\
\hline \multirow{2}{*}{$\begin{array}{l}\text { Pump positions inside } \\
\text { the tank }\end{array}$} & $\begin{array}{l}\text { Vertical } \\
\text { elevations }\end{array}$ & $\begin{array}{c}26 \text { in }^{*} \text { or } 36 \text { in(from the center of pump } \\
\text { nozzle to tank bottom) }\end{array}$ \\
\hline & $\begin{array}{l}\text { Horizontal } \\
\text { locations }\end{array}$ & See Fig. 2 \\
\hline \multicolumn{2}{|c|}{ Tank fluid temperature } & $20^{\circ} \mathrm{C}$ \\
\hline \multicolumn{2}{|c|}{ Tank fluid } & Slurry $^{+}$(density: 1.2 SG, viscosity: $2 \mathrm{cp}$ ) \\
\hline \multirow{3}{*}{$\begin{array}{l}\text { Nozzle flowrate for } \\
\text { each nozzle } \\
\text { [fluid speed] }\end{array}$} & $1800 \mathrm{rpm}^{*}$ & $\begin{array}{l}600^{*} \mathrm{gpm} \\
{[109 \mathrm{ft} / \mathrm{sec}]}\end{array}$ \\
\hline & 1600 rpm & $\begin{array}{c}549 \mathrm{gpm} \\
{[99.6 \mathrm{ft} / \mathrm{sec}]}\end{array}$ \\
\hline & 2000 rpm & $\begin{array}{c}651 \mathrm{gpm} \\
{[118 \mathrm{ft} / \mathrm{sec}]}\end{array}$ \\
\hline
\end{tabular}

Note:* Baseline reference operating conditions

+ Water $\left(20^{\circ} \mathrm{C}\right)$ was used as a simulant for the present analysis, but slurry was used in the sensitivity analysis. 


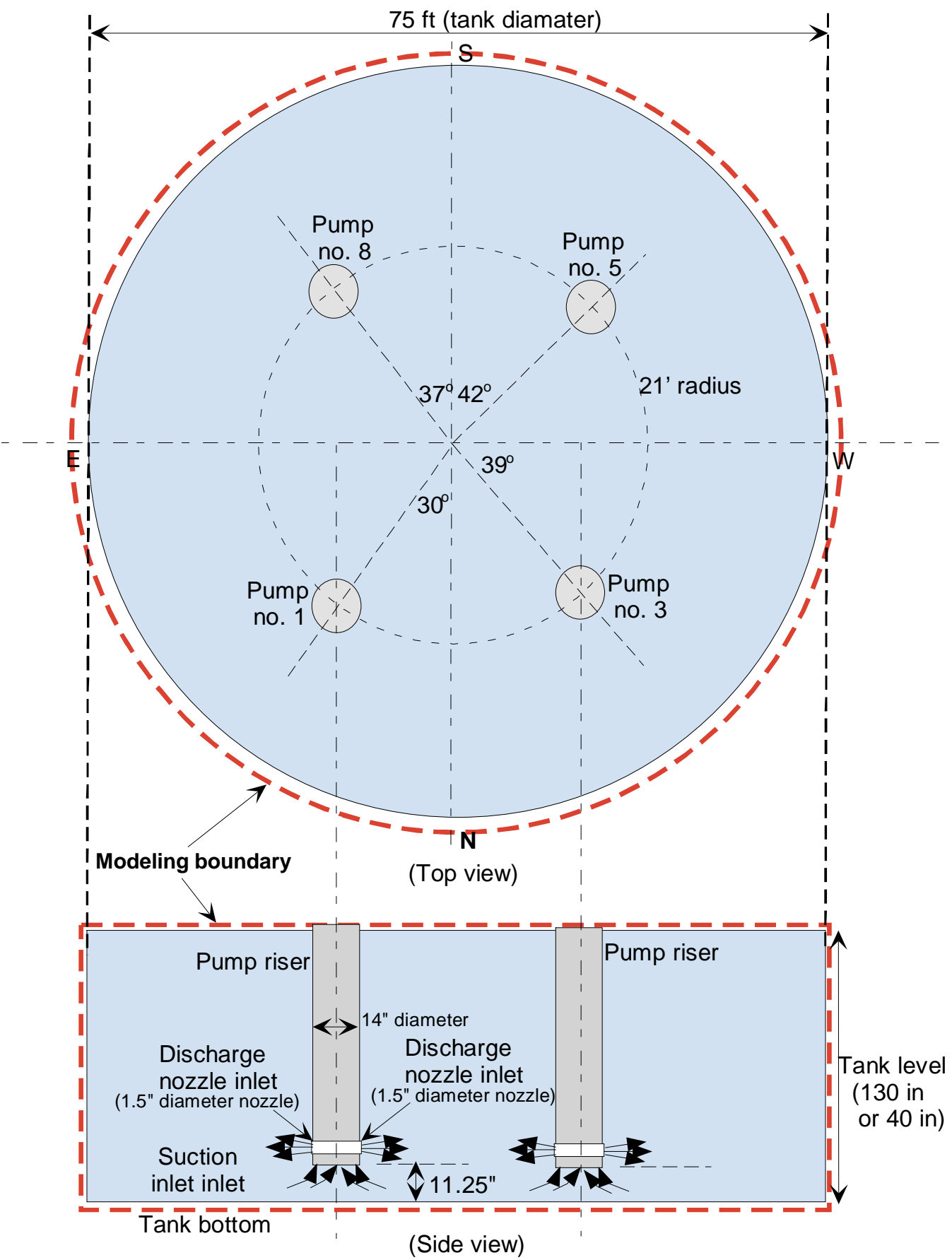

Figure 6. Three-dimensional modeling boundary for Model-I in the present analysis of the Tank 8 facility with four slurry pumps 
Report: WSRC-TR-2002-00460

Date: $\quad 01 / 10 / 03$

Page: $\quad 18$ of 58
WESTINGHOUSE SAVANNAH RIVER COMPANY

HEEL REMOVAL ANALYSIS FOR MIXING PUMPS OF TANK 8

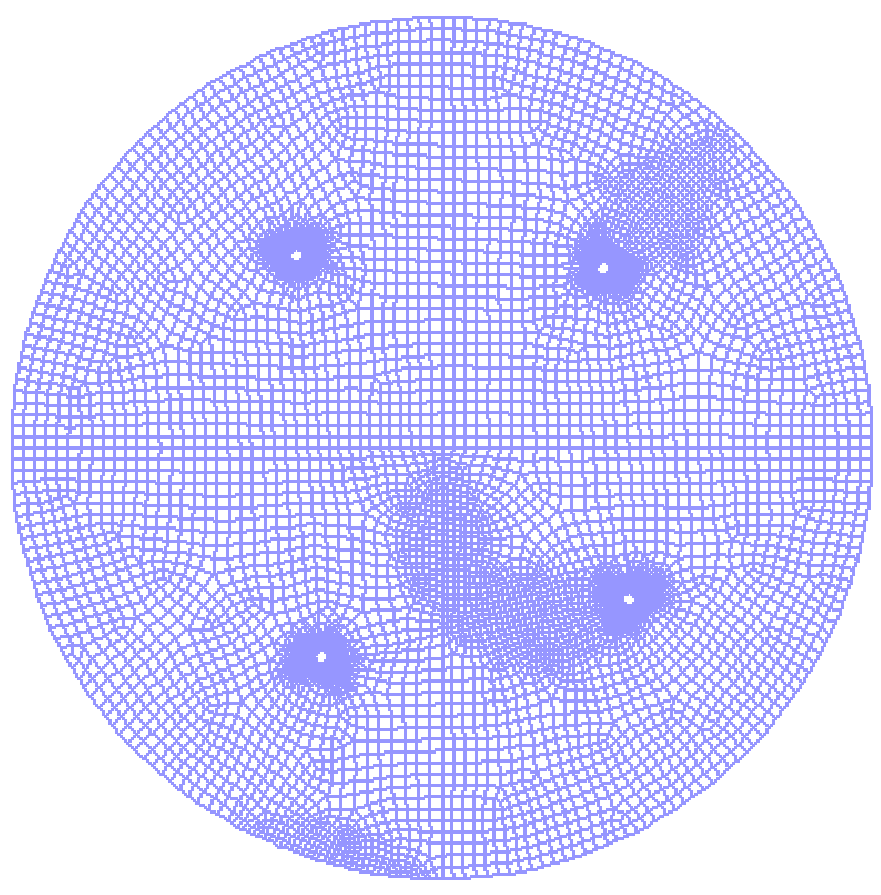

$L_{x}$

Figure 6a. Hexahedral meshes on the x-y computational domain of Model-I for a threedimensional CFD model of Tank 8 with four mixing pumps. 


\subsection{Tank 8 Model with Flow Obstructions (Model-II)}

Model II used assumptions similar to Model I except for the internal flow obstructions representing the valve housing to control cooling coil flow. The valve housing consists of two banks of 2-in diameter tubes as shown in Fig. 7. Detailed dimensions and pump layouts are shown in the figure.

The calculations consisted of several different cases to simulate various operating conditions for Tank 8 and to examine the sensitivities of the operating parameters with respect to the efficiency of sludge suspension and waste removal. Detailed descriptions for all the cases are provided in Table 5. The three-dimensional model was run in a transient mode for the fixed pumps to allow the jet flow to develop and ultimately approach a steady state pattern. For the two-pump model, the pumps are in a fixed orientation to maximize flow streams aimed at the sludge heel located near the east corner of the tank. Both discharge jets are located at a horizontal plane 26 in above the tank bottom. "For the multi-pump model, the pump speed was $1800 \mathrm{rpm}$ for the reference conditions and $1600 \mathrm{rpm}$ and $2000 \mathrm{rpm}$ for the sensitivity study. Detailed geometrical configurations for the multi-pump model are shown in Fig. 8. For the transient simulations, the initial conditions of the fluid medium were assumed to be quiescent. The transient runs progressed in a fixed pump orientation until a quasisteady flow pattern was reached.

The main assumptions used in the Tank 8 models are listed as follows:

- There are no solid obstructions in the tank other than the pump support structure, nozzle housing, and valve housing as shown in Fig. 7 or Fig. 8.

- Two discharge nozzles are $180^{\circ}$ apart, aligned in straight and opposite directions.

- The pump nozzle is stationary.

- The working liquid is water at room temperature $\left(20^{\circ} \mathrm{C}\right)$.

- The liquid region is bounded by a free surface at constant atmospheric pressure.

- The model is isothermal. No energy equation is calculated.

- The flow in the entire domain is assumed to be turbulent.

- The wavy motion of the free surface due to the interaction with the discharge jet is neglected. Literature data [Ref. 7] show that the surface wave effect is negligible when the ratio of liquid height above the nozzle to nozzle diameter is larger than 2.5 . For a slurry mixer in Tank 8 , the minimum ratio is about 9.3 for the 40 in liquid level case.

Three-dimensional numerical simulations were made for the Model-II analysis. About 350,000 hexahedral elements were established as an optimum number of computational nodes for numerical convergence and computational time.

\footnotetext{
* The actual nozzle discharge elevation for each slurry pump in Tank 8 is slightly different. The impact of this difference is expected to be small.
} 
Report: WSRC-TR-2002-00460

Date: $\quad 01 / 10 / 03$

Page: $\quad 20$ of 58
WESTINGHOUSE SAVANNAH RIVER COMPANY

HEEL REMOVAL ANALYSIS FOR MIXING PUMPS OF TANK 8

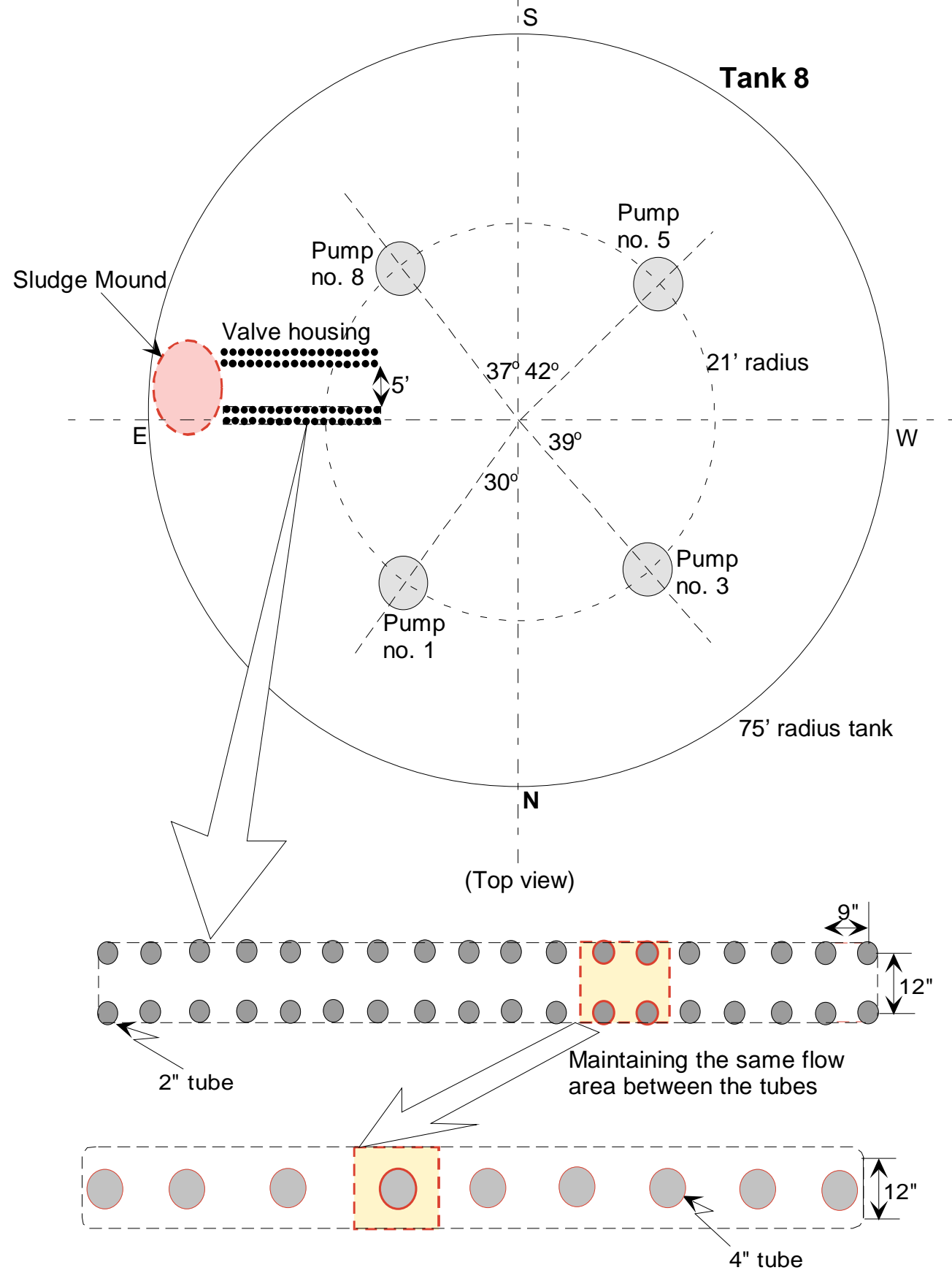

Figure 7. Schematic illustrations for the Model-II modeling boundary of Tank 8 with four slurry pumps including flow obstructions representing valve housing for cooling-coil flow control. 


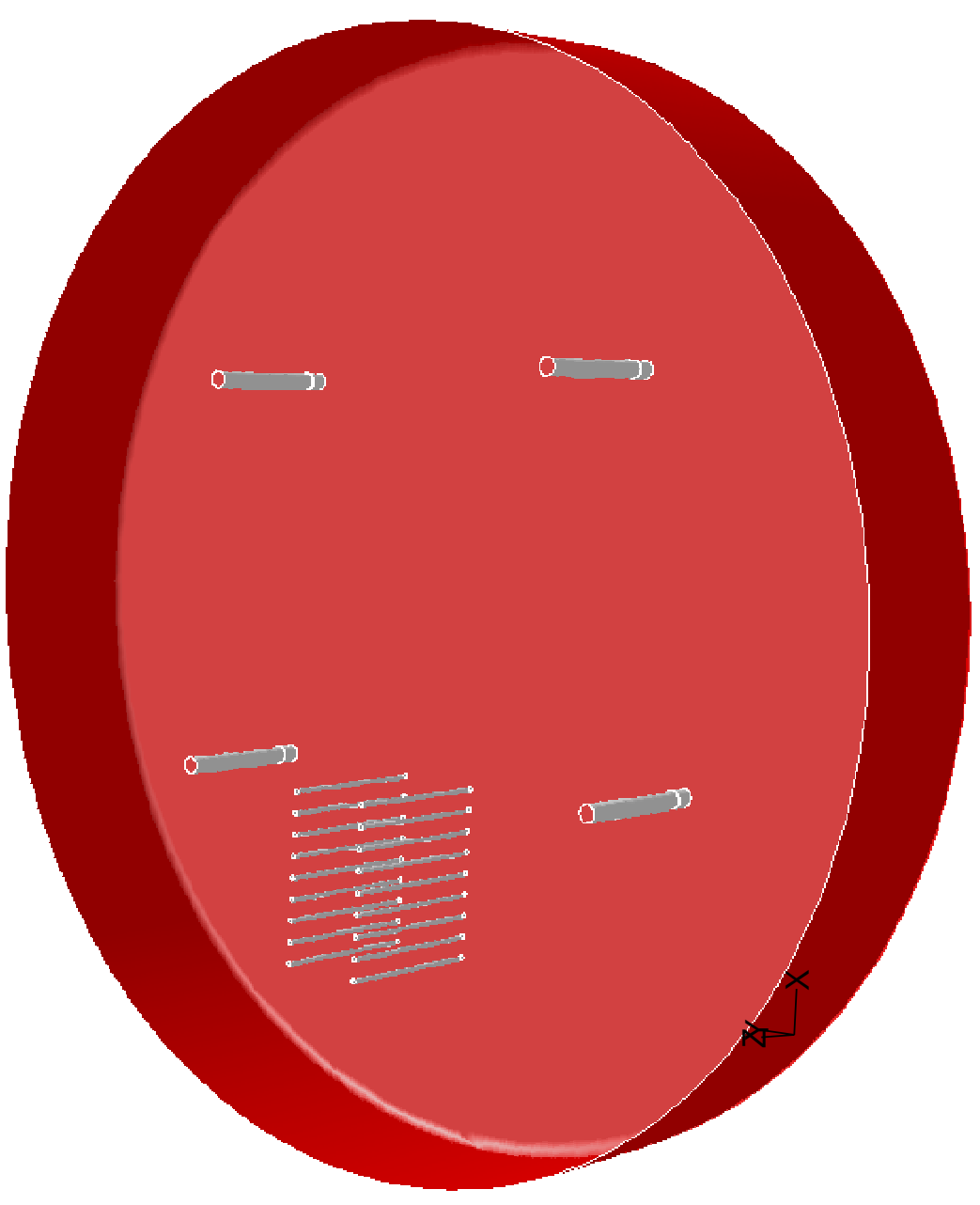

Figure 8. Three-dimensional CFD model of Tank 8 with four mixing pumps considering obstruction effects of valve housing consisting of 18 cooling pipes. 
Page: $\quad 22$ of 58

\section{Results and Discussions}

CFD models were developed and analyses performed to estimate circulation flow patterns within Tank 8 to evaluate the ability of the four slurry pumps to remove the sludge mound remaining in the tank. The mixing pumps are assumed to be stationary, since previous results [3] showed that rotational effects on flow patterns are negligible. A flow velocity criterion will be used as the primary indicator of the ability to suspend sludge.

Two basic models were developed, including three cases for the model without internal flow obstructions (Model-I) and two cases for the model with obstructions(Model-II). The primary objective for Model-I is to perform sensitivity analyses for operational parameters such as pump elevation, internal flow obstructions, and liquid levels. ModelII is mainly to evaluate flow circulation patterns to develop an operational strategy for Tank 8 sludge removal operations. Descriptions of each case are provided in Table 3.

The sludge mound is located near the east corner of the tank, where the valve housing to control cooling coil flow stands. Because of the distance from the nearest slurry pump to the sludge mound, as well as the apparent obstruction to the slurry jet flow formed by the valve housing, major questions are the optimum number of operating pumps and the most effective discharge direction of each to remove the sludge heel. The location and dimensions of the sludge mound are shown in Fig. 3.

Figure 9 shows the calculation results for velocity magnitude along the centerline through the sludge heel area using Model-I when various numbers of operating pumps are aimed at the sludge mound. The results show that velocity magnitude near the wall region for a two-pump operation (pump no. 5 and no. 8) is increased by about $10 \%$ compared to a single pump operation (pump no. 8) for the same elevation. It is noted that the most effective sludge removal flow occurs when two pumps are operating, all other operating parameters fixed. Thus, it is not necessary or advantageous to operate all four pumps simultaneously for efficient removal of the sludge mound. The detailed operating strategy for sludge removal will be developed in terms of numbers of operating pumps and discharge using the performance model (Model-II) later.

As discussed earlier, a flow velocity criterion was used as the primary indicator to assess the sludge removal capability for various different operating conditions. Flow patterns were evaluated for two different pump elevations with all other parameters fixed (Case-la). The reference pump elevation was 26 in as shown in Table 4 . A higher pump elevation of 36 in was used, since the nozzle cannot be lowered below 26 in and can only be raised in 10-in increments [1]. The results are compared in Figs. 9a, 10, and 11. Flow patterns at the corner regions adjacent to the wall boundary are more active than in the central region of the tank because of fluid vortices generated due to the presence of the tank wall boundary. It is noted that the higher pump elevation is generally less efficient than the lower in terms of sludge removal capability, but it is only slightly different in terms of flow circulation.

As shown in Table 3, two different models were developed to investigate the impact of flow performance due to the presence of flow obstructions inside the tank (Case-lb). The results show that internal obstructions of the tank sometimes help guide the flow to a certain direction as shown in Fig. 12. Figure 13 shows that when two pumps are under operation, maximum flow velocity calculated by the model with obstructions 
increases by about $15 \%$ compared with the one without obstructions. When four pumps are in operation and all the pumps aim at the direction similar to the case with two pumps, the results for the model with flow obstructions are lower than the other model as shown in Figs. 14 and 15. This result stems from the interference effect of pump nozzle flows with different discharge directions as graphically shown Fig. 14 . It is pointed out that simultaneous operation of all pumps is not needed for an efficient suspension and removal of the sludge mound located at a local position.

Sludge removal capability was evaluated for two different liquid levels with all other parameters fixed. The reference liquid level was 130 in as shown in Table 4. The two pumps used for the simulation run were stationary with nozzles at the same elevation. The lower tank level was 40 in for Case-lc. The results are compared in Figs. 16 and 17. The results show that the discharge flow for the lower tank level dissipates along the principal discharge direction more quickly than the one with the higher level within about $30 \mathrm{ft}$ from the tank center, but the velocity for the model with the higher tank level becomes larger as the distance increases from $30 \mathrm{ft}$ to $37 \mathrm{ft}$ (near the wall boundary). This is mainly due to the larger momentum dissipation from the free surface in the case of a lower tank level as graphically compared in Fig. 16. It is noted that the high tank level is more efficient than the other in terms of sludge removal capability. This result is consistent with the previous Tank 18 results [3].

Model-I transient simulations with two pumps running were made to estimate transient times to reach steady-state flow patterns. The calculated results showed that jet flows from the two nozzles of the mixer were dissipated quickly along the principal discharge directions within about 15 seconds. As soon as the flow exits the nozzle, four main circulation cells are generated around the tank, one on each side of the centerline for each nozzle. Within about 100 seconds after the pump start, the nozzle facing the center of the tank created two dominant cells, but after about 220 seconds, all three cells were developed to about the same circular size. This circulating flow pattern will help to understand the suspension and removal of waste sludge. The transient velocity profiles along the centerline A'-A for several transient times are shown in Fig. 17a. It takes about 4 minutes for the tank with 130 in liquid level to reach steady-state flow circulation from the initial quiescent condition and about 3 minutes for the 40 in tank level under the reference pump speed (1800 rpm). For the slower pump speed (1600 rpm), transient times with 130 in tank level are about 260 seconds. Transient times to reach steady-state flow patterns are similar for two and three operating pumps with the same speed. The calculation results are compared in Table 5.

Transient behavior of the flow evolution was examined by the performance model (Model-II) to evaluate the development of the clearing distance from a fixed pump. Snapshots of transient flow patterns in Tank 8 are presented in Fig. 18. The results show that steady flow patterns are reached in about 220 seconds. The results of the two transient models, Model-I and Model-II, are about the same at the reference tank level (130 in).

As mentioned earlier, the primary goal of the Tank 8 model is to determine what operational conditions result in the maximum clearing capability of the sludge using the existing waste removal equipment. Therefore, it is important to quantify the maximum clearing distance of each mixer. 
Report: WSRC-TR-2002-00460

Date: $\quad 01 / 10 / 03$

Page: $\quad 24$ of 58
WESTINGHOUSE SAVANNAH RIVER COMPANY

HEEL REMOVAL ANALYSIS FOR MIXING PUMPS OF TANK 8

Model-II was used to estimate the distance at which the sludge removal velocity was maintained under three pump operations. The three pumps are no. 1, no. 3, and no. 5, and they are stationary. The present calculations used $2.27 \mathrm{ft} / \mathrm{sec}$ as the minimum velocity for the sludge removal, which was estimated earlier using previous works [2, 3]. The results showed that the maximum distance for the sludge removal was about $25.5 \mathrm{ft}$ from the nozzle of pump no. 3 along the principal discharge direction $A^{\prime}-A$ under the multi-pump conditions.

Table 5. Comparison of operational times to reach steady-state mixing flow patterns for three different situations

\begin{tabular}{|c|c|c|c|}
\hline $\begin{array}{c}\text { No. of operating pumps } \\
\text { (Pump no. in Tank 8) }\end{array}$ & $\begin{array}{c}\text { Tank liquid } \\
\text { level }\end{array}$ & $\begin{array}{c}\text { Pump } \\
\text { speed }\end{array}$ & $\begin{array}{c}\text { Operational times* to reach } \\
\text { steady-state flow pattern }\end{array}$ \\
\hline $\begin{array}{c}2 \text { pumps } \\
\text { (Pump no. 5 and no. 8 as } \\
\text { identified in Fig. 1) }\end{array}$ & $130 \mathrm{in}$ & $1800 \mathrm{rpm}$ & $\sim 180 \mathrm{sec}$. \\
\cline { 2 - 4 } & & $1800 \mathrm{rpm}$ & $\sim 220 \mathrm{sec}$. \\
\cline { 3 - 4 } & & $1600 \mathrm{rpm}$ & $\sim 260 \mathrm{sec}$. \\
\hline $\begin{array}{c}\text { (Pump no. 1, no. 5, and no. } \\
8 \text { as identified in Fig. 1) }\end{array}$ & $130 \mathrm{in}$ & $1800 \mathrm{rpm}$ & $\sim 220 \mathrm{sec}$. \\
\hline
\end{tabular}

Note: * Pump starts in a quiescent tank as initial condition.

This result is in reasonable agreement with the measurement data [2]. As shown in the velocity contour plot in Fig. 19, flow velocity at $27 \mathrm{ft}$ away from the nozzle exit of pump no. 3 start to increase due to the combined effect of the pump no. 1 discharge, which is stationed at the downstream side of the pump.

The present analysis used $1800 \mathrm{rpm}$ pump speed as one of the reference conditions. When pump speed is reduced from $1800 \mathrm{rpm}$ to $1600 \mathrm{rpm}$, the impact of the speed change on the performance of sludge removal operations was evaluated by Model-II in terms of flow patterns using the simultaneous operations of two pumps with other parameters fixed. The two operating pumps are pump no. 5 and 8 , and their elevations are 26 in high from the tank bottom. As expected, the tank flow patterns were not changed as shown in Fig. 20, but local speed near the potential locations of sludge mound was reduced with the reduction of pump speed. The results showed that maximum speed near the tank boundary region of the valve housing area was reduced about $9 \%$ when the pump speed is reduced from $1800 \mathrm{rpm}$ to $1600 \mathrm{rpm}$. The detailed comparisons between the two speeds are shown in Fig. 21.

Model-II, as shown in Table 3, was mainly used for the evaluation analysis of the tank sludge operation since the model included vertical obstructions representing valve housing structures to control cooling coil flow. Reference operating conditions are 
shown in Table 4. The model results were used to provide recommended operational scenarios for number of pumps, nozzle orientation, and pump speeds to suspend and transfer the remaining sludge. A detailed mapping of the four slurry pump locations, valve housing structure, and the sludge heel dimensions are shown in Fig. 2.

From the graphical results shown in Fig. 22, a single pump operation with pump no. 8, designated as Case-A, was taken as the first configuration. The most efficient direction of the pump 8 nozzle was found to be $38^{\circ}$ toward the sludge mound. Internal obstructions helped guide the flow into the zone of the sludge mound; the flow velocity increased about $10 \%$ compared to the model without flow obstructions. The maximum velocity at the estimated location of the sludge mound was about $2.1 \mathrm{ft} / \mathrm{sec}$ corresponding to about $92 \%$ of the sludge removal velocity $(2.27 \mathrm{ft} / \mathrm{sec})$. The results for the velocity distributions on the exit plane of the pump nozzle are shown in Fig. 22.

As a second case (Case-B), two pumps were used to increase the flow enough to mobilize and transport the sludge, since the Case-A results showed that one pump could not attain the sludge removal velocity. In this case, pump no. 5 was added to the pump no. 8 operation so that two pumps could operate simultaneously. The best combinations of the two nozzle directions were $16^{\circ}$ for pump no. 5 and $38^{\circ}$ for pump no. 8. The results showed that local velocity at the location of the sludge mound region was $2.30 \mathrm{ft} / \mathrm{sec}$, slightly exceeding the minimum the sludge removal velocity. Flow patterns for Case-B are shown in Fig. 23.

For Case-C, two pumps were selected to mobilize the north side portion of the sludge mound just behind the valve housing structures (about 6ft away from the tank wall boundary). For this case pump no. 1 and pump no. 3 were operated at the same time. Local flow velocities between about $4.5 \mathrm{ft}$ and $11 \mathrm{ft}$ away from the tank wall near the sludge mound were found to be higher than the minimum speed of the sludge removal. The graphical results for the Case-C flow patterns are shown in Fig. 24.

For Case-D, the simultaneous operation of three pumps was taken to remove the front side of the sludge mound as well as peripheral sides of the sludge mound around the valve housing. The results showed that most of the sludge mound located near the valve housing area could be mobilized. Figure 25 shows the results for the velocity contour plot.

Lastly, as Case-E, numerical simulations for the simultaneous operation of all pumps available in Tank 8 were made to stir up the entire sludge area around valve housing. Two-dimensional flow distributions on the discharge plane of the four pump nozzles are shown in Fig. 26. Flow patterns at the same plane are presented in Fig. 26a. Although all the cases evaluated here were for a fixed sludge mound, Case- $E$ can be combined with the previous four cases to form a suggested pump operating cycle for mobilizing and removing the sludge. Detailed results for all five cases are summarized in Table 6. Flow velocity results of the five cases under the reference conditions (1800 rpm pump speed) along the centerline crossing the potential sludge mound are shown in Fig. 27. As another scenario of the sludge removal operation, the simulations with lower pump speed (1600 rpm) and higher pump speed (2000 rpm) were made using the same operating conditions as the $1800 \mathrm{rpm}$ case. The results for the reduced speed case showed that sludge mound near the tank wall boundary could not be removed in terms of the minimum velocity criterion required for the sludge removal. The detailed results for the two different pump speeds are shown in Figs. 28 and 29. 
Report: WSRC-TR-2002-00460

Date: $\quad 01 / 10 / 03$

Page: $\quad 26$ of 58
WESTINGHOUSE SAVANNAH RIVER COMPANY

HEEL REMOVAL ANALYSIS FOR MIXING PUMPS OF TANK 8

Table 6. Pump nozzle locations for efficient operation of sludge heel removal under the reference operating conditions shown in Table 4

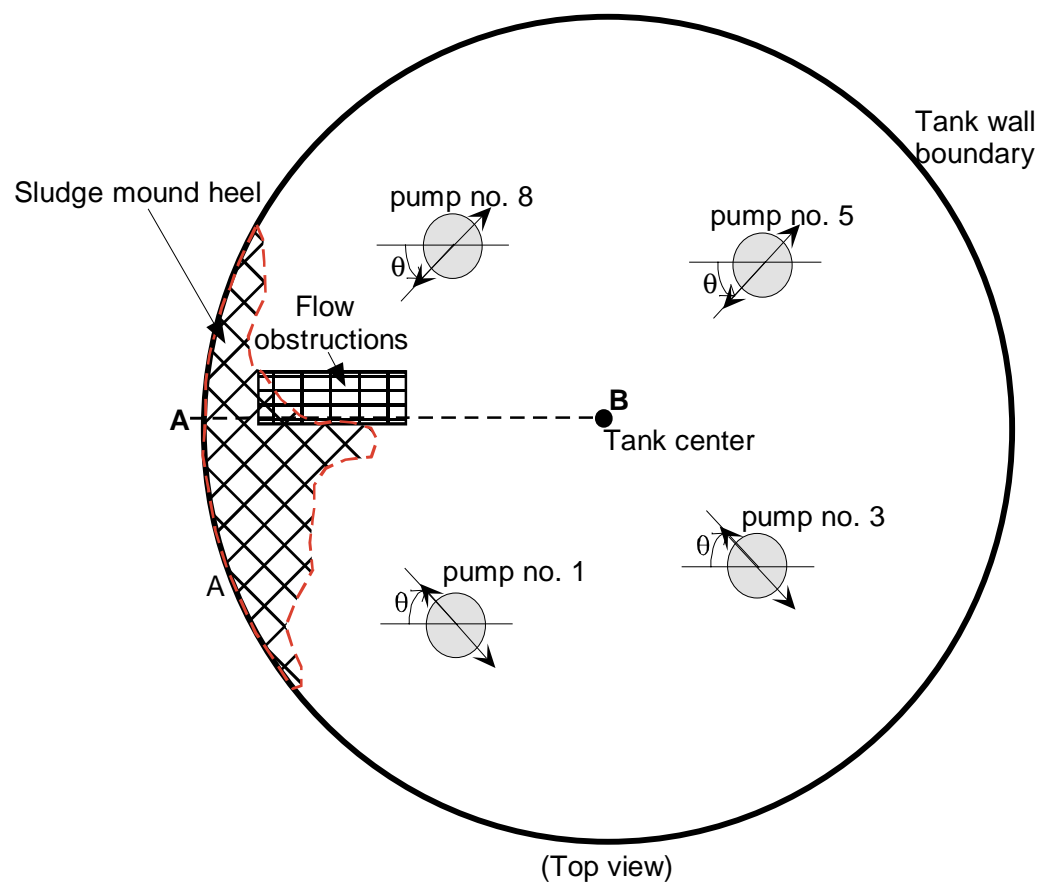

\begin{tabular}{|c|c|c|c|c|c|}
\hline \multirow{2}{*}{ Cases } & $\begin{array}{c}\text { Number of } \\
\text { operating pumps }\end{array}$ & \multicolumn{4}{|c|}{$\begin{array}{c}\text { Pump identifications } \\
\text { (as shown above) }\end{array}$} \\
\cline { 2 - 6 } & $\begin{array}{c}\text { (angle } \theta \text { as shown } \\
\text { above) }\end{array}$ & no. 1 & no. 3 & no. 5 & no. 8 \\
\hline \multirow{2}{*}{ Case-A } & 1 & off & off & off & operation \\
\cline { 2 - 6 } & (aiming angle, $\theta^{*}$ ) & -- & -- & -- & $38^{\circ}$ \\
\hline \multirow{2}{*}{ Case-B } & 2 & operation & operation & off & off \\
\cline { 2 - 6 } Case-C & (aiming angle, $\theta^{*}$ ) & $43^{\circ}$ & $22^{\circ}$ & -- & -- \\
\cline { 2 - 6 } & (aiming angle, $\theta^{*}$ ) & -- & -- & $16^{\circ}$ & $27^{\circ}$ \\
\hline \multirow{2}{*}{ Case-D } & 3 & off & off & operation & operation \\
\cline { 2 - 6 } & (aiming angle, $\theta^{*}$ ) & $54^{\circ}$ & -- & $16^{\circ}$ & $27^{\circ}$ \\
\hline \multirow{2}{*}{ Case-E } & 4 & operation & operation & operation & operation \\
\cline { 2 - 6 } & (aiming angle, $\theta^{*}$ ) & $65^{\circ}$ & $22^{\circ}$ & $27^{\circ}$ & $27^{\circ}$ \\
\hline
\end{tabular}


Note: * Angle $\theta$ represents the angle made by the discharge flow direction of each pump nozzle and the horizontal line A-B aiming at the east corner of Tank 8 (sludge mound corner) as shown in the figure.

It is important to recognize that local velocity is not the only parameter affecting the ability of the liquid stream to suspend and transport sludge. The length of time that the sludge is exposed to the liquid stream is also important, and this effect is not captured in the present analysis. A longer exposure time, as would be the case for an indexed pump rather than a continuously rotating pump, could reasonably be expected to result in greater erosion of the sludge layer at a given position.

The present analyses have been performed using water as the working fluid. Different fluid properties, which are similar to typical slurry fluids in Tank 8 as shown in Table 4, were used to examine the sensitivity of the flow patterns to these changes. The results show that the flow patterns are not sensitive to changes of fluid properties. At the discharge plane, there are no apparent differences in flow evolution. At the 26 in elevation, slurry flow around the horizontal discharge direction of the nozzle dies out slightly more quickly than water since radial diffusion is increased relative to convection when the fluid viscosity is increased from water $(1 \mathrm{cp})$ to slurry $(2 \mathrm{cp})$. It is noted that the radial flow behavior induced by the slurry is larger than that for water because of the increased diffusion in the momentum transport. However, when the maximum clearing distance (MCD) is defined as the distance over which the jet velocity exceeds the minimum suspension velocity, differences in the MCD for water and slurry are negligible. This result is consistent with the previous results of the Tank 18 analyses [3]. These results are summarized in Table 7.

Table 7. Sensitivity results for different fluid properties in the Tank 8 model in terms of maximum clearing distance (MCD)

\begin{tabular}{|c|c|c|c|c|}
\hline Cases & $\begin{array}{c}\text { Pump } \\
\text { position } \\
\text { (Liquid level) }\end{array}$ & Tank fluid & $\begin{array}{c}\text { Nozzle } \\
\text { velocity } \\
\text { (ft/sec) }\end{array}$ & $\begin{array}{l}\text { Max. Clearing } \\
\text { Distance* } \\
(2.27 \mathrm{ft} / \mathrm{sec} \text { or } \\
0.69 \mathrm{~m} / \mathrm{sec})\end{array}$ \\
\hline \multirow{2}{*}{$\begin{array}{c}\text { Tank } 8 \text { Model } \\
\text { (Model-II) }^{\star \star}\end{array}$} & \multirow{2}{*}{$\begin{array}{c}\text { Fixed } \\
(130 \mathrm{in})\end{array}$} & Water & 108.9 & $25.5 \mathrm{ft}$ \\
\hline & & $\begin{array}{c}\text { Slurry } \\
\text { (1.2sg and 2cp) }\end{array}$ & 108.9 & $25.4 \mathrm{ft}$ \\
\hline
\end{tabular}

Note: * MCD was defined as the distance from the nozzle exit of the pump to the point at which local velocity reaches minimum suspension (or specified) velocity.

** Operating conditions for Case-I was defined in Table 4. 

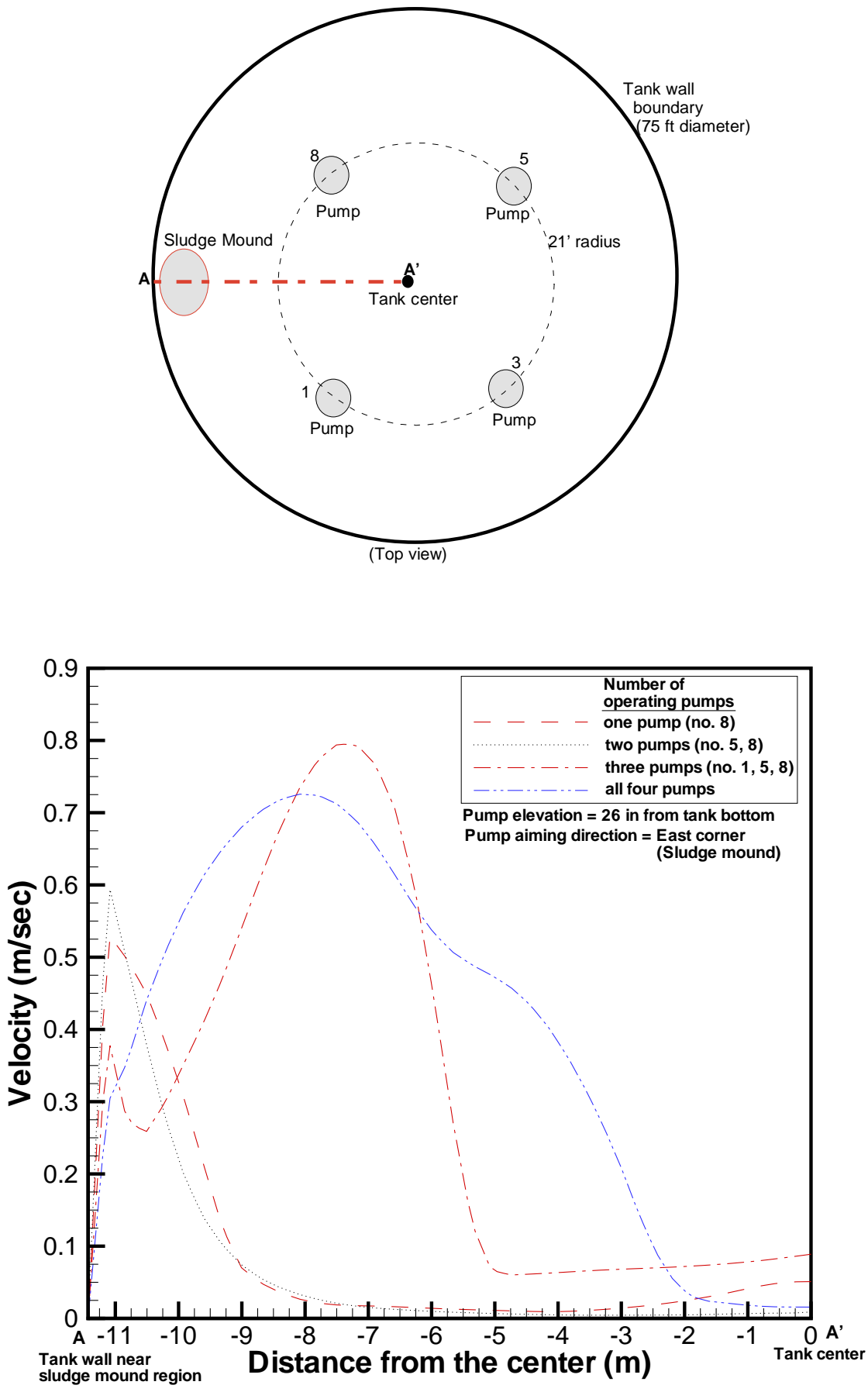

$(1 \mathrm{~m} / \mathrm{sec}=3.28 \mathrm{ft} / \mathrm{sec})$

Figure 9. Flow velocity magnitudes along the centerline A'-A of Tank 8 at the dischage elevation of slurry pump for various numbers of operating pumps using the tank model with no internal flow obstructions (Model-I). 

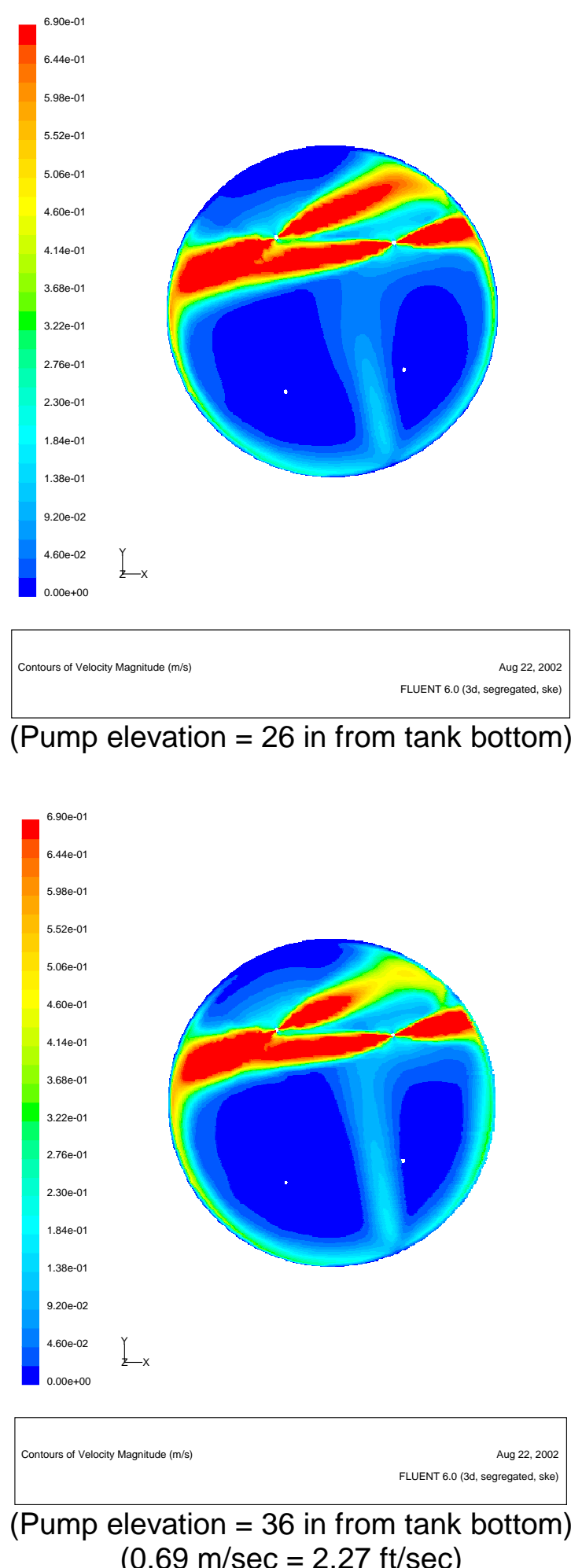

Figure 9a. Comparison of flow patterns at the nozzle exit plane between 26 in and 36 in pump elevations under the operating conditions of two slurry pumps. 
Report: WSRC-TR-2002-00460

Date: $\quad 01 / 10 / 03$

Page: $\quad 30$ of 58
WESTINGHOUSE SAVANNAH RIVER COMPANY

HEEL REMOVAL ANALYSIS FOR MIXING PUMPS OF TANK 8
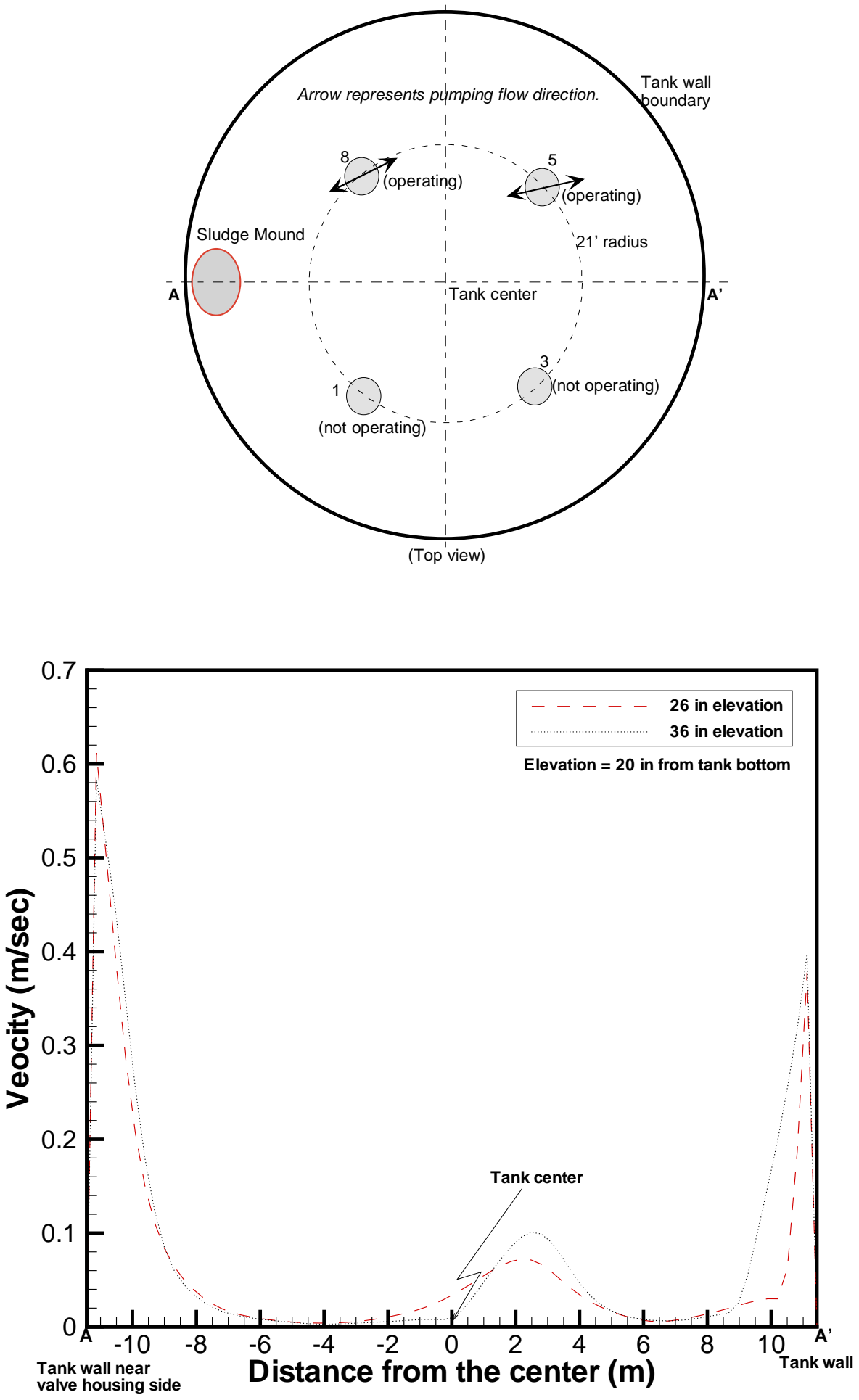

$(1 \mathrm{~m} / \mathrm{sec}=3.28 \mathrm{ft} / \mathrm{sec})$

Figure 10. Comparison of flow velocities at 20in elevation from the tank bottom between 26 in and 36 in pump elevations under the operating conditions of two slurry pumps. 

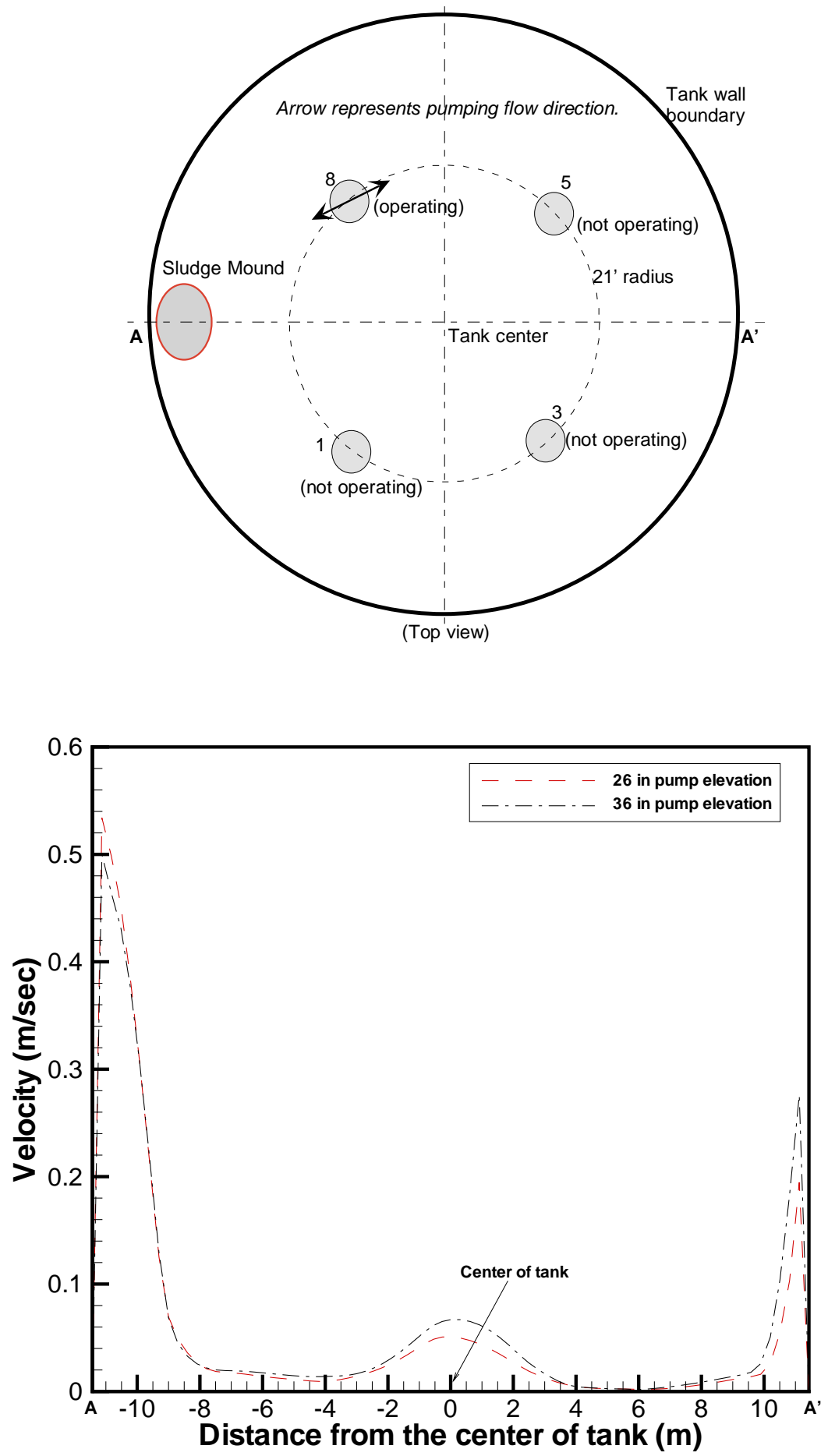

$(1 \mathrm{~m} / \mathrm{sec}=3.28 \mathrm{ft} / \mathrm{sec})$

Figure 11. Comparison of flow velocities at the nozzle exit plane between 26 in and 36 in pump elevations under the operating conditions of one slurry pump. 
Date: $\quad 01 / 10 / 03$

Page: $\quad 32$ of 58
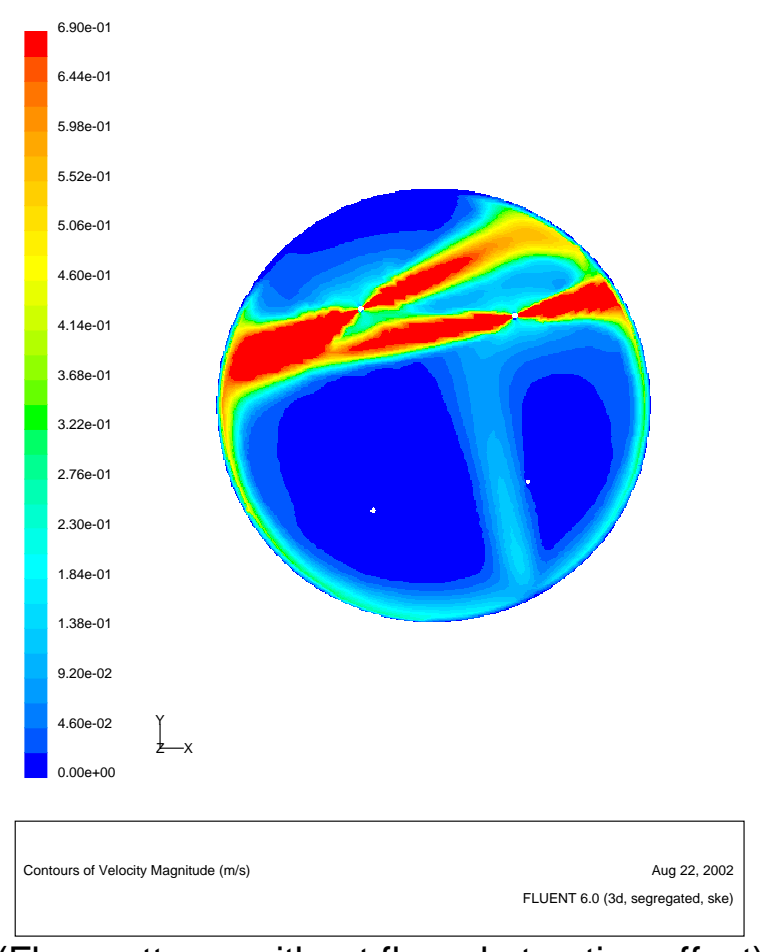

(Flow patterns without flow obstruction effect)
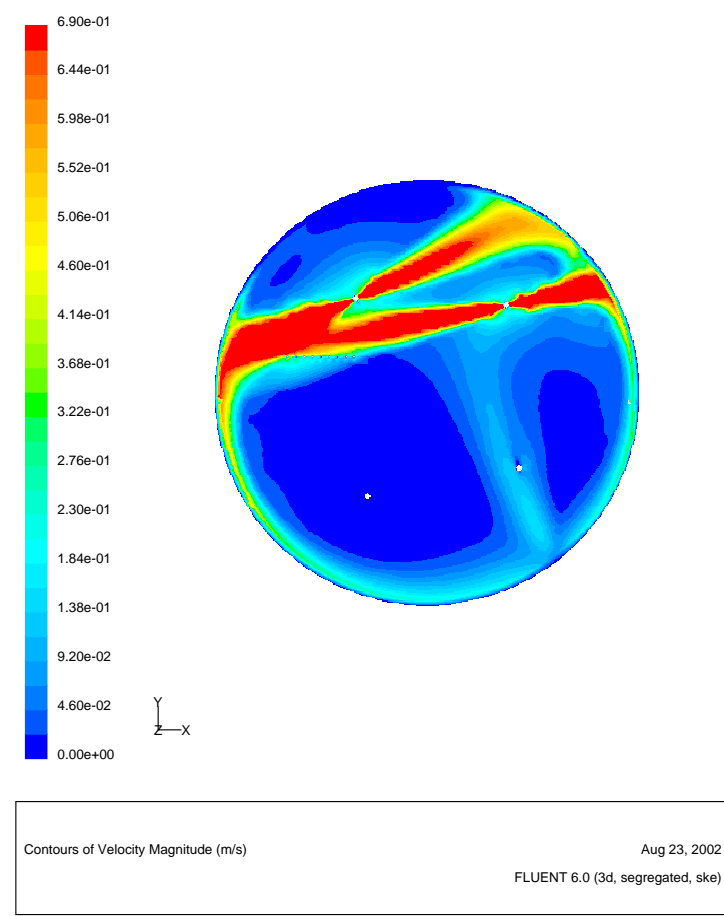

(Flow patterns with flow obstruction effect including valve housing) $(0.69 \mathrm{~m} / \mathrm{sec}=2.27 \mathrm{ft} / \mathrm{sec})$

Figure 12. Comparison of flow patterns at the nozzle inlet plane between the models with and without flow obstructions under the operating conditions of two slurry pumps. 

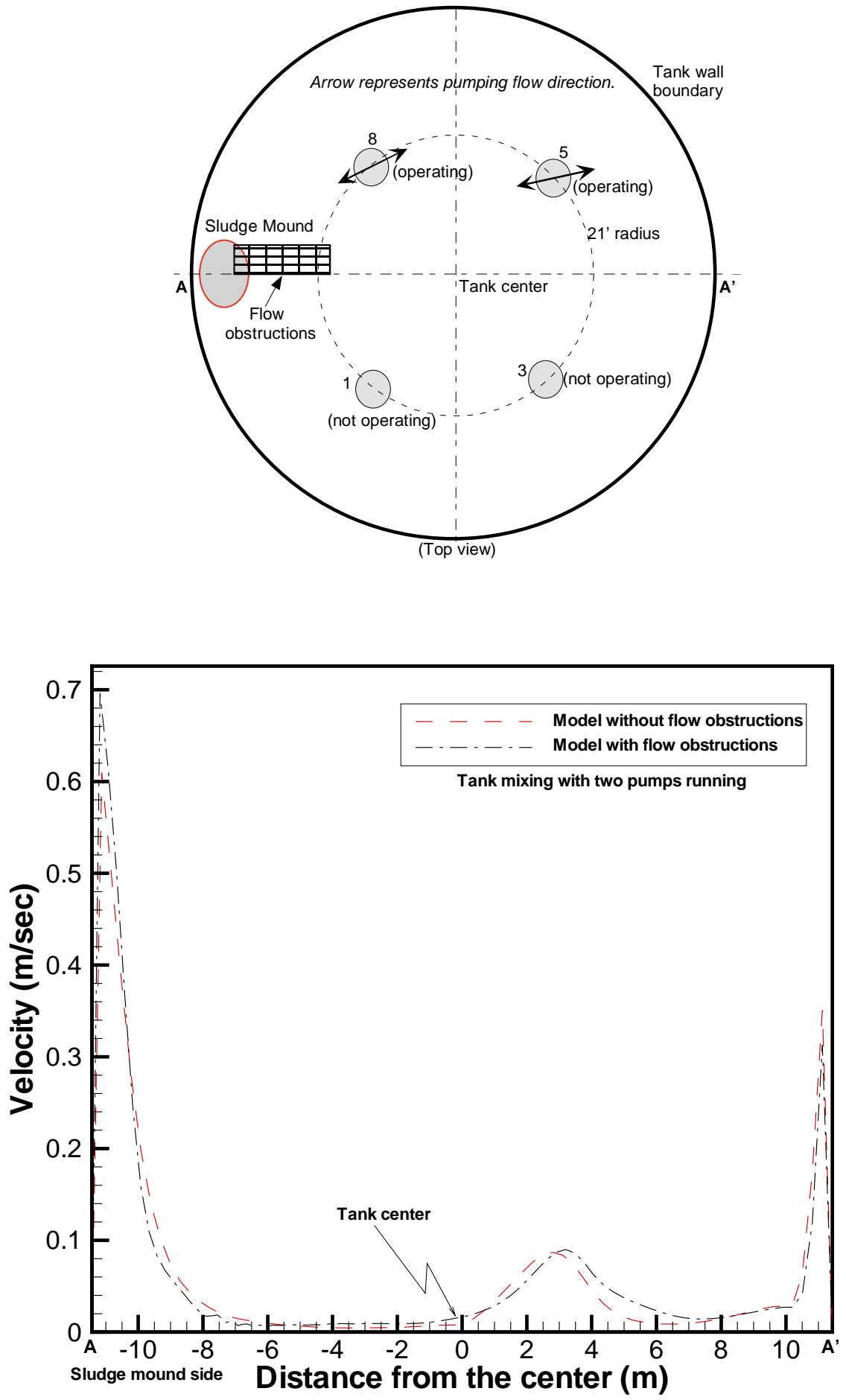

$(1 \mathrm{~m} / \mathrm{sec}=3.28 \mathrm{ft} / \mathrm{sec})$

Figure 13. Comparison of flow velocities along the line A-A' between the models with and without flow obstructions under the operating conditions of two slurry pumps. 
Report: WSRC-TR-2002-00460

Date: $\quad 01 / 10 / 03$

Page: $\quad 34$ of 58

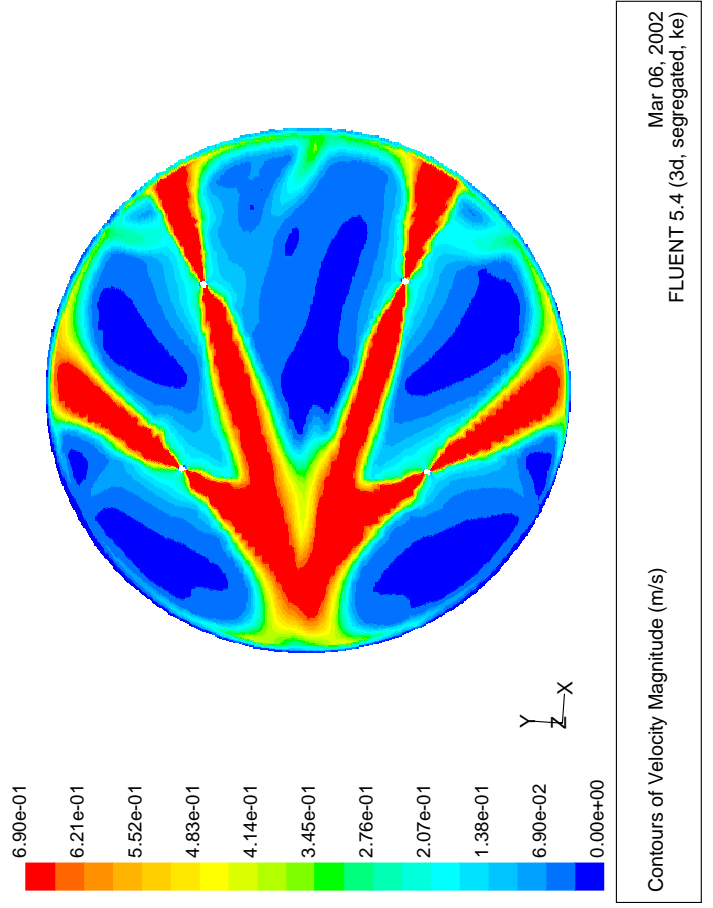

(Flow patterns with no flow obstructions)

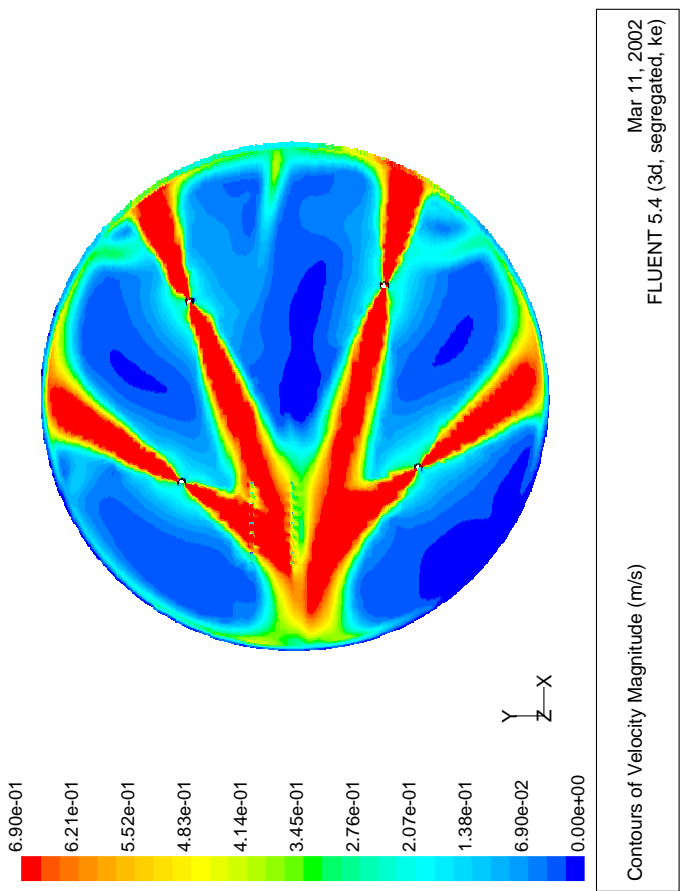

(Flow patterns with flow obstructions)

$(0.69 \mathrm{~m} / \mathrm{sec}=2.27 \mathrm{ft} / \mathrm{sec})$

Figure 14. Comparison of flow patterns at the inlet nozzle plane between without and with flow obstructions under the operating conditions of four slurry pumps. 

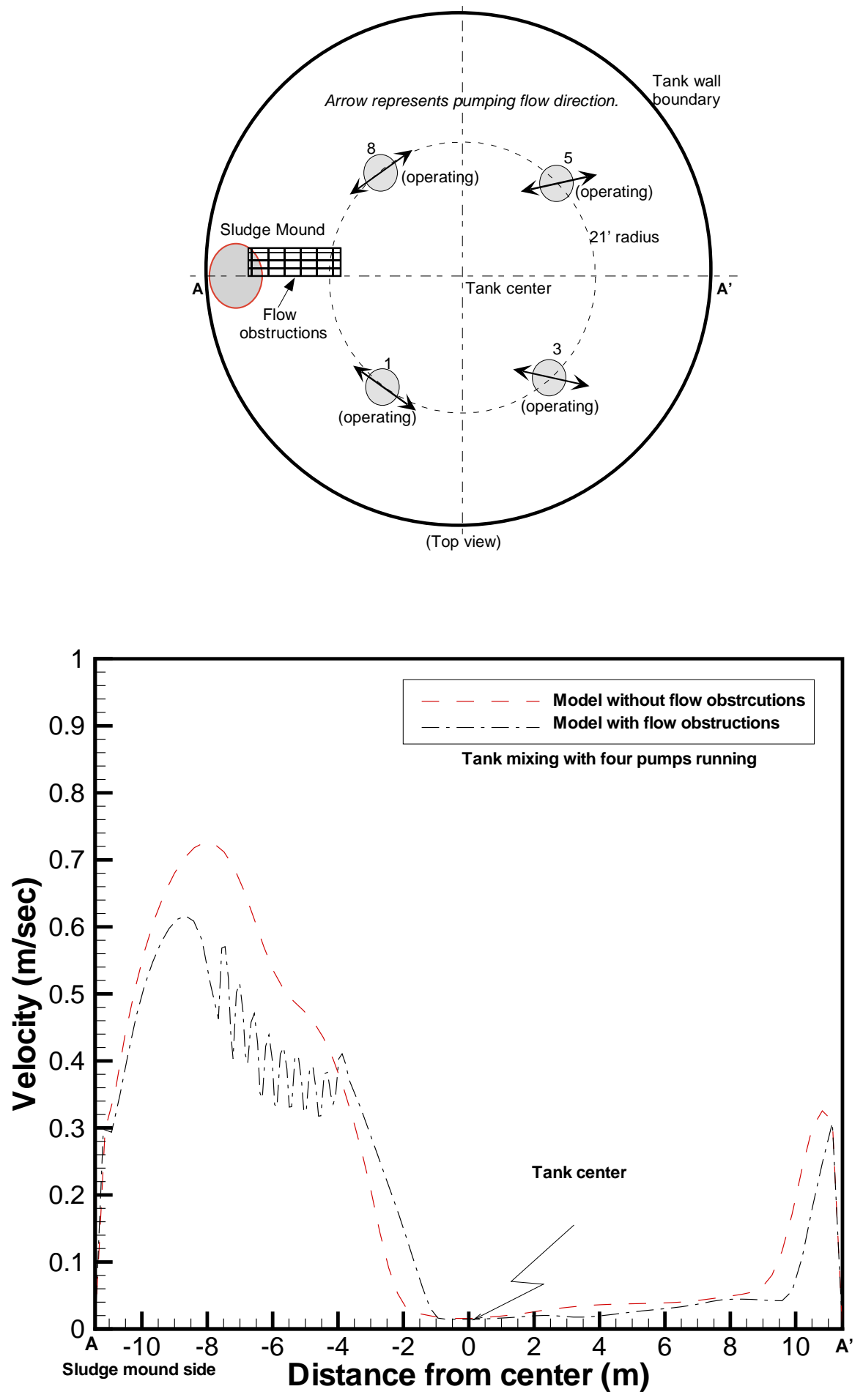

$(1 \mathrm{~m} / \mathrm{sec}=3.28 \mathrm{ft} / \mathrm{sec})$

Figure 15. Comparison of flow velocities along the line A-A' between the models with and without flow obstructions under the operating conditions of four slurry pumps. 
Date: $\quad 01 / 10 / 03$

Page: $\quad 36$ of 58
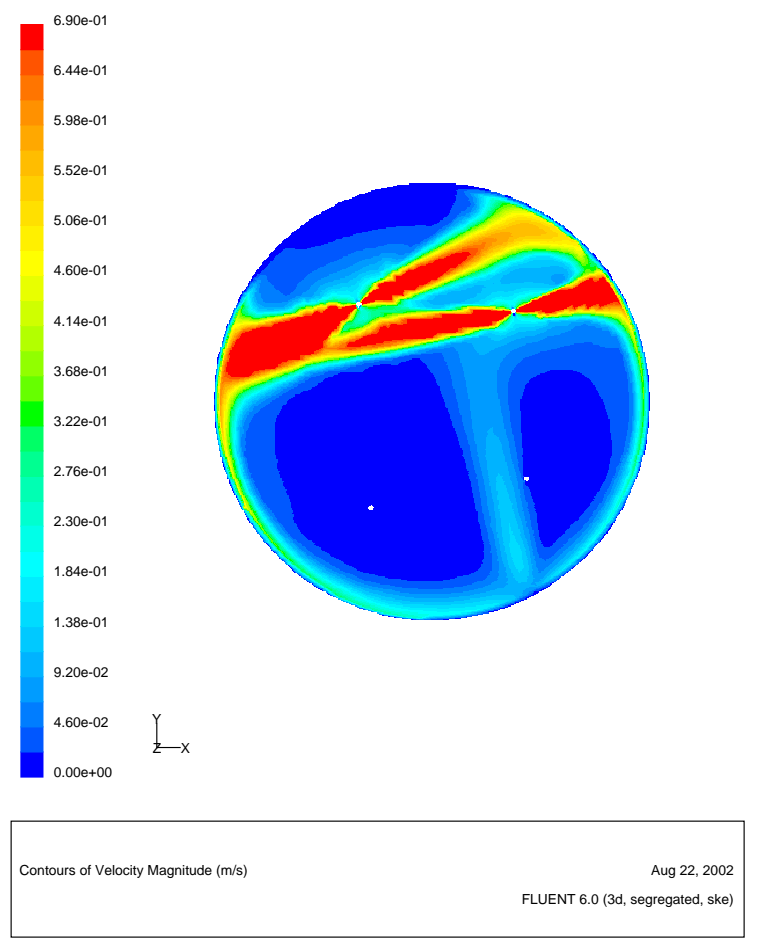

(Flow patterns under 130 in liquid level)
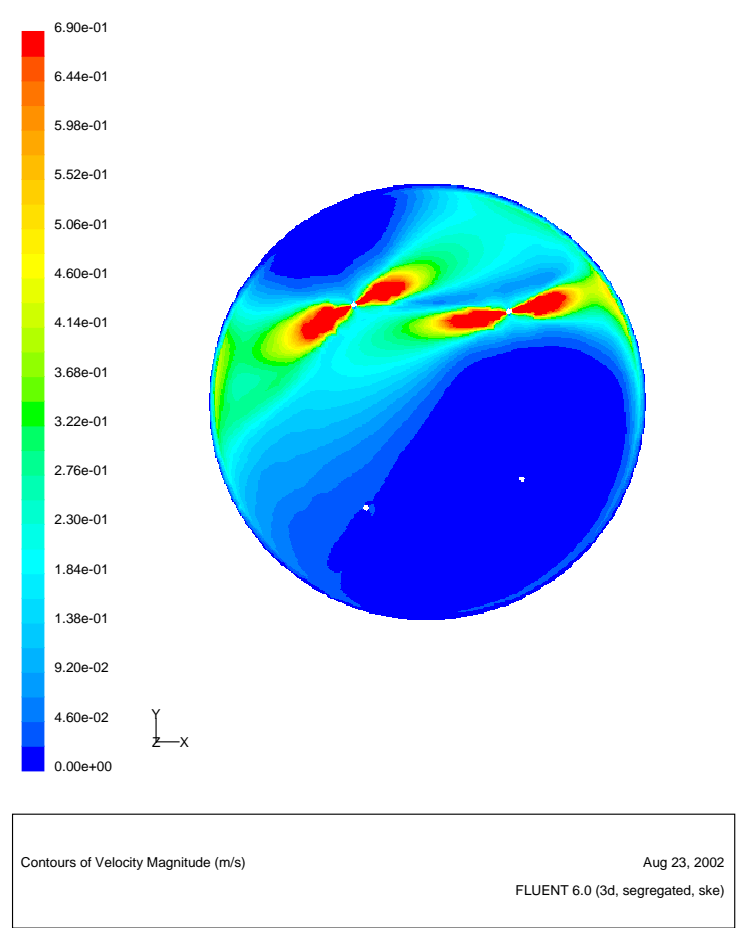

(Flow patterns under 40 in liquid level)

$(0.69 \mathrm{~m} / \mathrm{sec}=2.27 \mathrm{ft} / \mathrm{sec})$

Figure 16. Comparison of flow patterns at the nozzle exit plane for the 130 in and 40 in tank levels under the operating conditions of two slurry pumps. 

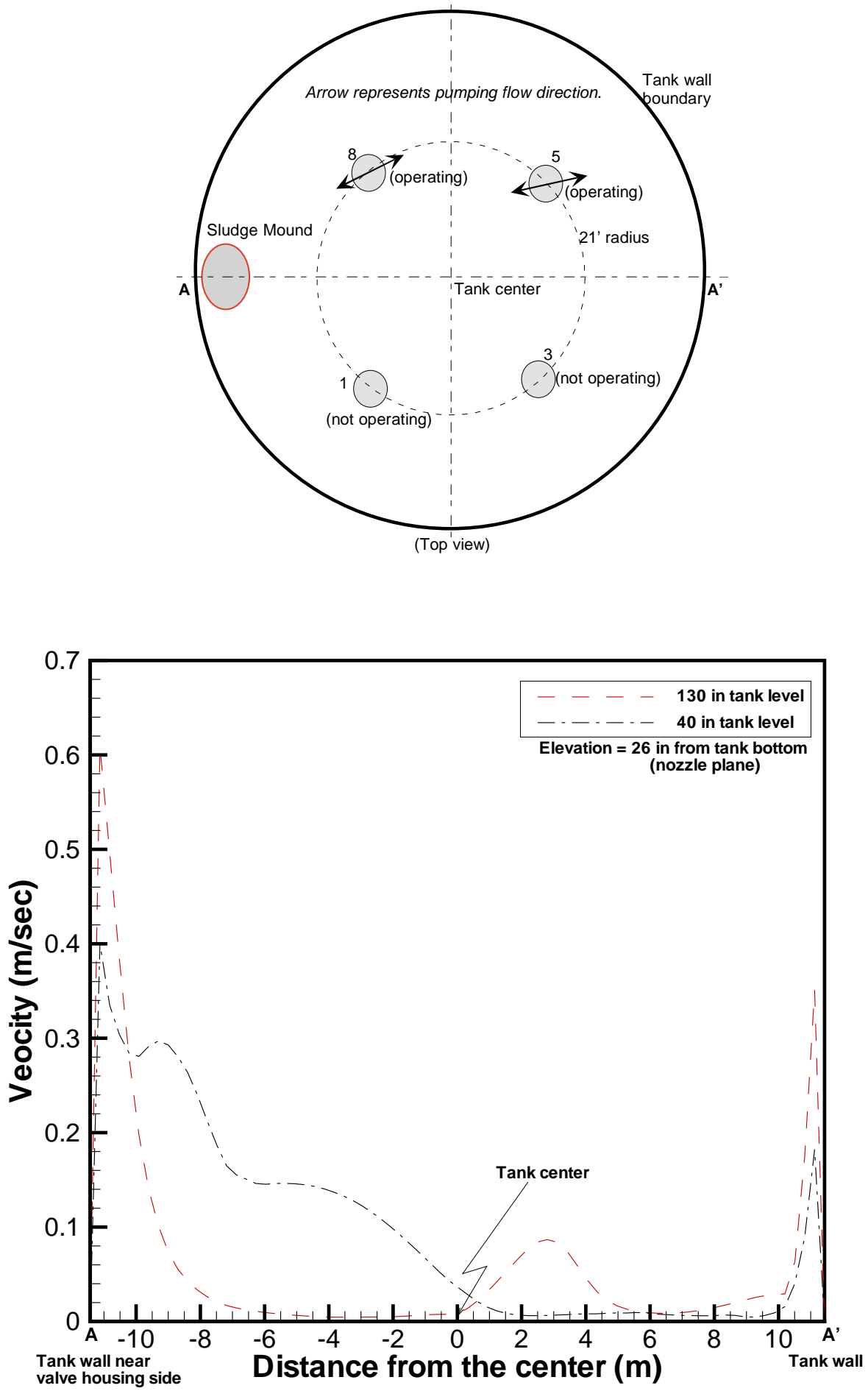

$(1 \mathrm{~m} / \mathrm{sec}=3.28 \mathrm{ft} / \mathrm{sec})$

Figure 17. Comparison of flow velocities along the line A-A' at the nozzle inlet plane between the 130 in and 40 in tank levels under the operating conditions of two slurry pumps. 
Report: WSRC-TR-2002-00460

Date: $\quad 01 / 10 / 03$

Page: $\quad 38$ of 58
WESTINGHOUSE SAVANNAH RIVER COMPANY

HEEL REMOVAL ANALYSIS FOR MIXING PUMPS OF TANK 8
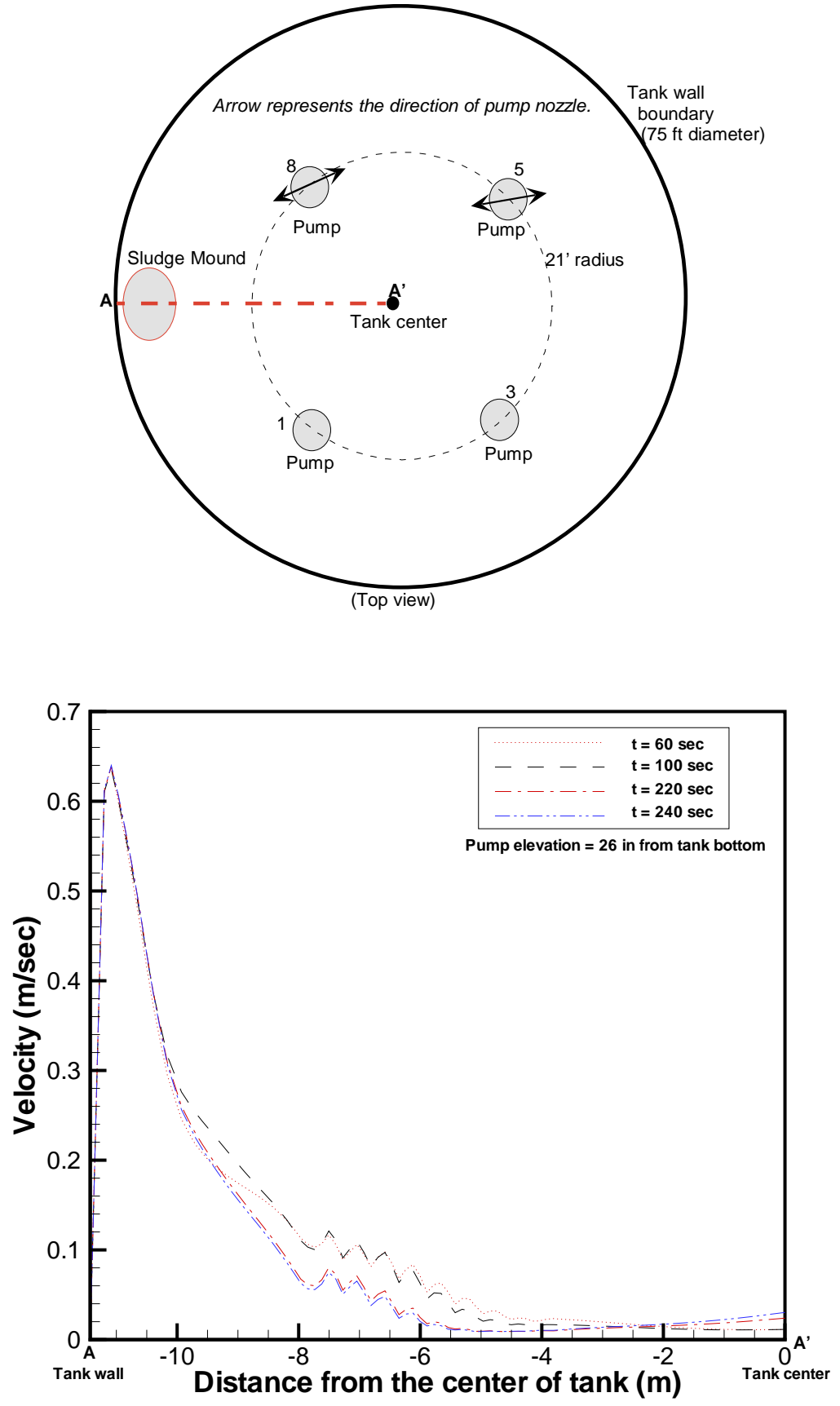

$(1 \mathrm{~m} / \mathrm{sec}=3.28 \mathrm{ft} / \mathrm{sec})$

Figure 17a. Transient flow velocities along the line A'-A at the nozzle inlet plane using Model-I with two pumps running under the reference operating conditions. 

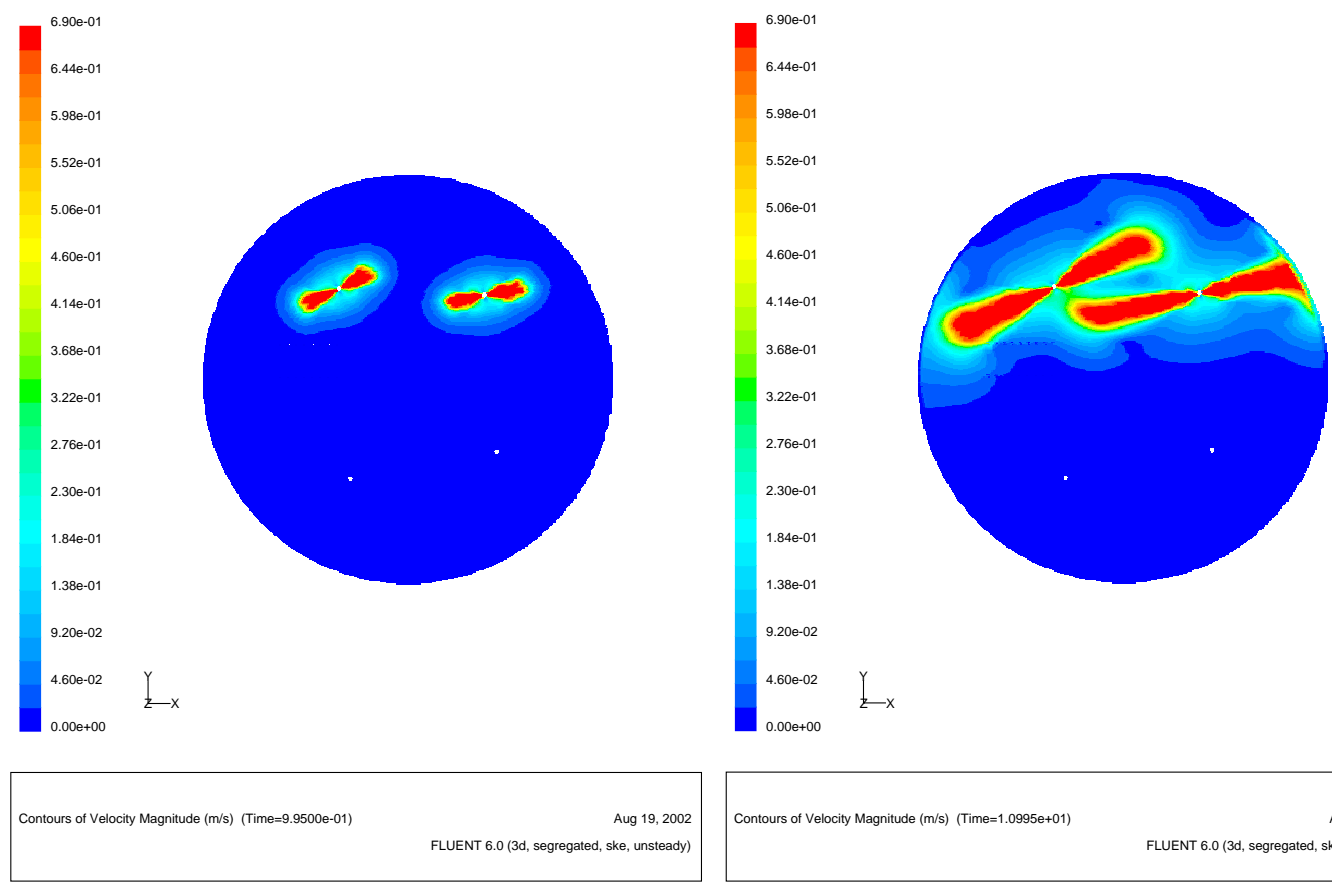

$(\mathrm{t}=1.0 \mathrm{sec})$
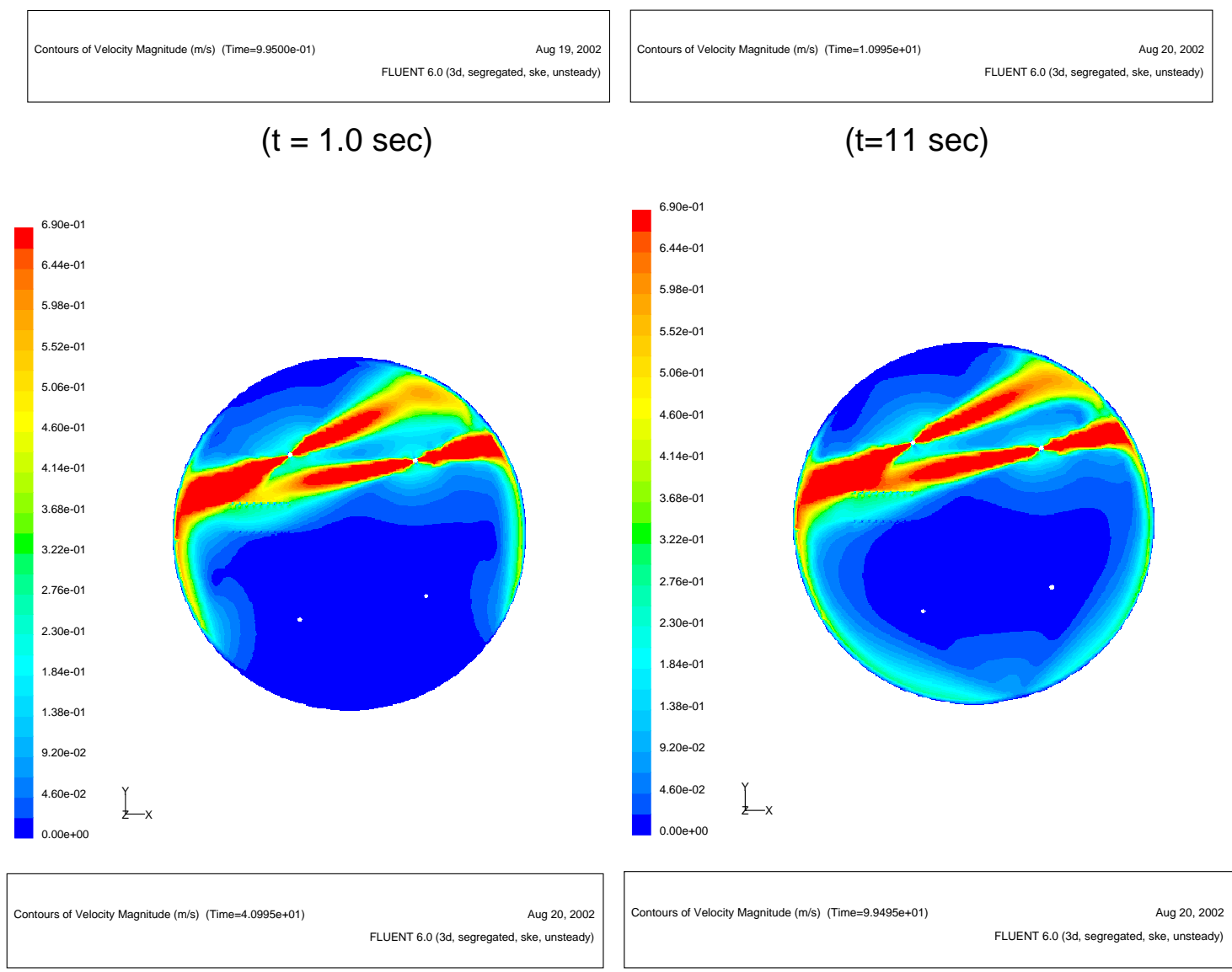

$(\mathrm{t}=41 \mathrm{sec})$

$(0.69 \mathrm{~m} / \mathrm{sec}=2.27 \mathrm{ft} / \mathrm{sec})$

$(\mathrm{t}=100 \mathrm{sec})$

Figure 18. Transient flow evolutions at the nozzle exit plane under the operating conditions of two slurry pumps (pump no. 5 and 8) (continued). 
Report: WSRC-TR-2002-00460

Date: $\quad 01 / 10 / 03$

Page: $\quad 40$ of 58
WESTINGHOUSE SAVANNAH RIVER COMPANY

HEEL REMOVAL ANALYSIS FOR MIXING PUMPS OF TANK 8
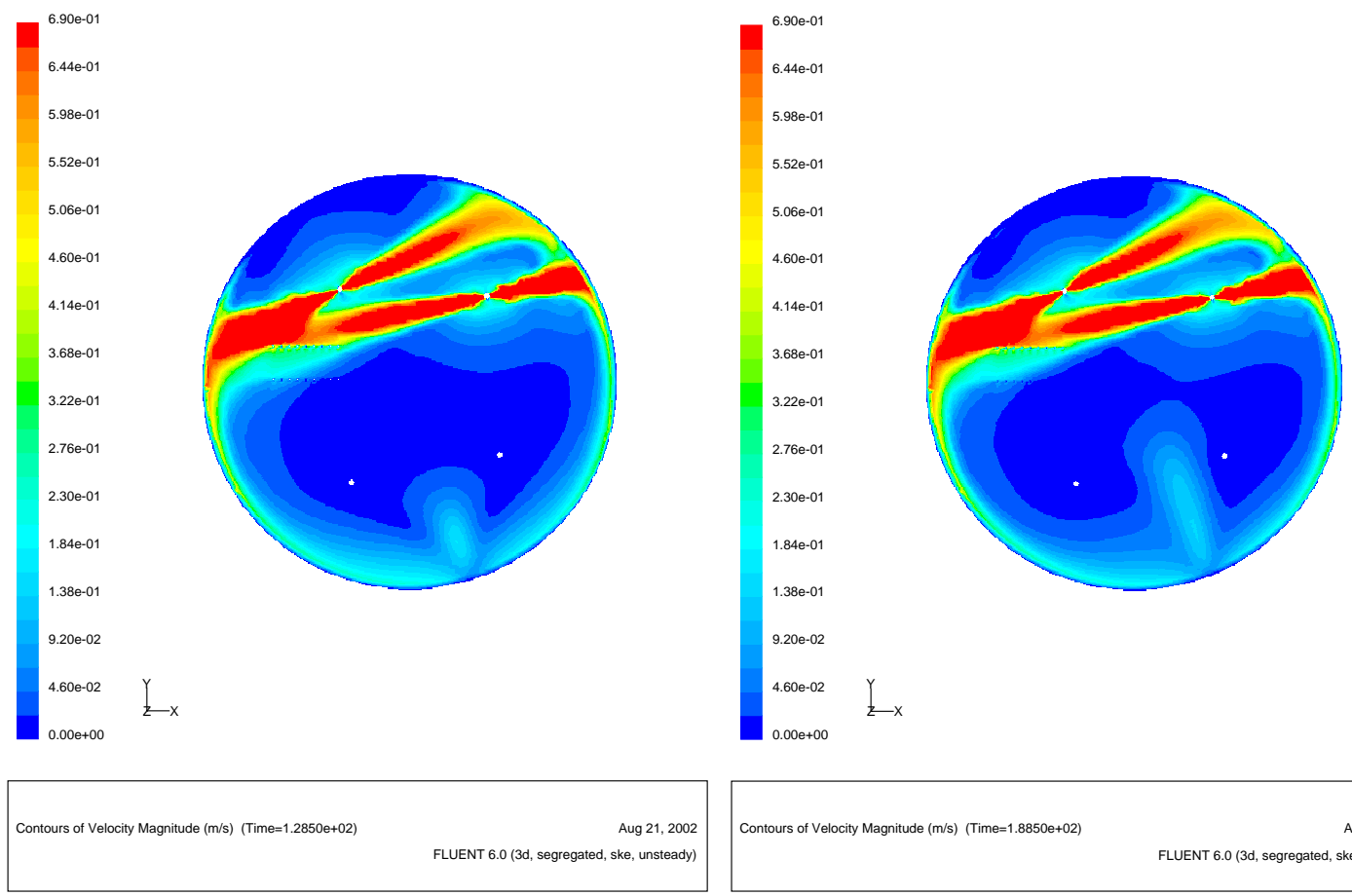

$(\mathrm{t}=130 \mathrm{sec})$

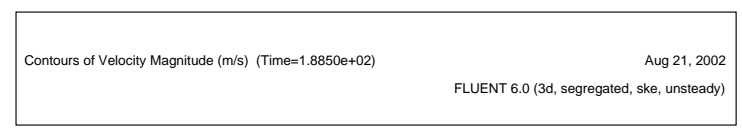

$$
(t=130 \text { sec })
$$

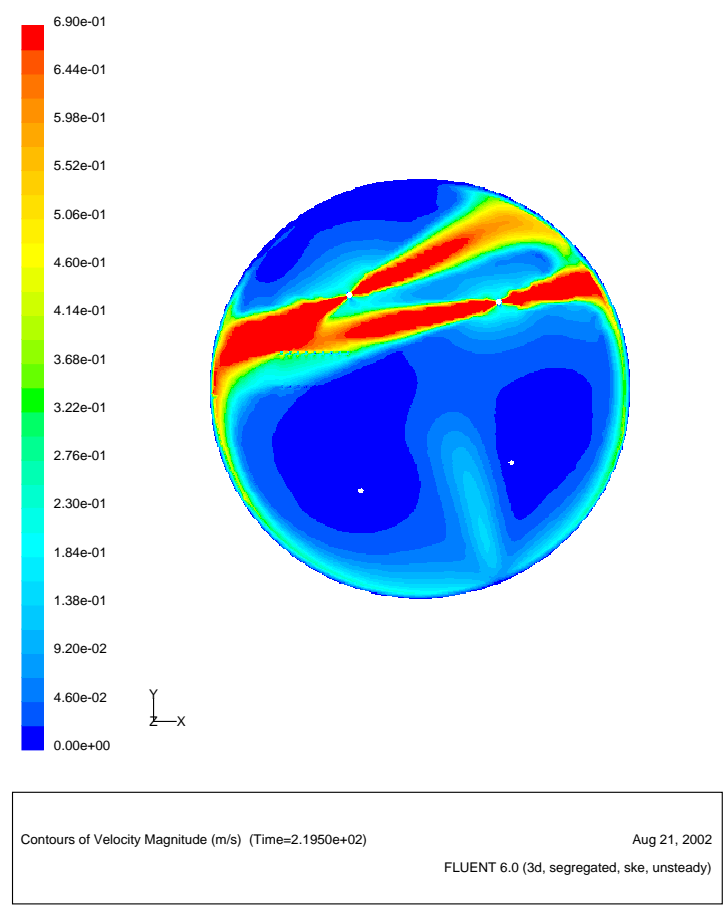

$(\mathrm{t}=220 \mathrm{sec})$

$$
(0.69 \mathrm{~m} / \mathrm{sec}=2.27 \mathrm{ft} / \mathrm{sec})
$$

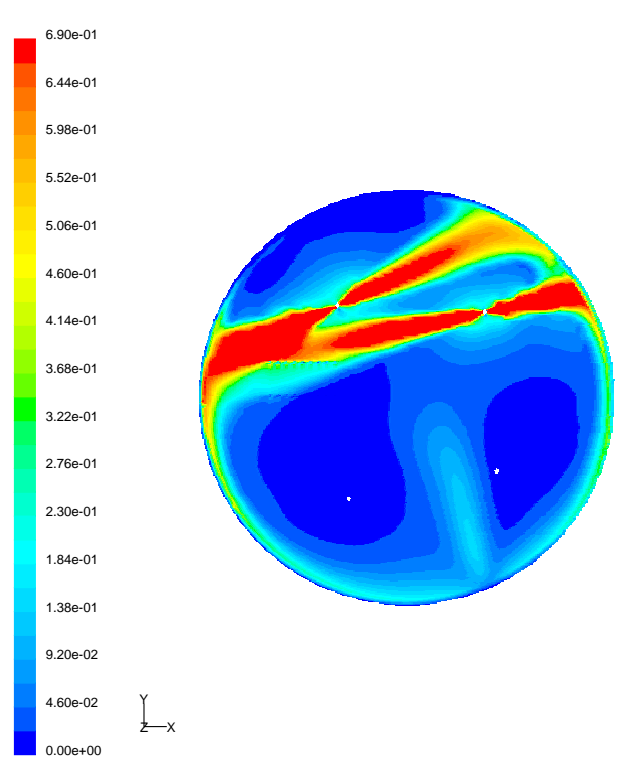

$\sum_{x}$

Figure 18. Transient flow evolutions at the nozzle exit plane under the operating conditions of two slurry pumps (pump no. 5 and 8 ). 


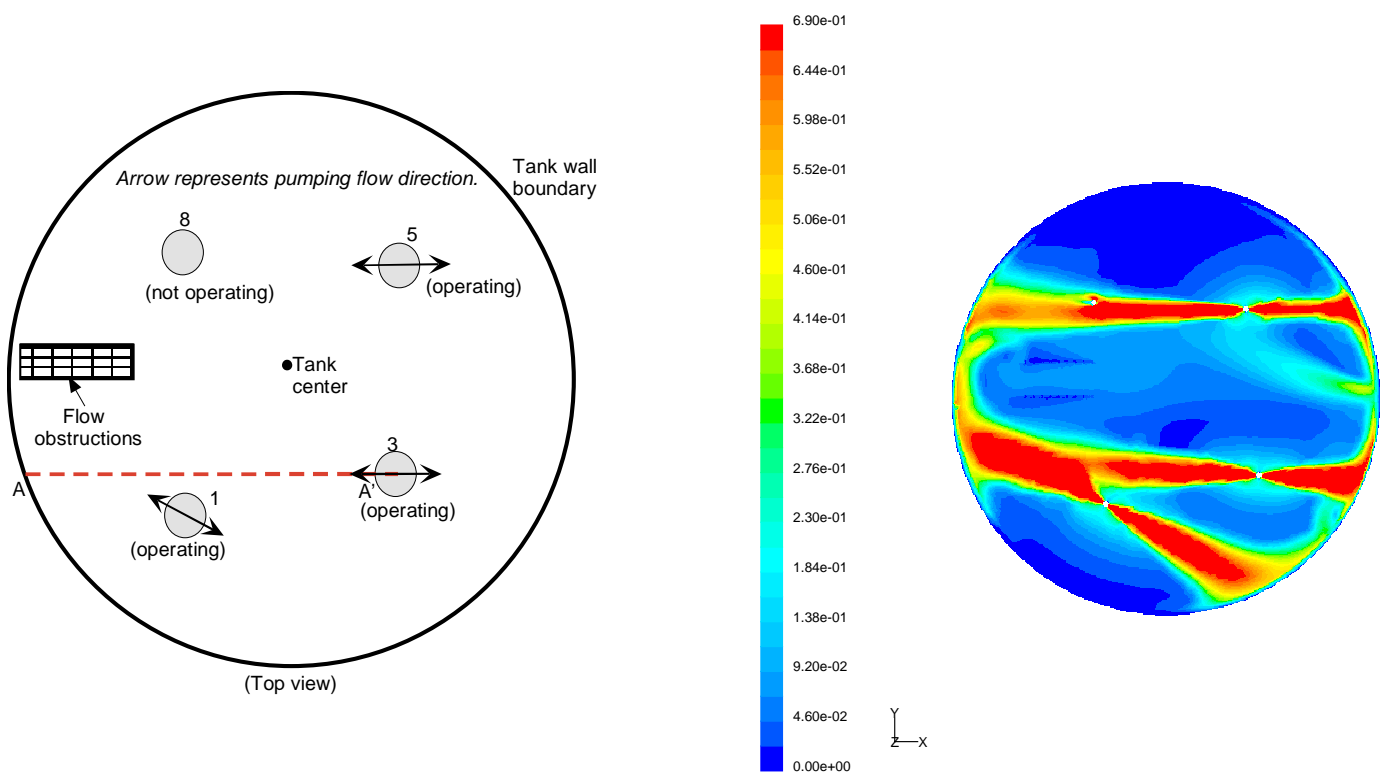

(Orientations of pump operations)

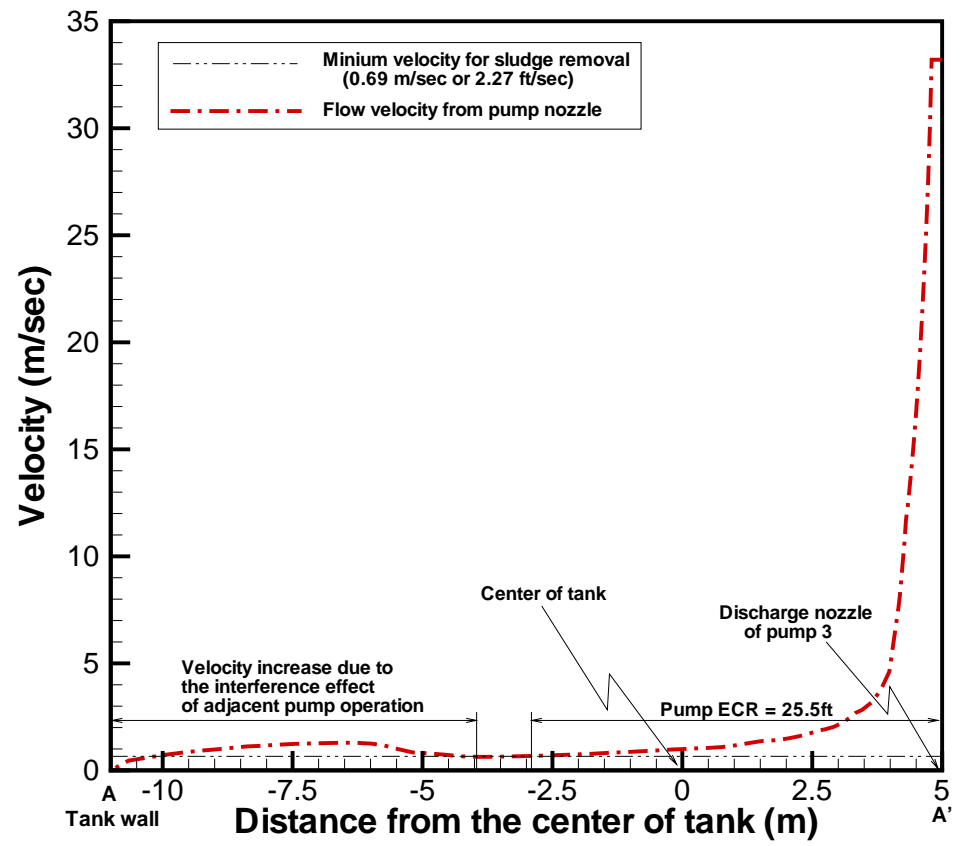

(Flow velocity along the line $A^{\prime}-A$ of pump discharge direction)

$$
(0.69 \mathrm{~m} / \mathrm{sec}=2.27 \mathrm{ft} / \mathrm{sec})
$$

Figure 19. Flow velocity magnitude along the line $A^{\prime}-A$ and pump ECR estimation under three pump operations (pump no. 1, no. 3, and no. 5) 
Date: $\quad 01 / 10 / 03$

Page: $\quad 42$ of 58

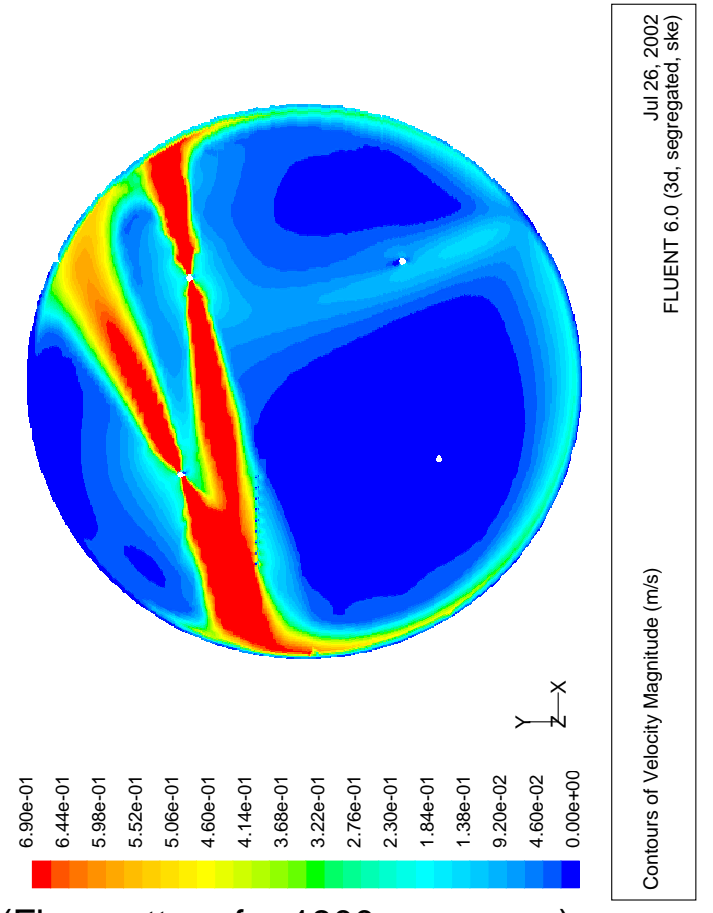

(Flow pattern for 1800 rpm pump)

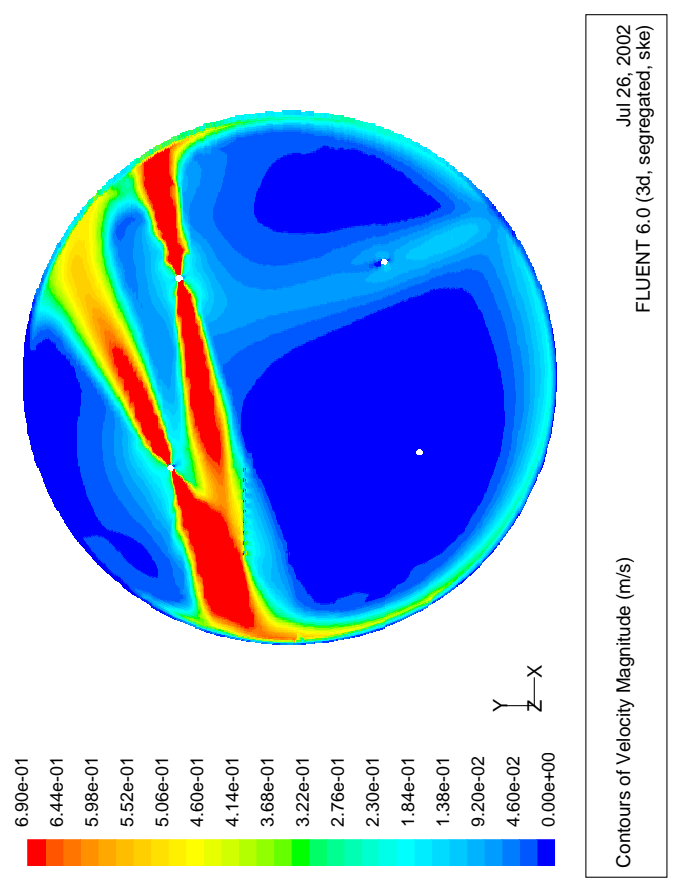

(Flow pattern for 1600 rpm pump)

$(0.69 \mathrm{~m} / \mathrm{sec}=2.27 \mathrm{ft} / \mathrm{sec})$

Figure 20. Comparison of flow patterns at the nozzle inlet plane between two different pump speeds (1800 rpm and $1600 \mathrm{rpm}$ ) using the models with flow obstructions under the operating conditions of two slurry pumps. 

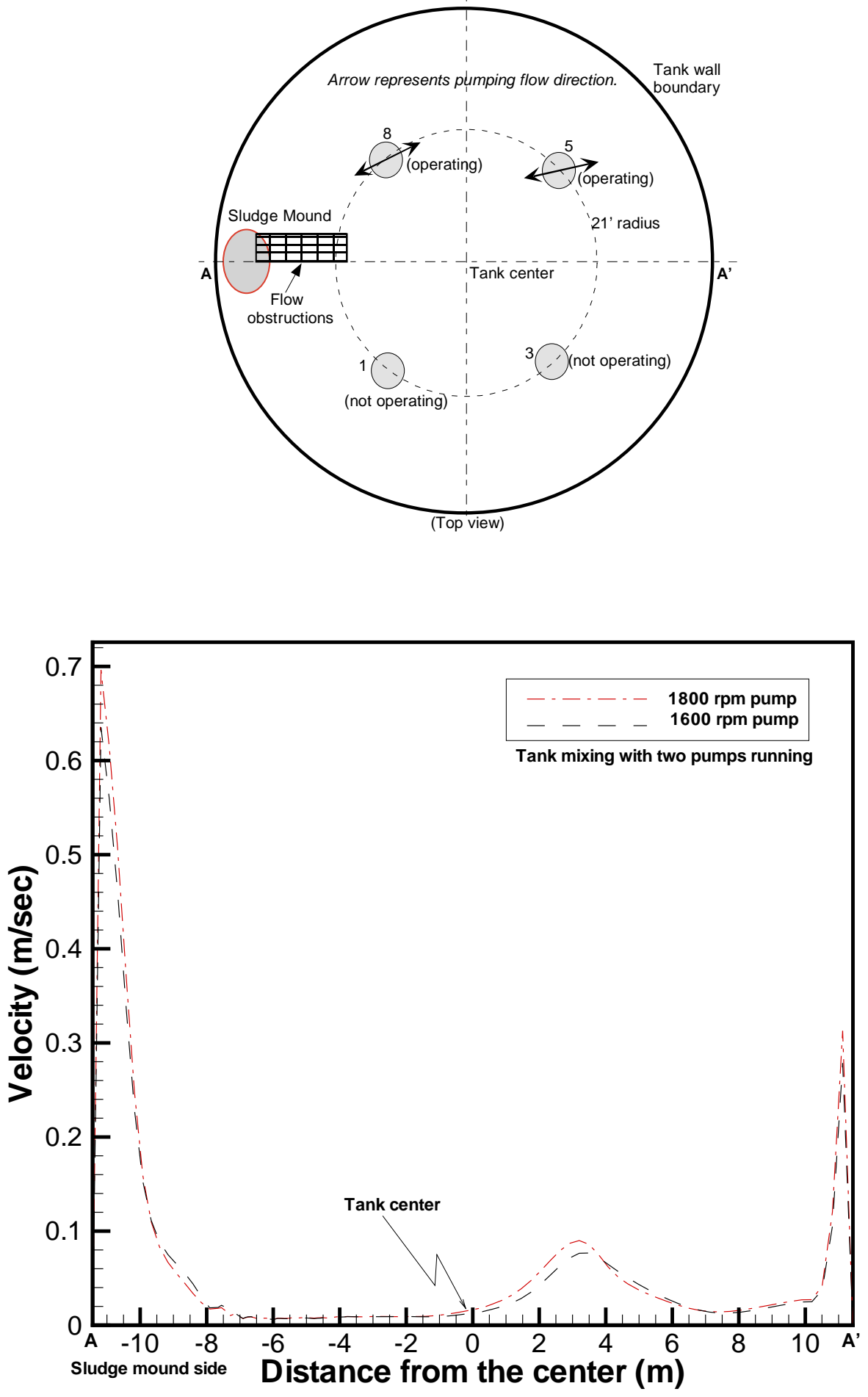

$(1 \mathrm{~m} / \mathrm{sec}=3.28 \mathrm{ft} / \mathrm{sec})$

Figure 21. Comparison of flow velocities along the line A-A' between two different pump speeds (1800 rpm and $1600 \mathrm{rpm}$ ) using the models with flow obstructions under the operating conditions of two slurry pumps. 
Report: WSRC-TR-2002-00460

Date: $\quad 01 / 10 / 03$

Page: $\quad 44$ of 58

\section{WESTINGHOUSE SAVANNAH RIVER COMPANY}

HEEL REMOVAL ANALYSIS FOR MIXING PUMPS OF TANK 8
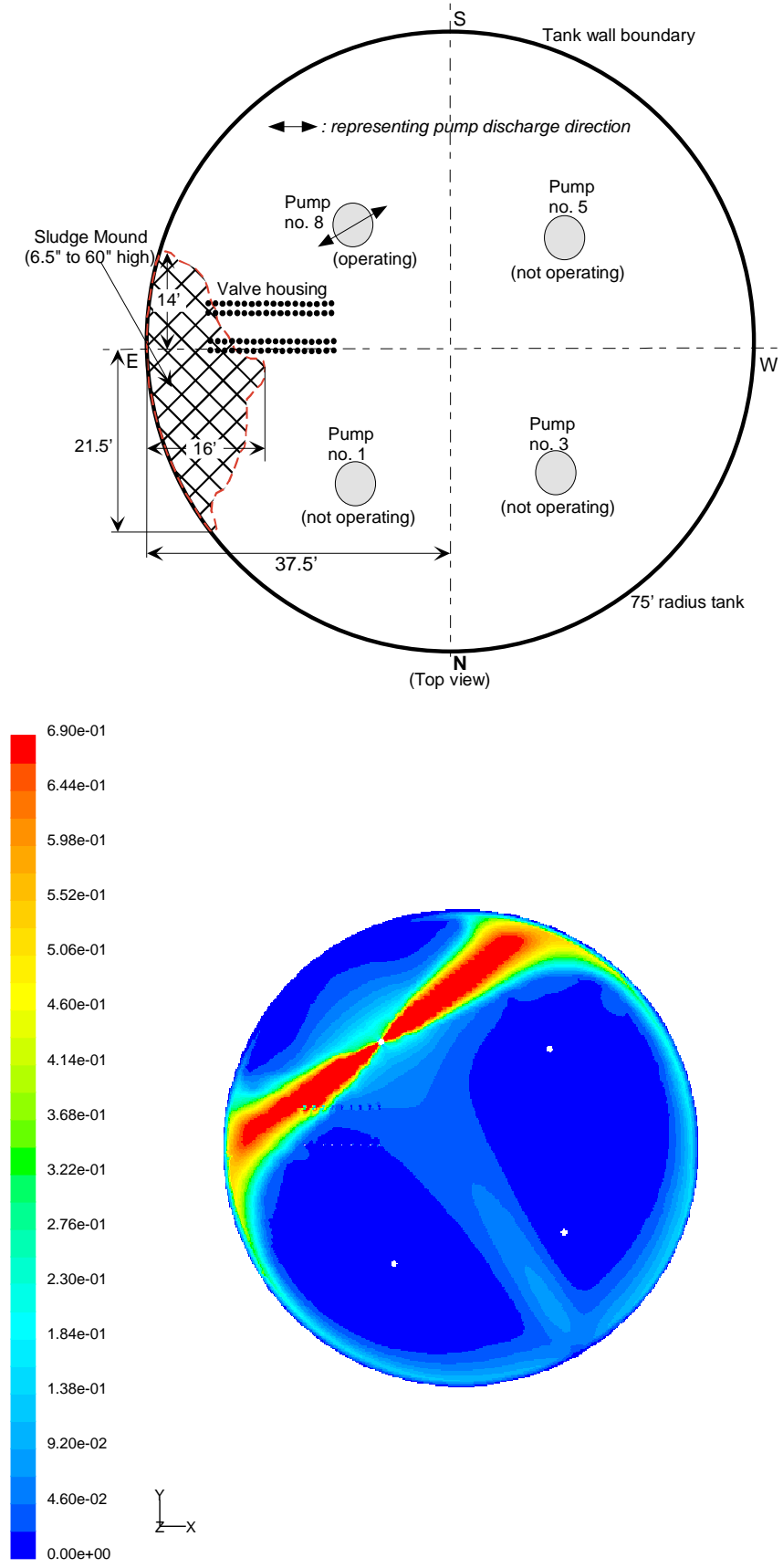

Contours of Velocity Magnitude $(\mathrm{m} / \mathrm{s})$

Aug 30, 2002

FLUENT 6.0 (3d, segregated, ske)

$$
(0.69 \mathrm{~m} / \mathrm{sec}=2.27 \mathrm{ft} / \mathrm{sec})
$$

Figure 22. Flow patterns for the pump orientation of one pump operation in association with effectiveness of sludge removal located at the corner of valve housing (Case-A: pump no. 8 operation) 

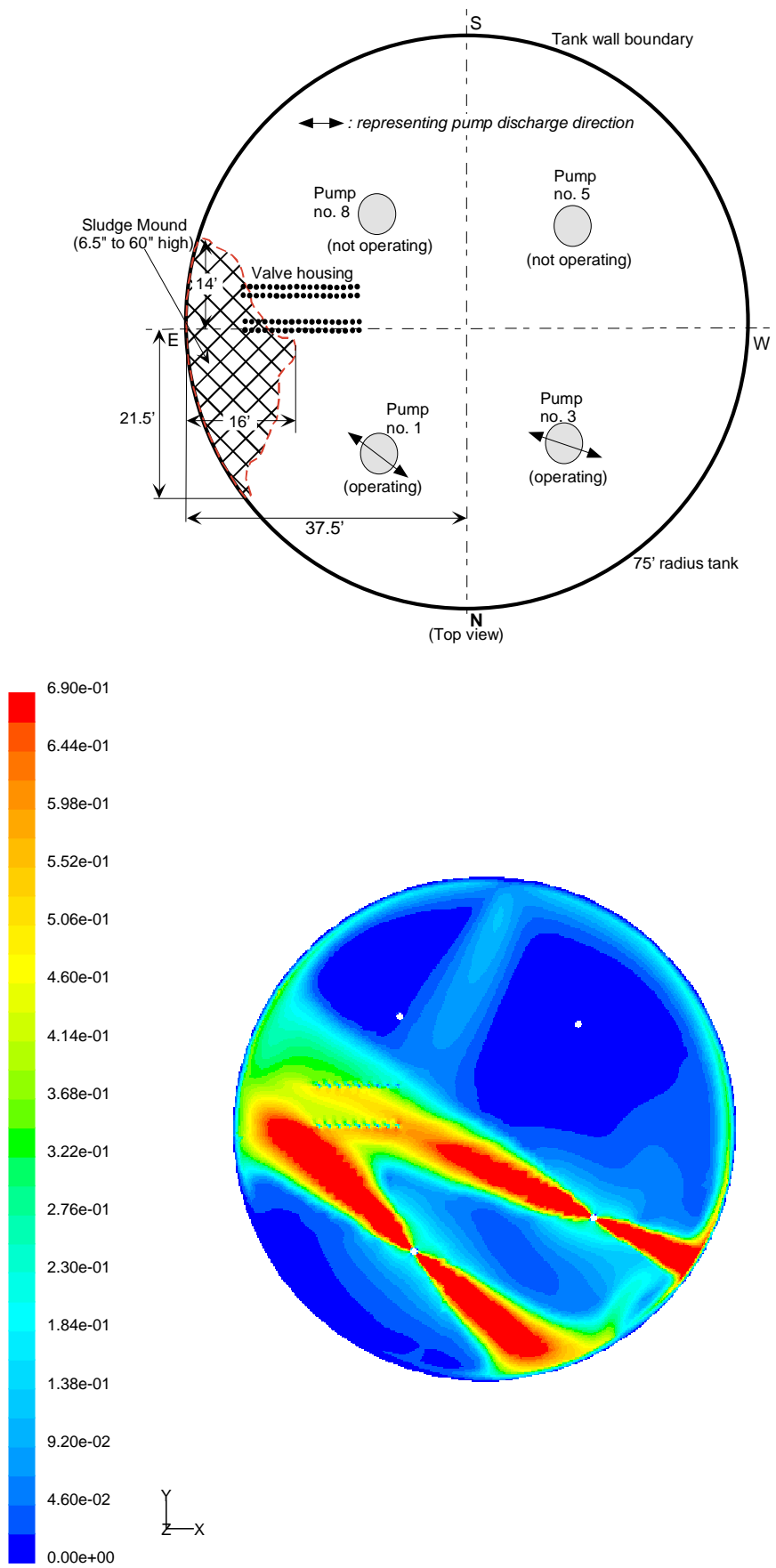

$$
(0.69 \mathrm{~m} / \mathrm{sec}=2.27 \mathrm{ft} / \mathrm{sec})
$$

Figure 23. Flow patterns for the pump orientation of two-pump operation in association with effectiveness of sludge removal located at the corner of valve housing (Case-B: pump no. 1 and no. 3 operations) 
Report: WSRC-TR-2002-00460

Date: $\quad 01 / 10 / 03$

Page: $\quad 46$ of 58
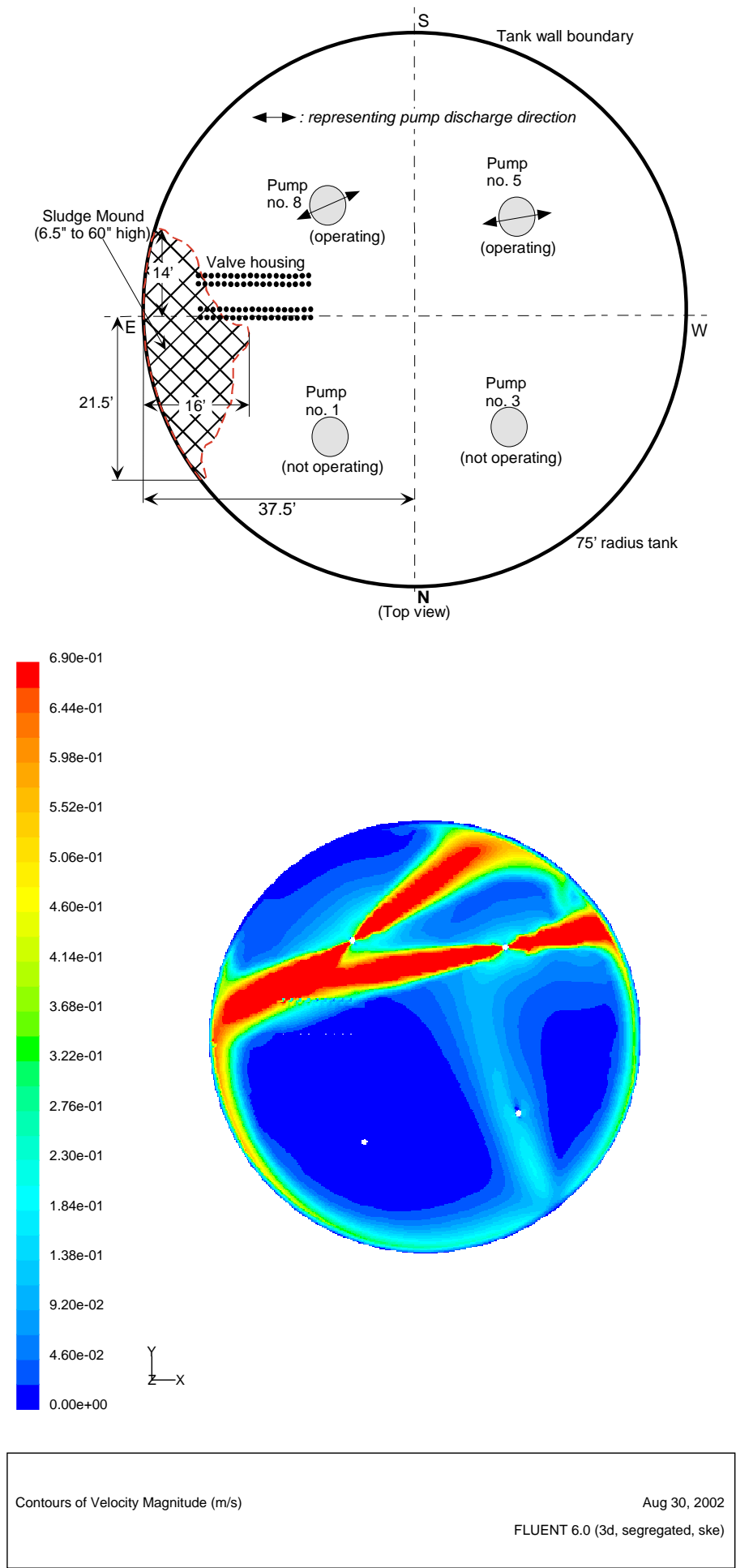

$(0.69 \mathrm{~m} / \mathrm{sec}=2.27 \mathrm{ft} / \mathrm{sec})$

Figure 24. Flow patterns for the pump orientation of two-pump operation in association with effectiveness of sludge removal located at the corner of valve housing (Case-C: pump no. 5 and no. 8 operations) 

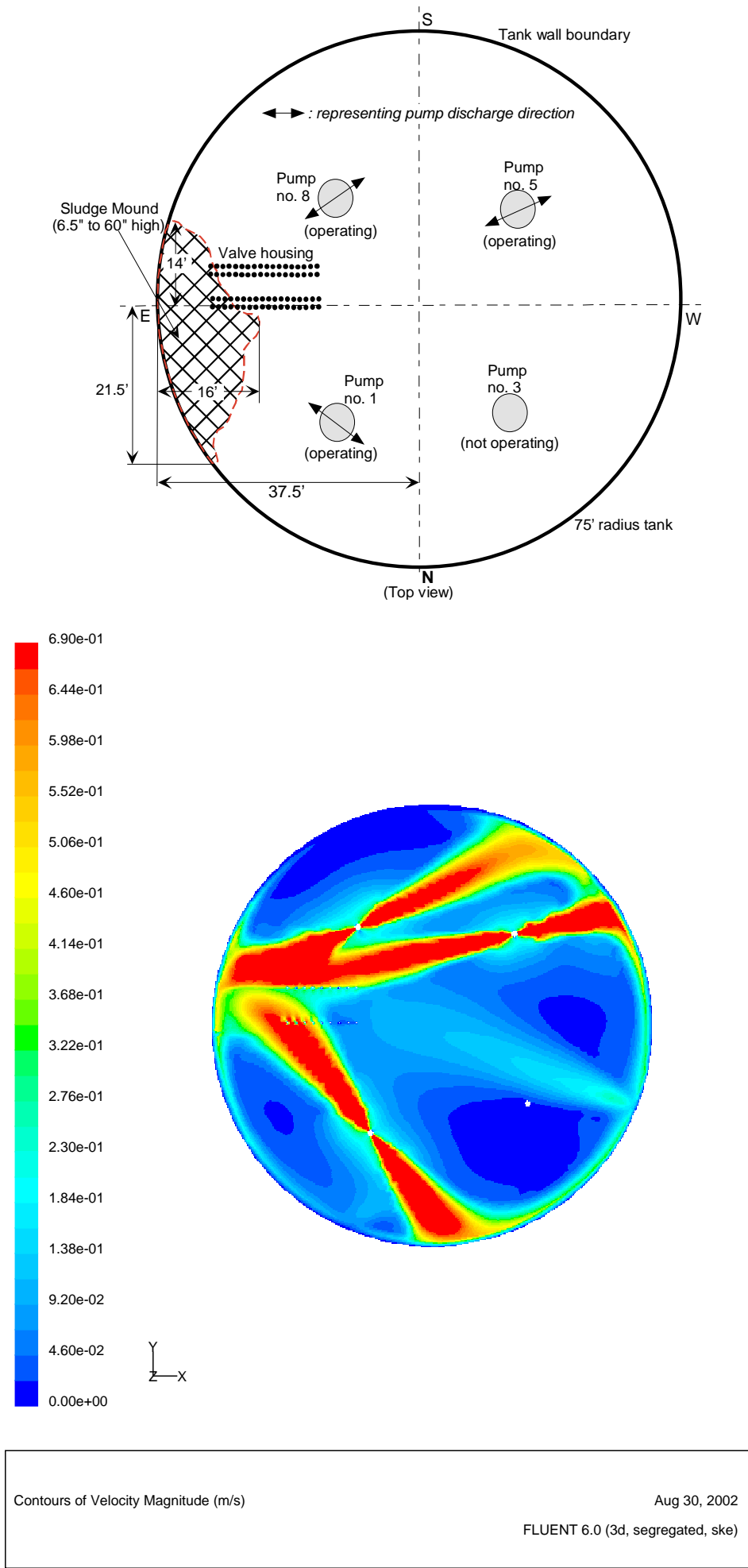

$(0.69 \mathrm{~m} / \mathrm{sec}=2.27 \mathrm{ft} / \mathrm{sec})$

Figure 25. Flow patterns for the pump orientation of three-pump operation in association with effectiveness of sludge removal located at the corner of valve housing (Case-D: pump no. 1, no. 5, and no. 8 operations) 
Page: $\quad 48$ of 58
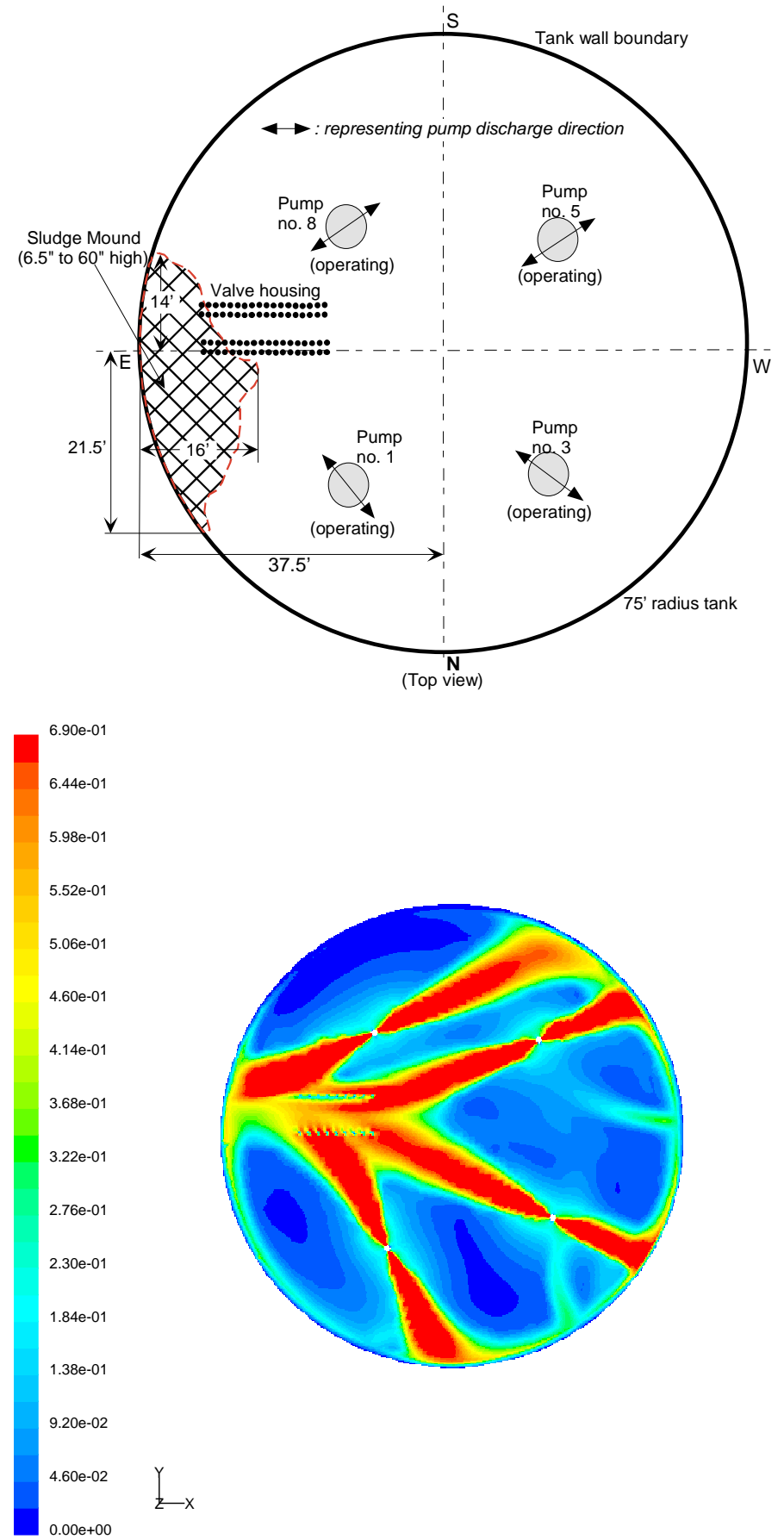

FLUENT 6.0 (3d, segregated, ske)

$$
(0.69 \mathrm{~m} / \mathrm{sec}=2.27 \mathrm{ft} / \mathrm{sec})
$$

Figure 26. Velocity contour plot for the four-pump operation in association with effectiveness of sludge removal located at the corner of valve housing (Case-E: pump no. 1, no. 3, no. 5, and no. 8 operations) 

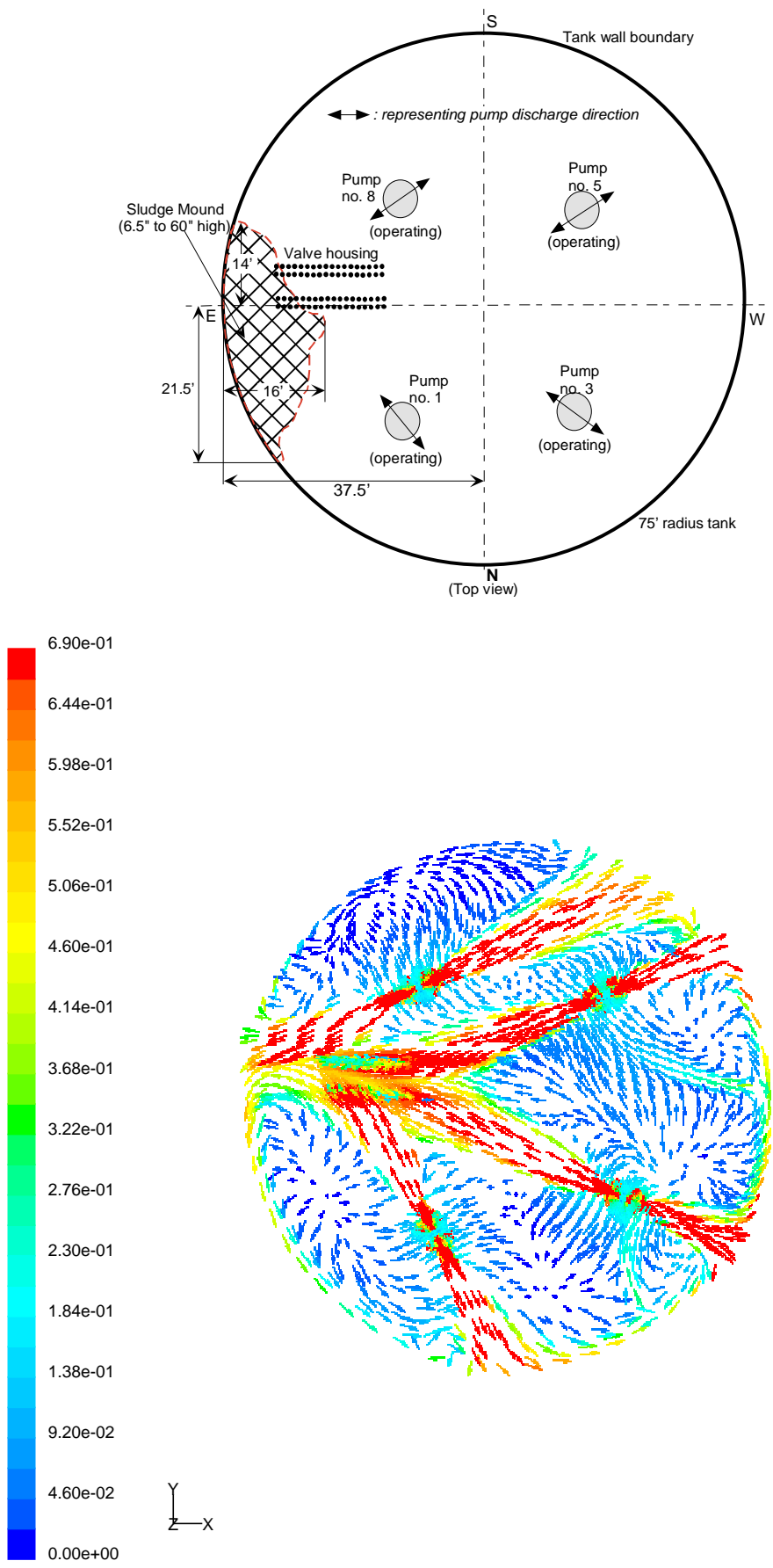

Velocity Vectors Colored By Velocity Magnitude $(\mathrm{m} / \mathrm{s})$

Sep 09, 2002

FLUENT 6.0 (3d, segregated, ske)

$$
(0.69 \mathrm{~m} / \mathrm{sec}=2.27 \mathrm{ft} / \mathrm{sec})
$$

Figure 26a. Flow patterns for the four-pump operation in association with effectiveness of sludge removal located at the corner of valve housing (Case-E: pump no. 1 , no. 3 , no. 5 , and no. 8 operations) 
Report: WSRC-TR-2002-00460

Date: $\quad 01 / 10 / 03$

Page: $\quad 50$ of 58
WESTINGHOUSE SAVANNAH RIVER COMPANY

HEEL REMOVAL ANALYSIS FOR MIXING PUMPS OF TANK 8
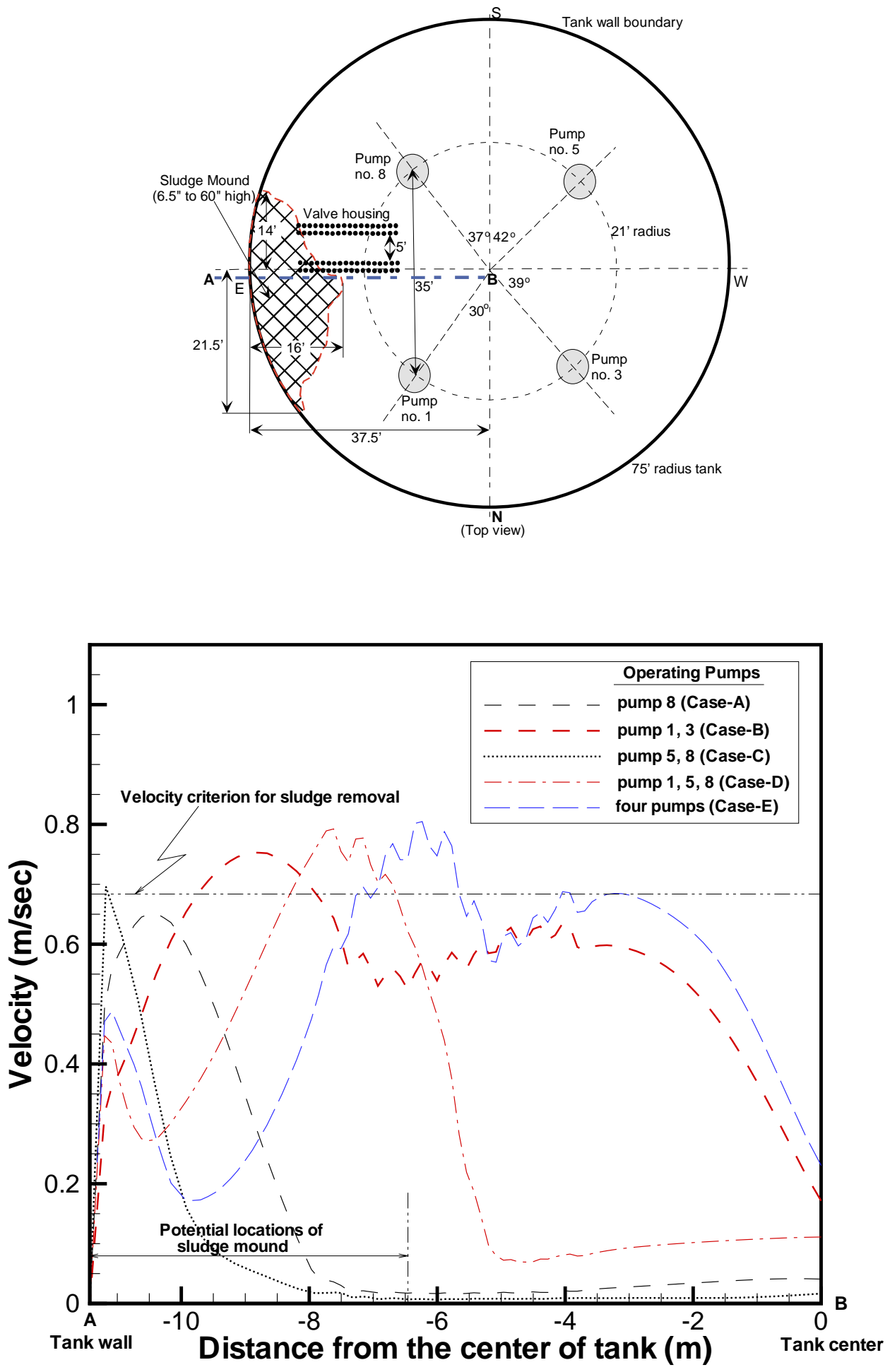

$(0.69 \mathrm{~m} / \mathrm{sec}=2.27 \mathrm{ft} / \mathrm{sec})$

Figure 27. Flow velocity results along the line $A-B$ near the sludge heel regions using selected numbers of operating pumps and aiming nozzle directions for the reference operating conditions (1800 rpm) 

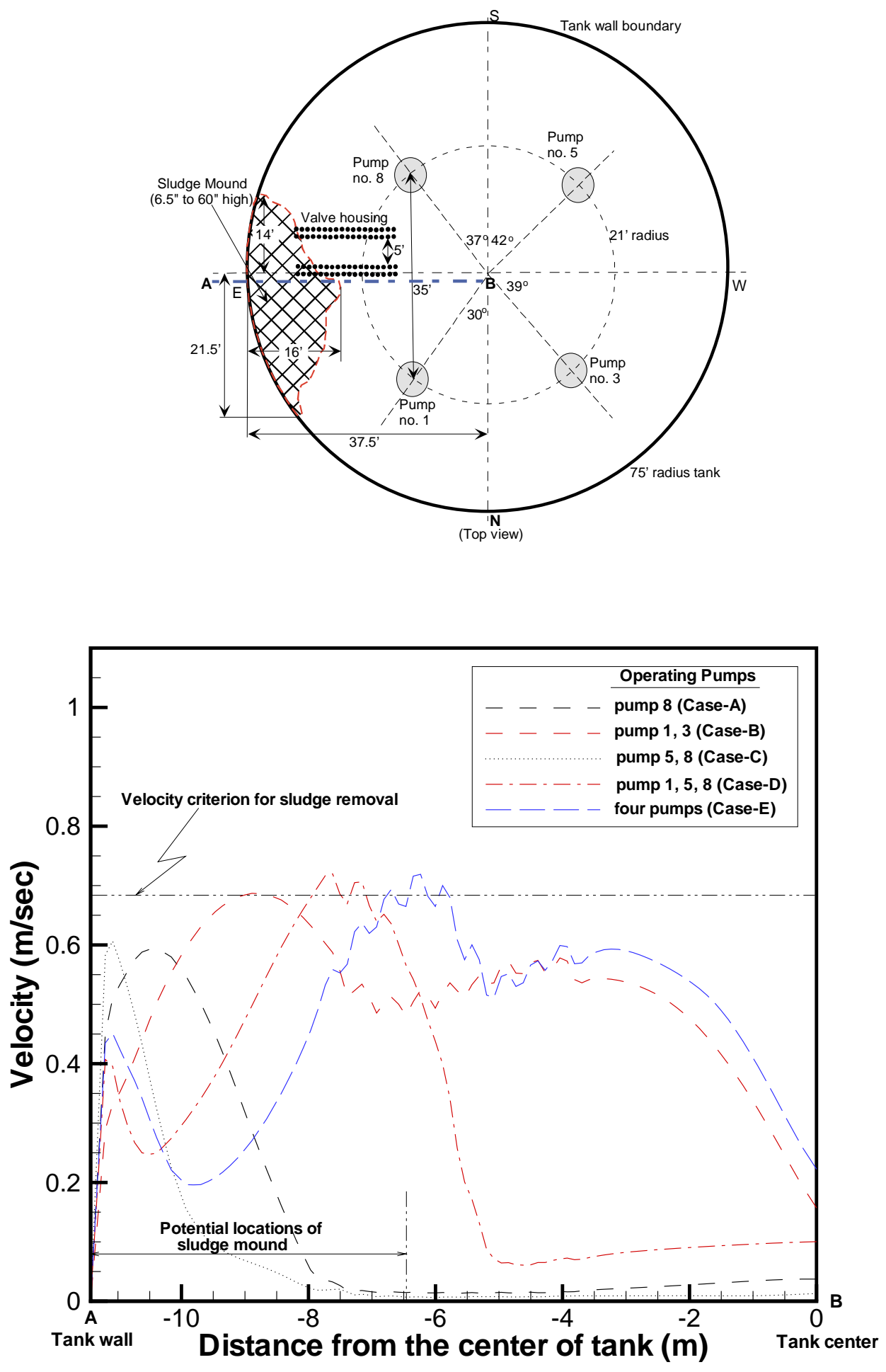

$(0.69 \mathrm{~m} / \mathrm{sec}=2.27 \mathrm{ft} / \mathrm{sec})$

Figure 28. Flow velocity results along the line A-B near the sludge heel regions using selected numbers of operating pumps and aiming nozzle directions for the lower pump speed (1600 rpm) 
Report: WSRC-TR-2002-00460

Date: $\quad 01 / 10 / 03$

Page: $\quad 52$ of 58
WESTINGHOUSE SAVANNAH RIVER COMPANY

HEEL REMOVAL ANALYSIS FOR MIXING PUMPS OF TANK 8
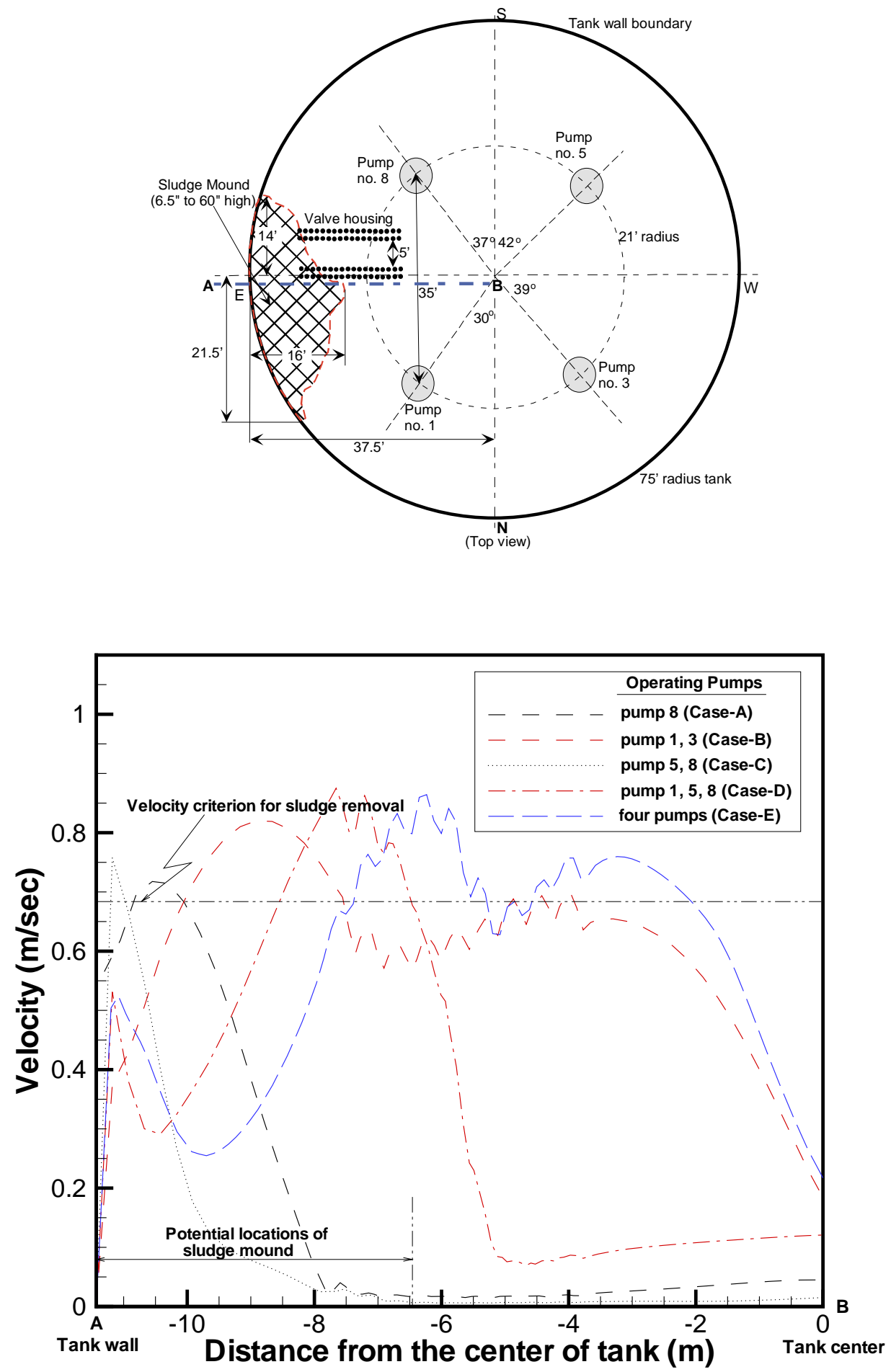

$(0.69 \mathrm{~m} / \mathrm{sec}=2.27 \mathrm{ft} / \mathrm{sec})$

Figure 29. Flow velocity results along the line A-B near the sludge heel regions using selected numbers of operating pumps and aiming nozzle directions for the lower pump speed (2000 rpm) 


\section{Summary and Conclusions}

Tank 8 simulation models with slurry pumps have been developed. Sensitivity calculations have been performed for key operational parameters such as tank liquid level, pump elevation, and pump speed and to provide guidance for sludge heel suspension and removal operations in Tank 8 . Reference design and operating conditions were used as shown in Table 4. In the analysis, the pump was assumed to be stationary since previous results showed that pump rotational effects were negligible. Solid obstructions including the pump housing, the 14" riser, and 72-tube valve housing structure were included in the performance model. Free surface motion of the tank liquid was neglected for high tank liquid level.

Transient and steady-state analyses with a two-equation turbulence model were performed with FLUENT ${ }^{\mathrm{TM}}$, a commercial computational fluid dynamics (CFD) code. All analyses were based on three-dimensional results since a two-dimensional approach could not consider wall dissipation and horizontal vortex terms properly. A recommended operational strategy was developed assuming that local fluid velocity can be used as a measure of sludge suspension and removal. For a minimum suspension velocity of $2.27 \mathrm{ft} / \mathrm{sec}$, the results indicated that the existing slurry mixers running at $1800 \mathrm{rpm}$ could remove the sludge heel from the tank with a 130 in liquid level. A recommended strategy is summarized in Table 6.

The CFD simulation results for the slurry pump showed that steady-state flow patterns were reached in about 220 seconds after starting the pump. As expected, the results also showed that when the tank level was lower, the operational time to reach steadystate conditions was much shorter. In addition, when the pump speed is slower, times to reach steady-state flow patterns are much longer than with the faster pump speed.

The main conclusions are as follows:

- The results show that model prediction for ECR agrees with test data. In the velocity ranges where sludge removal is required, the model provides a conservative estimate when compared to actual test data.

- Internal obstructions can help increase local flow velocity in some regions, such as the valve housing structures where the sludge mound is located in Tank 8 . The results indicate that when the model does not include internal obstructions, local velocities adjacent to the tank wall are somewhat lower than those needed to remove sludge.

- Higher tank level results in better performance for suspending and removing the sludge for the given design and operating conditions of Tank 8.

- When pump speed is lower than $1800 \mathrm{rpm}$, the velocities near the wall region by the sludge mound are probably not high enough to suspend and mobilize the sludge.

- The computational results for two different fluids, water and a typical slurry (1.2 specific gravity, $2 \mathrm{cp}$ ), show that the maximum clearing distance is not sensitive to the slurry fluid properties. Therefore, all the flow pattern results based on water are valid for slurry flow in Tank 8. 
Report: WSRC-TR-2002-00460

Date: $\quad 01 / 10 / 03$

Page: 54 of 58
WESTINGHOUSE SAVANNAH RIVER COMPANY

HEEL REMOVAL ANALYSIS FOR MIXING PUMPS OF TANK 8

(This Page Intentionally Left Blank) 


\section{Recommendation}

The analysis reported here did not actually model the existence of the sludge mound all flow patterns were based on a flat-bottomed tank. Therefore, the recommended pump operation program is based on an assumption that it is best to attack the leading edge of the sludge mound first. With this in mind, the recommended pump operational program is shown in Table 6 and repeated here in the recommended order:
1. Case-A: Pump 8, $38^{\circ}$
2. Case-B: Pump $1,43^{\circ}$
Pump 3, $22^{\circ}$
3. Case-C: Pump 5, $16^{\circ}$
Pump 8, $27^{\circ}$
4. Case-D: Pump $1,54^{\circ}$
Pump 5, $16^{\circ}$
Pump 8, $27^{\circ}$
5. Case-E: Pump $1,65^{\circ}$
Pump 3, $22^{\circ}$
Pump 5, $27^{\circ}$
Pump 8, $27^{\circ}$

Pump orientations are as shown in Figures 22 through 26 . The uncertainty in the minimum sludge suspension velocity becomes an issue for regions close to the wall and a pump speed of $1800 \mathrm{rpm}$. $2000 \mathrm{rpm}$ is expected to do a better job removing sludge, especially close to the tank wall. The required time duration for each case was not studied in this analysis and will likely have to be determined through operational observations. 
Report: WSRC-TR-2002-00460

Date: $\quad 01 / 10 / 03$

Page: 56 of 58
WESTINGHOUSE SAVANNAH RIVER COMPANY

HEEL REMOVAL ANALYSIS FOR MIXING PUMPS OF TANK 8

(This Page Intentionally Left Blank) 


\section{References}

1. Technical Task Request by B. J. Adkins, HLE-TTR-2002-075, Rev. 0, January 24, 2002.

2. E. J. Freed and P. S. Mukherjee, "Tank 8 Waste Rremoval Operating Plan", UESR-F-00009, Rev. 5, April 2001.

3. S. Y. Lee and R. A. Dimenna, "Performance analysis for Mixing Pumps in Tank 18", WSRC-TR-2001-00391 (October 2001).

4. HLW Technical Request Form, HLE-TTR-2001-049, Rev. 1, May 29, 2001.

5. N. V. Chadrasekhara Swamy and P. Bandyopadhyay, "Mean and Turbulence Characteristics of Three-Dimensional Wall Jets", Journal of Fluid Mechanics, Vol. 71, Part 3, pp. 541-562 (1975).

6. FLUENT, Fluent, Inc. (1998).

7. S. Y. Lee and R. A. Dimenna, "Validation Analysis for the Calculation of a Turbulent Free Jet in water Using CFDS-FLOW3D and FLUENT (U)", WSRC-TR95-0170 (May 1995).

8. C. K. Madina and L. P. Bernal of F, "Interaction of a Turbulent Round Jet with the Free surface", Journal of Fluid Mechanics, Vol. 261, pp. 305-332 (1994)

9. Personal Communications with P. S. Mukherjee, March 12, 2002

10. Abramovich, G. N., "The Theory of Turbulent Jets", The MIT Press, Cambridge, MA, 1963.

11. H. Schlichting, Boundary Layer Theory, McGraw-Hill Book Company, New York (1967).

12. W. M. Rohsenow and H. Y. Choi, Heat, Mass, and Momentum Transfer, PrenticeHall, Inc., New Jersey (1961).

13. Graf, W. H., Hydraulics of Sediment Transport, McGraw-Hill Book Company, New York, 1971.

14. H. Tennekes and J. L. Lumley, A First Course in Turbulence, The MIT Press, Cambridge, MA, 1972.

15. B. V. Churnetski, "Effective Cleaning Radius Studies", Memorandum, DPST-81282, February 19, 1981.

16. J. H. Perry, Chemical Engineers' Handbook, Fourth Edition, McGraw-Hill Book Co, New York. 
Report: WSRC-TR-2002-00460

Date: $\quad 01 / 10 / 03$

Page: $\quad 58$ of 58
WESTINGHOUSE SAVANNAH RIVER COMPANY

HEEL REMOVAL ANALYSIS FOR MIXING PUMPS OF TANK 8

(This Page Intentionally Left Blank) 